\title{
HIGH GEOTHERMAL ENERGY UTILIZATION GEOTHERMAL/FOSSIL HYBRID POWER CYCLE:- A PRELIMINARY INVESTIGATION
}

November 1978

\section{Ramon L. Grijalva}

Stanley K. Sanemitsu

Prepared for the

United States Department of Energy

Division of Geothermal Energy

under grant extension no. EG-77-G-03-1572

Prime contractor:

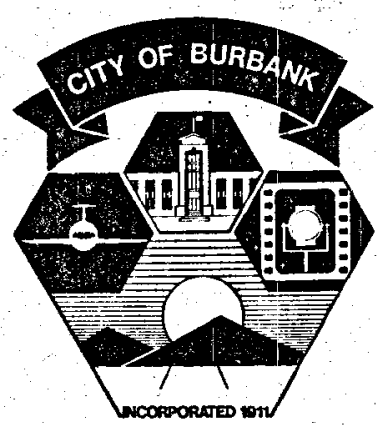

City of Burbank

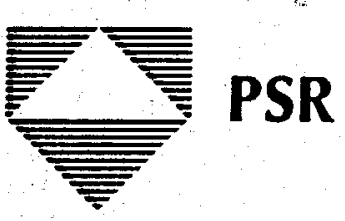




\section{DISCLAIMER}

This report was prepared as an account of work sponsored by an agency of the United States Government. Neither the United States Government nor any agency Thereof, nor any of their employees, makes any warranty, express or implied, or assumes any legal liability or responsibility for the accuracy, completeness, or usefulness of any information, apparatus, product, or process disclosed, or represents that its use would not infringe privately owned rights. Reference herein to any specific commercial product, process, or service by trade name, trademark, manufacturer, or otherwise does not necessarily constitute or imply its endorsement, recommendation, or favoring by the United States Government or any agency thereof. The views and opinions of authors expressed herein do not necessarily state or reflect those of the United States Government or any agency thereof. 


\section{DISCLAIMER}

Portions of this document may be illegible in electronic image products. Images are produced from the best available original document. 
This report presents the completed work for Task 5, High Geotherma1 Energy Utilization Hybrid Cycles, under DOE Grant Extension EG-77-G-031572. The preparation of this report was fully financed by the U.S. Department of Energy.

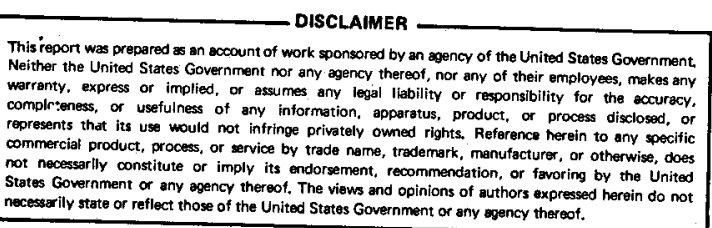

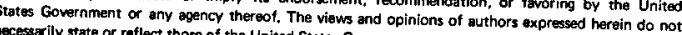
nocesserily state of reflect those of the Unitod States Government or any sgency thereoct. 


\section{ACKNOWLEDGMENTS}

This study was supported by the Department of Energy, Division of Geothermal Energy, Clifton B. McFarland, Program Manager. The work was performed by the City of Burbank's Public Service Department, with the analytical modeling being done by Pacific-Sierra Research Corporation. Sclence Advisor Acey L. Floyd was the Program Manager for the City of Burbank. The authors would also like to acknowledge the participation of George Anno and Frank Thomas of PSR, and Greg Simay of the City of Burbank.

The cost calculations are based upon a modification of the computer simulation, A Thermodynamic Process Program for Geothermal Power Plant Cycles, developed by M. A. Green and H. S. PInes of the Lawrence Berkeley Laboratory. This simulation provides the basis for the cost-optimization process in the geothermal portion of the study. 
Combining geothermal and fossil fuel energy into the so-called "hybrid" cycle is compared with a state-of-the-art double-flash geothermal power cycle using resources which vary from $429^{\circ} \mathrm{K}\left(312^{\circ} \mathrm{F}\right)$ to $588^{\circ} \mathrm{K}\left(598^{\circ} \mathrm{F}\right)$. It is demonstrated that a hybrid plant can compete thermodynamically with the combined output from both a fossil-fired and a geothermal plant operating separately. Economic comparison of the hybrid and double-flash cycles is outlined, and results are presented that indicate the performance of marginal hydrothermal resources may be improved enough to compete with existing power cycles on a cost basis.

It is also concluded that on a site-specific basis a hybrid cycle is capable of complementing double-flash cycles at large-capacity resources, and can operate in a cycling load mode at constant geothermal fluid flow rate. 


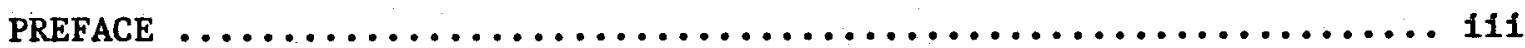

ACKNOWLEDGMENTS $\ldots \ldots \ldots \ldots \ldots \ldots \ldots \ldots \ldots \ldots \ldots \ldots \ldots \ldots \ldots \ldots \ldots \ldots$ v

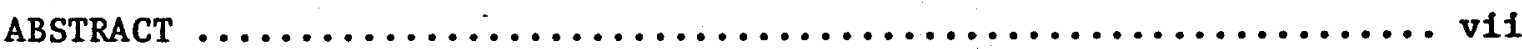

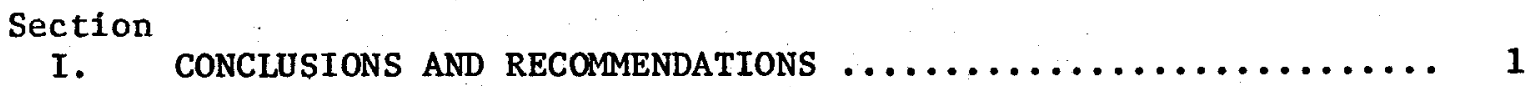

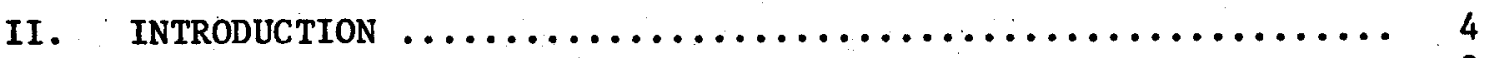

Water Chemistry Considerations .................... 9

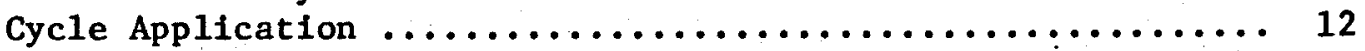

III. ANALYTICAL APPROACH $\ldots \ldots \ldots \ldots \ldots \ldots \ldots \ldots \ldots \ldots \ldots \ldots \ldots \ldots \ldots \ldots$

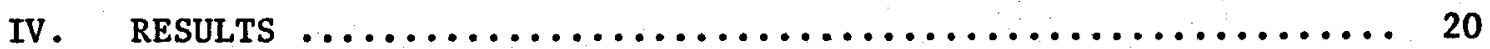

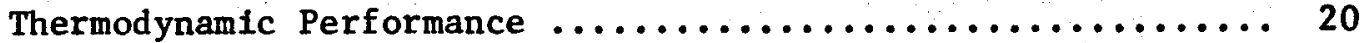

Economic Performance .............................. 24

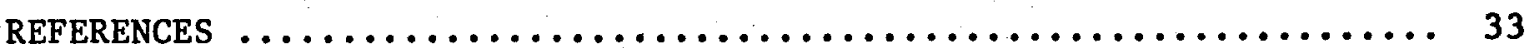

APPENDICES

A. THERMODYNAMIC PERFORMANCE CHARACTERISTICS $\ldots \ldots \ldots \ldots \ldots \ldots \ldots$ A. 1

B. OPTIMIZATION ROUTINE CHARACTERISTICS $\ldots \ldots \ldots \ldots \ldots \ldots \ldots \ldots \ldots$. $\ldots \ldots$ 


\section{CONCLUSIONS AND RECOMMENDATIONS}

Because the hybrid can exploit avallable work from the geothermal resource, fossil-fuel (coal) heat rates for the hybrid cycle are between 1 percent and 25 percent lower than the heat rate for the state-of-theart, subcritical, fossil-fired power generating station analyzed. For the conditions investigated, the hybrid cycle exhibits a clear thermodynamic advantage over coal-fired units for power levels in the range of 46 to $59 \mathrm{MW}$; moreover, the thermodynamic advantage increases with increase in geothermal resource temperature.

In addition, for geothermal fluid temperatures above $469^{\circ} \mathrm{K}\left(384^{\circ} \mathrm{F}\right)$, and under the conditions analyzed, the hybrid cycle develops more power than stand-alone coal-fired and geothermal units operating separately. Thus, from the point of view of total energy resource conservation, the hybrid cycle can be superior to independently operated, optimally designed fossil and geothermal power generating stations, depending on geothermal resource temperatures.

The capital cost of power for the hybrid plant is shown to be competitive with the capital cost of power of independently operated fossilfired and geotherma 1 units. For resource temperatures above $500^{\circ} \mathrm{K}\left(440^{\circ} \mathrm{F}\right)$, the hybrid cycle develops more total power for a lower total operating cost than the fossil unit, under the conditions of this study. At resource temperatures between $429^{\circ} \mathrm{K}$ and $469^{\circ} \mathrm{K}\left(312^{\circ} \mathrm{F}\right.$ and $384^{\circ} \mathrm{F}$, respectively), for the flow rates investigated, the hybrid cycle is capable of reducing the busbar cost of power ( $\mathrm{mills} / \mathrm{kWh}$ ) developed by the doubleflash cycle by a factor of two to three. Although judgment of overall cycle merit must be based on both thermodynamic and economic considerations, we are convinced that hybrid cycle competitiveness based on either criterion is possible on a site-specific basis.

The hybrid cycle investigated is designed to burn a relatively small quantity of coal (20 tons/hr) while maximlzing the use of avallable work from the geothermal resource. Consequently, fluid flow rate demanded by the cycle is low. The small-scale hybrid is demonstrated to operate effectively at geofluid flow rates between 50 and $64 \mathrm{~kg} / \mathrm{sec}$ (394 and 510 $\mathrm{klb} / \mathrm{hr}$ ). 
Because of cycle geometry and plant scale, the $2 \emptyset$ hybrid could have two major applications. First, the hybrid cycle provides enough power generation capacity that development of small or low-permeability geothermal resources can become economically justifiable. Consequently, otherwise unattractive, isolated circulation zones are interesting candidates for hybrid cycle application. Because of water chemistry considerations, we believe that hot-dry-rock doublet well systems capable of sustaining flow rates in the range investigated are excellent candidates for hybrid cycle development. A second application that arises due to hybrid cycle geometry is intermediate or cycling load capability. Variation of the fossil fuel feed rate allows hybrid cycle power modulation at constant geothermal resource fluid flow rate. Consequently, the hybrid cycle, utilizing a relatively small percentage of exploited geothermal fluid capacity, could provide cycling load capability at a large capacity KGRA. The balance of the hydrothermal resource could provide conventional geothermal baseload power.

Although the scope of this study is limited to the 1nvestigation of coal/geothermal hybrids, we recognize that fluidized-bed combustion; municipal waste, R-fuel, or biomass combustion; or other processes are candidates for hybrid cycle development. We recommend that combustion processes which result in low flame temperatures $\left(1000-1500^{\circ} \mathrm{K}\right)$ be considered for geothermal hybrid cycle applications. Aside from possible $\mathrm{SO}_{2}$ and/or $\mathrm{NO}_{x}$ emission abatement, the advantage of low flame temperature is that corrosion in the steam generator, in the presence of constituent TDS in the brine, can be minimized by the elimination of high-temperature gradlents in the furnace.

We recommend that a modified version of the $2 \emptyset$ hybrid cycle configuration be investigated which includes a first-point extraction-steam "feedwater" heater just upstream of the economizer, and possibly a reheater section following the high-pressure turbine stage. We belleve that such a cycle would improve the relative performance of the hybrid cycle. We also recommend that future studies that investigate alternative firing fuels or geothermal power conversion schemes should include an evaluation of hybrid cycle applicability. We expect that the thermodynamic and 
economic synergy mechanisms exhibited in this study apply to many processes that couple high-temperature energy sources with relatively lowtemperature geothermal resources. We also emphasize that quantitative figures of merit of alternative cycles will vary on a site-specific basis. 


\section{INTRODUCTION}

Since the oil embargo of 1973, increasing attention has been directed at the development of alternate energy sources to meet the future demand for power in the United States. One promising candidate for thermal and electrical power is the vast store of geothermal energy that lies virtually untapped beneath the surface of the coterminous United States, Alaska, and Hawail. Estimates of the total geothermal power that has yet to be discovered vary widely. Most experts agree, however, that such vapordominated reservoirs as the Geysers anomaly in Californta are rare. Most Known Geothermal Resource Areas (KGRAs) and, it is believed, most undiscovered geothermal resources are of the liquid-dominated variety. Liquid-dominated resources, as the name implies, are derived from hot convective circulation zones comprised of hot brine with most of the fluid in the liquid phase and a relatively small percentage of the fluid in the vapor phase.

A conventional method of utilizing 1iquid-dominated geothermal energy resources for power generation is to reduce pressure at the wellhead to "flash" the fluid isenthalpically to increase the quality or mass fraction of steam-per-pound of geofluld. Saturated vapor and liquid are then separated; the vapor phase introduced into a turbo-generator, and the liquid phase expanded isenthalpically through one or more additional stages of separation. Even under Ideal circumstances, the conversion efficlency of such a system is low because only a small cumulative fraction of the avallable work at the wellhead can be converted to work.

A thermodynamically superior and economic method for increasing the use of the geothermal resource is to incorporate a fossil-fired "topping" unit Into the cycle. Work at Brown University has shown that coal and geothermal energy can be combined to thermodynamic advantage in a single plant [1]. The Brown researchers analyzed a Rankine cycle in which geothermal energy preheated the boiler feedwater, reducing the amount of needed turbine-extraction steam. They found that 
- Thermodynamically, the hybrid plant is superior to a combination of two state-of-the-art plants, one using only fossil energy, and the other using only geothermal energy;

- Geothermal energy is used more efficiently in the preheat hybrid cycle than in any presently conceived al1-geothermal cycle.

Although the thermodynamic advantage of the hybrid plant has been established, the economics of cycle operation is still an open question, depending largely on site-specific considerations, since a hybrid plant would have to be located near the geothermal resource. Previous work at Pacific-Sierra Research Corporation [2,3] has attempted to answer the question of economic feasibility for the geothermal feedwater preheat hybrid cycle on a site-specific basis, for both subcritical and supercritical binary cycle operation.

Our objective in this analysis is to investigate the performance of a fossil fuel/geothermal hybrid cycle that maximizes the use of a geothermal resource, while burning relatively small quantities of fossil fuel. In addition, by maximizing the utilization of the geothermal resource, we hope to demonstrate a method by which enough power can be developed using resources of marginal temperature and/or capacity so that development of "poor" resources can become economically justifiable.

This analysis is intended to be a preliminary investigation of technical and economic feasibility of generic, high-geothermal-utilization hybrid systems. We have limited our study to one configuration of a hybrid "topping" cycle that represents the best cycle we were able to develop in the limited time avallable. We believe a modification to this cycle that incorporates a high-pressure extraction-steam feedwater heater, and possibly a reheater, would improve the results presented here for the hybrid cycle, espectally for the low-resource-temperature cases.

As stated above, previous investigations indicate that a thermodynamic advantage can be realized by incorporating geothermal condensatel feedwater heating into a "bottoming," binary-configuration, modifiedRankine hybrid cycle. To investigate the performance characteristics of a topping cycle, a review of alternative approaches is helpful. We 
assume for the present discussion that possible topping cycles are applied to resources that exhibit saturated water characteristics at the wellhead. The analysis could readily be extended to resources that exhibit mixedphase flow if the discussion is applied to the saturated liquid developed as a result of the first stage of separation.

Referring to Fig. 1, geothermal fluid could be assumed to exit from the well as saturated water at point one. A conventional technique for utilizing liquid-dominated geothermal resources is to expand the fluid isenthalpically to some point in the dome. This expansion, which results in temperature drop and increase in entropy from the wellhead state, represents a decrease in avallable work and a drop in the maximum efficiency that can be realized by any thermal power system. However, by expanding the fluid, quality is increased, thereby permitting the accomplishment of $\mathrm{p}-\mathrm{v}$ work in an expansion turbine. In addition, the quality increase with increased expansion permits more steam to flow through the turbine until maximum quality is achieved.

Unfortunately, maximum quality occurs at the sink temperature, where available work is zero. The expansion tradeoff in flashing-type systems, then, is between quality and avallability, or in practical systems, between quality and useful work. Since specific power is related to the product of quality and enthalpy difference, an optimum point can be found for isenthalpic expansion. In pure geothermal systems with an initial fluid quality of zero, it has been found that for two stages of flash, each stage should sustain an expansion such that temperature drop across each stage is approximately

$$
\Delta T=\frac{T_{g}-T_{s}}{3}
$$

where $T_{g}$ denotes wellhead temperature and $T_{S}$ denotes sink temperature. The available work at the wellhead can be described as

$$
w_{g}=\left(h_{g}-h_{s}\right)-T_{s}\left(s_{g}-s_{s}\right)
$$

for isenthalpic expansion, the decrease in available work through each stage is 


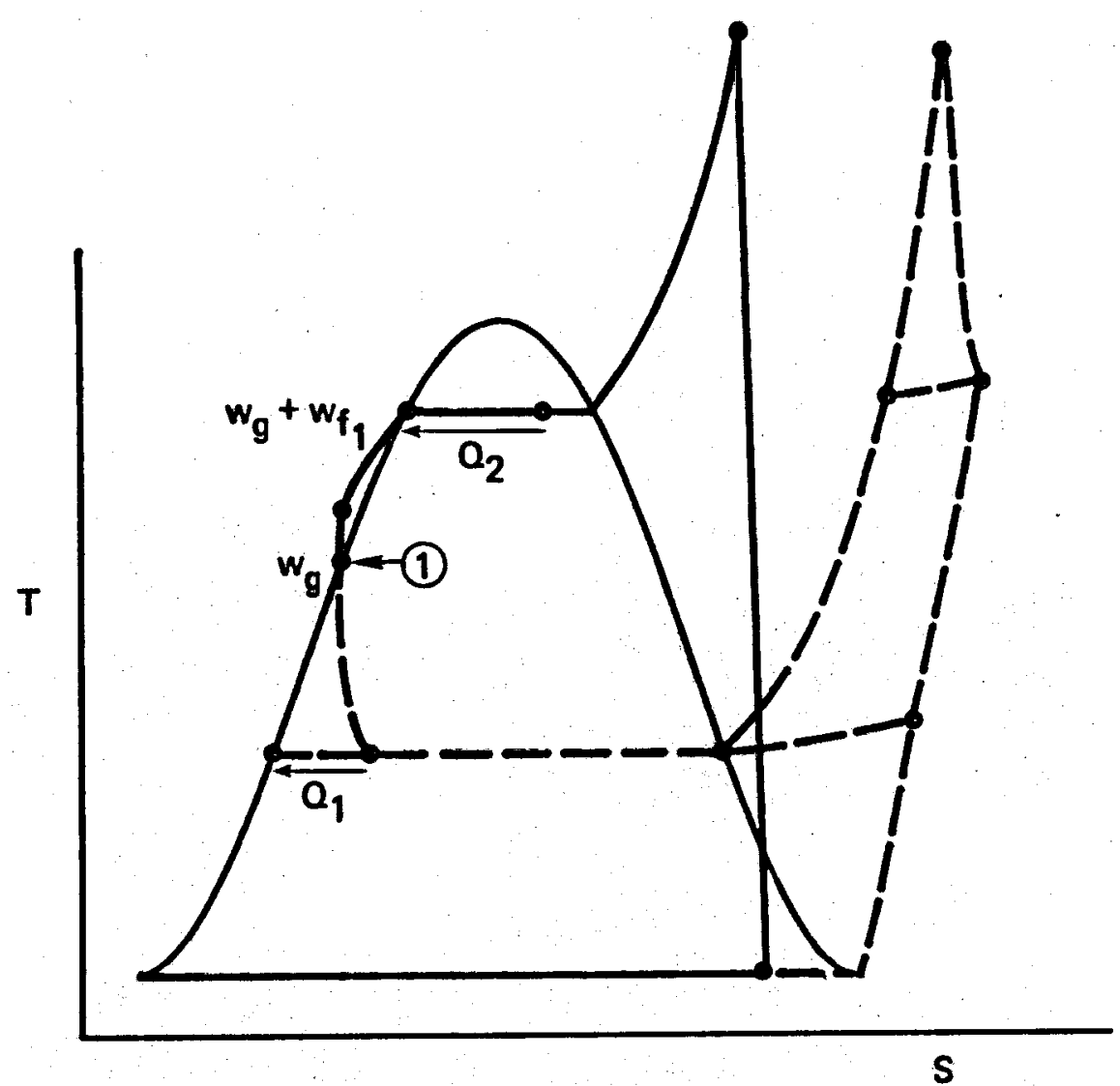

Heat rejected prior to superheat:

Pure superheat hybrid

$Q_{1}=(1-\beta) a w_{g}$ where $\alpha=$ fractional decrease in available work $\beta=$ quality

Two-phase hybrid

$Q_{2}=(1-\gamma)\left(w_{g}+w_{f}\right)$

where $\boldsymbol{\gamma}=$ quality

$w_{g}=$ available work of geofluid

$w_{f_{1}}=$ available work due to non-supertieat fossil

Fig. 1--Temperature-entropy diagram for pure superheat (dotted), and two-phase (solid) fossil-topping hybrid cycles. 


$$
\Delta w=-T_{0}\left(s_{1}-s_{i+1}\right)
$$

For a unit mass flow rate from the well, the mass flow rate through successive expansion and separation stages results in progressively lower incremental increases in flow rate through the turbine stages. Thus, multiple stages of expansion suffer a dual penalty: decrease in ava11able work and small incremental increases in mass fractional flow rate through the turbine stages. The current practical 11mit of expansion stages is generally considered to be two, with approximately 70 percent of initial saturated flow never passing through a turbine. These characteristics of flashing-type thermal conversion systems have a thermodynamic effect on performance of fossil topping hybrid cycles that are retrofitted to flashing systems.

If fossil fuel is to be used for pure superheating in a non-binarytype hybrid cycle, the conversion of the hydrothermal resource to saturated vapor must be accomplished by a refrigeration process with attendant losses as described above to produce saturated vapor at relatively low pressure (see Fig. 1). The losses incurred due to decrease in temperature must be recovered by either the combustion of fossil fuel in a low second-law efficiency superheater or the incorporation of a gas regenerator into the cycle to provide primary superheat. Finishing superheat provided by the fossil fuel can then increase the overall cycle-available work to limits far above the initial $\mathrm{w}_{\mathrm{g}}$ at very favorable combustion efficiencies. Even with initial losses in available work, and with a fraction of the initial geofluid flow rate, this type of superheat hybrid cycle has demonstrated a thermodynamic advantage over individual fossil and geothermal power plants operating alone [4].

However, we have developed a second type of fosstl topping, nonbinary hybrid cycle (see Fig. 1). In this cycle, saturated water is pressurized to a subcooled state, introduced directly into an economizer, and, if the fluid were pure water, introduced directly into the steam generator. Assuming subcritical operation, crossing the dome at high pressure minimizes the production of entropy of formation and allows maximum state-of-the-art turbine inlet temperatures and pressures to be attained at the superheater outlet, with minimum entropy production in 
the fossil energy conversion process. Note that because of the fossil fuel energy contribution in this fashion, avallable work from the georesource, $w_{g}$, is not degraded and can therefore be converted to electrical power at Carnot efficiency times a factor to account for non-isentropic effects of the expansion turbine $\left(n_{t} \approx 0.9\right)$ and the generator. Although turbine inlet conditions would be similar to those achieved in state-ofthe-art fossil-fired generating stations, a major reduction in heat rate coula be obtained because large quantities of regeneration extraction steam would not be required. Thermodynamically, this cycle represents a performance limit which could be approached by feedwater-preheat hybrid cycles as heater pinch points approach zero.

Although a simple topping cycle as described represents a thermodynamic optimum, such a configuration would operate properly only if the hydrothermal fluid were extremely low in dissolved sollds and exhibited a moderate $\mathrm{pH}$. Because hydrothermal fluid is likely to be highly loaded with dissolved solids, a modification to the cycle must be made to protect the tubes in the steam generator and superheater. We emphasize that cycle modification is introduced for reasons of water chemistry, and not thermodynamic performance.

\section{WATER CHEMISTRY CONSIDERATIONS}

Boiler tube sensitivity to the water/steam environment is complex and can be attributed to different mechanisms. On the so-called water side of a steam generator, corrosion can occur because of either low or high pH. A relatively dense deposition of acid salts locally precipitated from the boiler water can result in the localized production of hydrogen in sufficient concentration to allow a certain amount of the hydrogen to diffuse through the $\mathrm{Fe}_{3} \mathrm{O}_{4}$ (magnetite) layer on the steel tube inner wal1. Hydrogen then combines with carbon in the steel to produce methane gas, which exerts pressure at the grain boundaries in the metal. Brittle fracture can proceed along boundaries unt1l the tube is weakened to the point that tensile failure occurs. This type of fallure is relatively common in boiler tubes if the boiler water $\mathrm{pH}$ is allowed to drop to much less than about 4 (see Fig. 2), even when PPM loading is light. This fracture mode is very difficult to detect prior to tube fallure. Conversely, excessively alkaline solutions tend to cause a type of corrosion process 


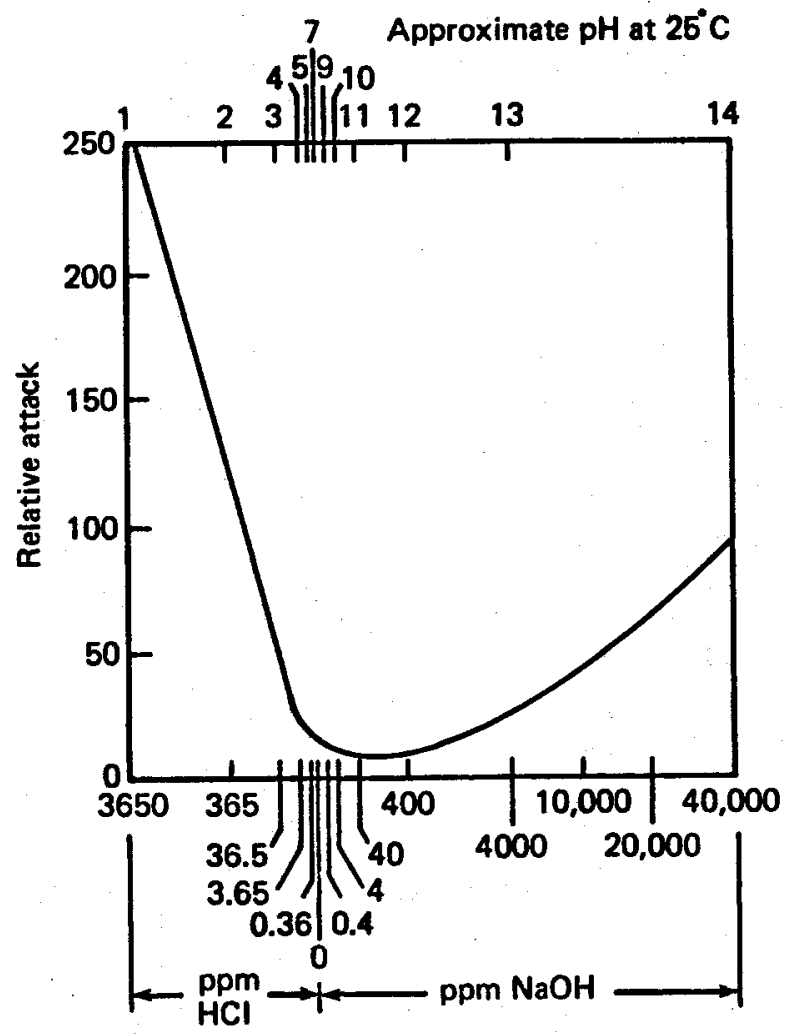

Fig. 2--Acidic or alkaline attack on boiler tubes (from Ref. 5)

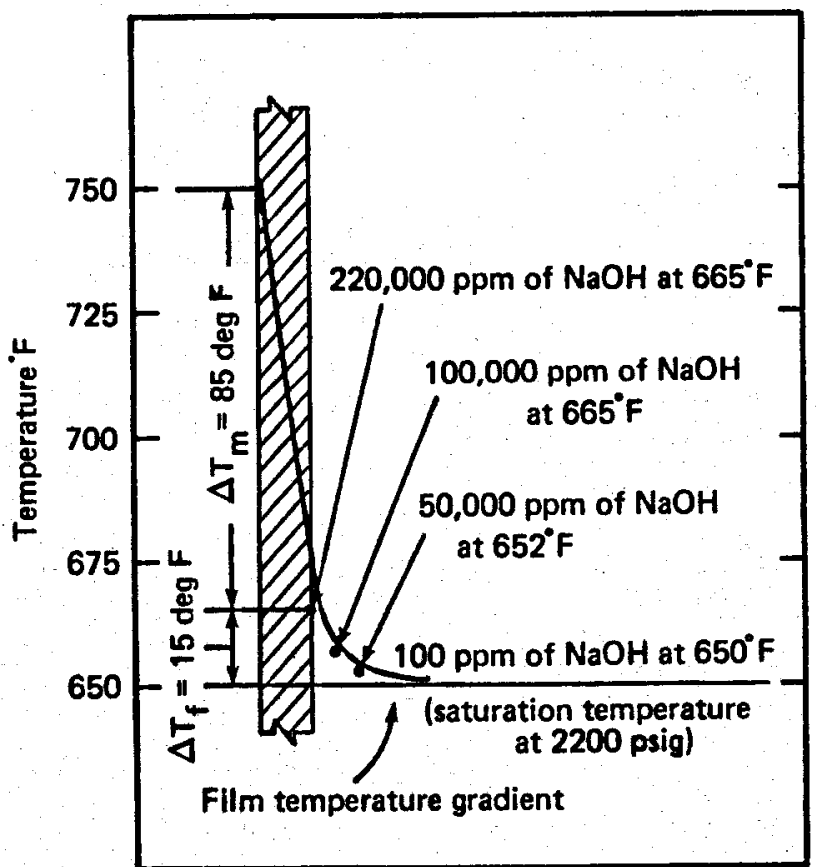

Fig. 3--Soluble solids concentration in surface film during boiling (from Ref. 6) 
referred to as "caustic gouging." This type of gouging corrosion causes ductile failures and, in the presence of hydroxide salts, generally occurs when the fluid $\mathrm{pH}$ is above about 12. Indications are that maintenance of brine $\mathrm{pH}$ in the range of 4 to 12 must be ensured to prevent water-side corrosion in the tubes.

As nucleate bolling in forced convection proceeds to film boiling in the steam generator, a thin layer of vapor can form at the tube wa11, causing the convective heat-transfer coefficient near the wall to drop. The resultant temperature gradient can cause a substantial increase in concentration of dissolved sollds within the film (see Fig. 3). In the presence of porous internal deposits on the wall, very high local concentrations of solids can occur in areas of high heat absorption.

Increasing steam quality within the boiler tends to cause a macroscopic increase in concentration of total dissolved solids within the liquid phase until chemical saturation occurs. Further increases in steam quality would result in precipitation of solids in the form of scale on the tube wall. Evidence exists that even light concentrations of calcium sulfate or calcium carbonate can result in extensive scaling.

These mechanisms suggest that certain precautions be taken if geothermal brine is to be considered for direct introduction into a steam generator. To protect the water side of the boiler, $\mathrm{pH}$ control of resource fluid to values between 4 and 12 should be maintained. $\mathrm{H}_{2} \mathrm{~S}$ or $\mathrm{CO}_{2}$ removal, or chemical addition to the brine, may be required on a sitespecific basis. We belleve that many hydrothermal resources exhibit $\mathrm{pH}$ characteristics well within the range required and would require no treatment for $\mathrm{pH}$ control. To protect the steam side of the boiler, several schemes might be practical. Since even light concentrations of certain salts such as calcium sulfate can cause extensive scaling, careful analysis should be made of hydrothermal resource fluid on a sitespecific basis before the hybrid cycle design configuration is finalized. We consider the inability of the tubes to sustain even 1ight concentrations of certain constituent salts without scaling to be the most serfous drawback to direct-heat-addition topping hybrid cycles.

For hydrothermal resources that exhibit moderate chemistry, two issues become Important: first, what quality can be attained in the 
steam generator; and second, how temperature gradients can be controlled to reduce the likelihood of localized high concentration of corrosive agents. The first issue is directly related to solubility of the constituents as a function of temperature. As fluid changes phase, the increase in solubility usually achieved by increase in temperature through the water side of the boiler is traded against the decreasing mass fraction of fluid that remains in the liquid phase. We believe that the degree of "dome crossing" that can be sustained must be determined on a site-specific basis. When an optimum steam quality is obtained, no further heat addition should occur. The fluid should pass from the boiler tubes into an exit header and be removed from the boiler. The fluid could then be introduced into a separator, where chemically and thermodynamically saturated liquid would be removed. Thermodynamically saturated high-pressure vapor could then be introduced into the superheater and subsequently discharged through the turbines. This flow arrangement suggests that a drum-type unit would be inappropriate for this hybrid cycle and that a modified subcritical once-through steam generator could be considered.

The second issue, espectally significant with coal-fired units which exhibit high flame temperature, suggests that the boller configuration be designed to avoid local hot spots. Although this study does not explore the possibilities that could be developed with respect to boller design, we do recognize that current efforts to develop fossil fuel-fired brackishwater superheaters, as well as the developing technology of fluidized-bed coa1-fired furnaces with relatively low flame temperatures, could provide interesting candidates for further study in a topping hybrid cycle.

\section{CYCLE APPLICATION}

We Imagine that hot, chemically saturated brine, such as the type found at Niland in the Imperial Valley, would be a poor candidate for the hybrid cycle described because the quality of steam developed in the boiler would be low, thereby resulting in the use of a small fraction of the available work derived from both the geothermal resource and the combustion of fossil fuel: The low quality of the steam would also result in a small mass flow rate through the turbines. Conversely, the fluid 
extracted from a hot dry-rock resource might be a good candidate because relatively high quality could be attained in the boiler, depending on the degree of silica concentration that could be sustained at boller temperature.

Figure 1 illustrates the thermodynamic tradeoffs that exist between a pure superheat hybrid cycle and a two-phase topping hybrid cycle. The superheat hybrid cycle appears to be a reasonable candidate for application of hydrothermal resources that exhibit relatively large fluid flow rates and moderately high wellhead pressures. The superheat cycle is somewhat insensitive to initial brine chemistry because separation tends to decrease the likelihood of high-solids carryover into the superheater tubes. Since this cycle has been analyzed extensively [4], it is not investigated further in this study. 


\section{ANALYTICAL APPROACH}

The two-phase fossil topping hybrid cycle, which we call the 20 configuration, that was analyzed in this study is shown in Fig. 4. Our developmental approach was to approximate a simple Rankine cycle as closely as possible. A phase separator was added to eliminate the "fatal flaw" associated with direct bofling and superheating of brine. We attempted to develop a cycle which would maximize the use of the geothermal resource in terms of both available work and power. Inttially, we hoped that we could develop a cycle capable of utilizing between 60 . and 80 percent of the hydrothermal fluid extracted with no second-law efficiency degradation of the fossil-fuel combustion process. Consequently, the need for excessive resource flow rates requiring multiple wells and a large hydrothermal resource was eliminated. Since we were presented with an opportunity to investigate a cycle suitable for sma11-sized hybrids, we arbitrarily restricted our scope of fossil-fired heaters to include only coal-fired stoker-type furnaces. These units represent a very simple, we11-known, and economical method for supplying steam at flow rates up to about $300,000 \mathrm{lb} / \mathrm{hr}$. We reasoned that a satisfactory cycle could then be expected to operate with a resource fluid flow rate of about 500,000 $\mathrm{lb} / \mathrm{hr}$, the capacity of one moderately productive well. This cycle is of practical interest because it is applicable to many small hydrothermal resources, or part of a larger KGRA.

We decided that two reasonable criteria for judgment of the $2 \emptyset$ hybrid cycle performance would be: 1) net electrical power developed by the hybrid compared to the sum of the power developed by independently operating fossil and geothermal stations, each consuming the amount of thermal power input to the hybrid; and 2) cost of power from the hybrid compared to the cost of power of the two stand-alone plants.

The analytical approach taken was to develop three schematic thermal power cycles: an all-fossil cycle, an all-geothermal cycle, and the 20configuration hybrid. The hybrid cycle was forced to operate using the same fossil fuel consumption rate as the al1-fossil cycle. Hydrothermal fluid flow rate demanded by the hybrid cycle was then used as the thermal power input to a double-flash geothermal cycle for parametric 


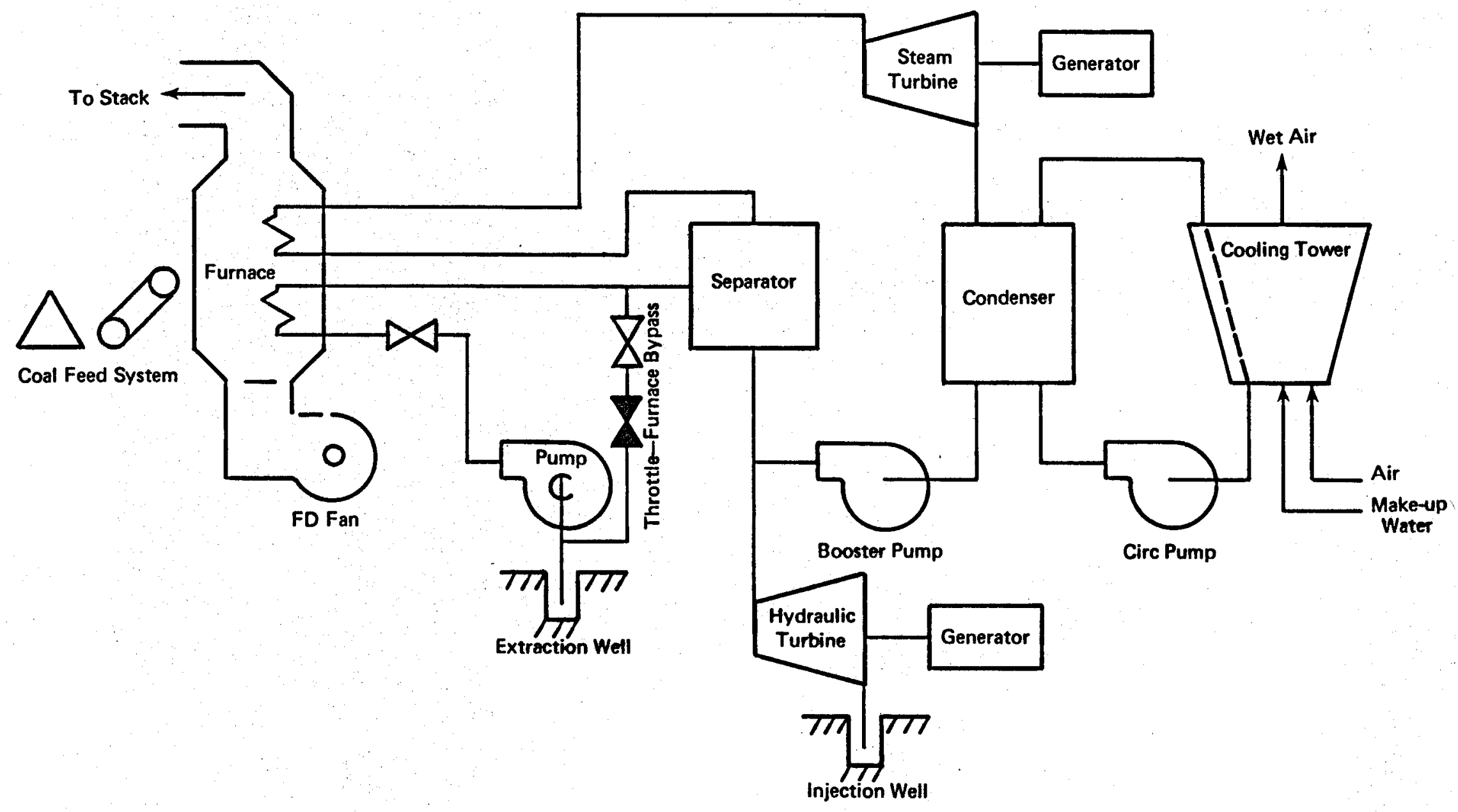

Fig. 4--2ø hybrid cycle configuration 
values of geothermal resource temperature. Furnace configuration was chosen to be a fixed-design stoker unit for the study, with a fuel consumption rate of $40,000 \mathrm{lb} / \mathrm{hr}$. Although hybrid performance could have been investigated using oil, R-fuel, municipal waste, or other combustible fuels, we limited our investigation to the use of Emery-Wasatch coal, with a dry heating value of $11,557 \mathrm{Btu} / \mathrm{lb}$. The furnace, along with the other components of the cycle, was then incorporated into a computer model based on the program GEOTHMF, with cost algorithm modifications to describe the furnace, air preheater, fans, and coal-feed system. In addition, we wrote a separator algorithm and a hydraulic turbine costestimating algorithm.

Addition of these changes to modifications developed in a previous study of fossil/geothermal hybrid cycles [2] provided us with an analytical tool for investigating the performance of a fossil-fired unit, a double-flash geothermal unit, and the $2 \emptyset$-configuration hybrid unit. The fossil-fired state-of-the-art plant was modeled and optimized first (see Fig. 5). Pinch points on the superheater and reheater, extraction steam temperatures, pressures, and $f$ low rates were designated optimizable parameters. Numerical optimization using the computer program and maximum electrical power as the objective function yielded a cycle geometry with state points and flow rates very simflar to state-of-the-art fossil-fired units. This numerical optimization procedure accomplished two objectives. First, we gained confidence in our cost-estimating algorithm and in the ability of the computer to design a cycle with realistic heat rate and flow characteristics. Second, we were able to develop a relative base for fossil fuel utilization against which to compare the $2 \emptyset$ hybrid cycle, both in terms of thermodynamic and economic performance.

Using the "identical" furnace in our 20 hybrid cycle (see Fig. 4 ), we were able to optimize hybrid performance for parametric values of wellhead pressure, with wellhead quality maintained at zero. Optimization of the $2 \emptyset$ cycle was based on two separate computer runs for each parametric wellhead condition. The first run optimized cycle performance based on busbar cost of power as the objective function. The second run optimized cycle performance with maximum power output as the objective function. Since maximum power is more sensitive to optimizable 


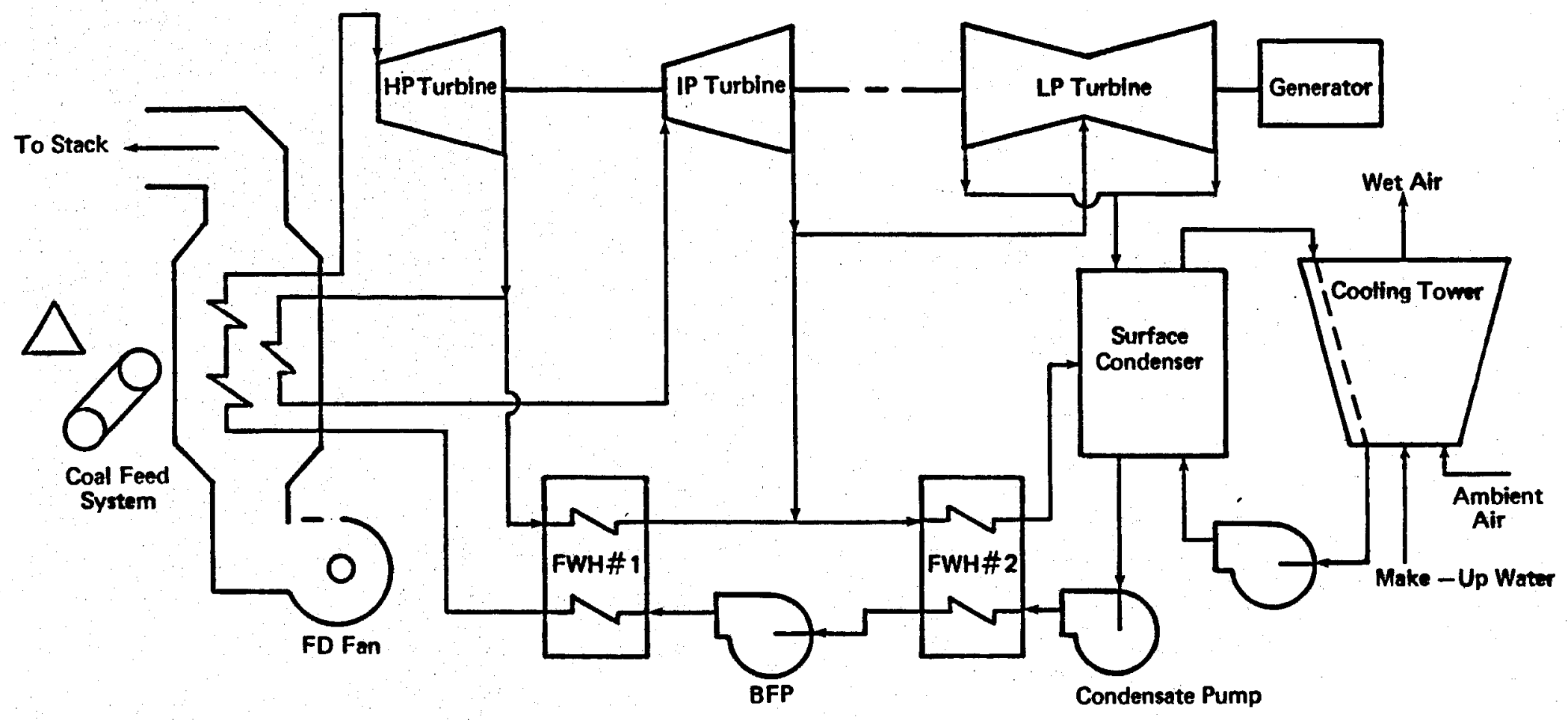

Fig. 5--Fossil-fired state-of-the-art power cycle 
parameter variation, the results presented in this report are based on the maximum power objective function runs. For parametric values of wellhead pressure (and therefore temperature), optimum cycle performance demands varying flow rates from the hydrothermal resource. Consequently, unique values of wellhead temperature, pressure, and flow rate were developed for each case. Since these values represent the thermal power avallable to the hybrid from the geothermal resource, these characteristic values were input to the optimization routine for the double-flash all-geothermal cycle shown in Fig. 6 .

Double-flash cycle operation at relatively low temperatures, pressures, and flow rates in the range studied here result in low power levels and therefore small turbines. Since small-turbine operation is normally not cost optimized with large, low-pressure surface condensers, we chose to increase the last-stage turbine backpressure slightly for all the cycles. We believe that the cost advantage of the larger fossil and hybrid units justifies the use of lower-pressure condensers but would introduce a thermodynamic bias against the double-flash cycles, which is unfair. We recognize that site-specific optimization of alternative cycles should allow thermodynamic sink limits to vary.

In addition, we should point out that the cost-estimating subroutines for turbogenerators is developed basically from the GE turbine schedule, using 3600-RPM machines. However, in our algorithm the double-flash cycles, or any cycle which demands a turbogenerator of less than $10 \mathrm{MW}$, is priced on the basis of a 5000-RPM machine, typically with a six-pole generator. This characteristic "break" tends to reduce the size and cost of turbines for the double-flash cycles analyzed as part of this study. 


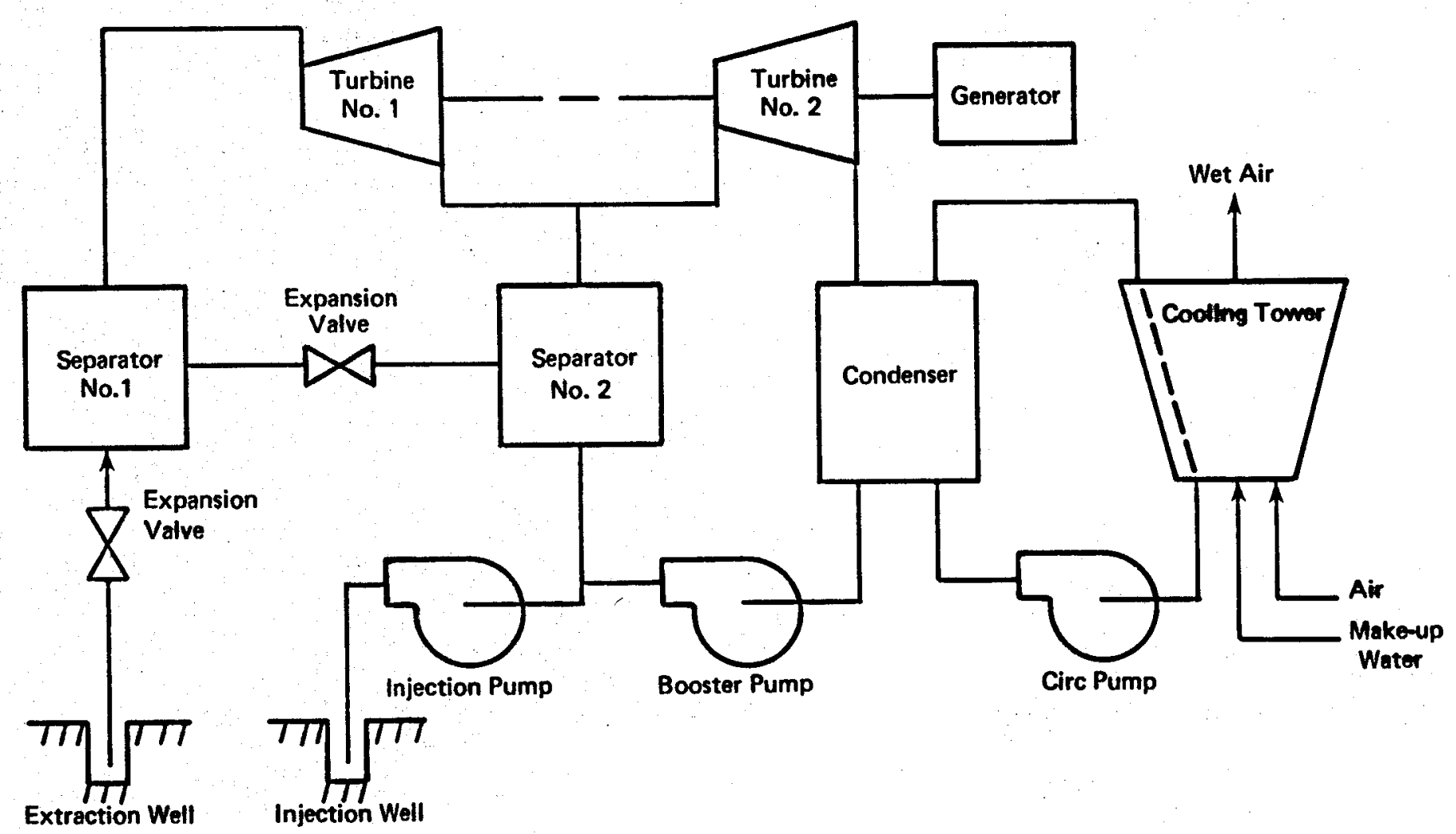

F1g. 6--Double-flash geothermal cycle 


\section{RESULTS}

\section{THERMODYNAMIC PERFORMANCE}

To compare cycle performance among the all-fossil, double-flash, and hybrid cycles, cases were run that use identical resource conditions, flow rates, and operating environments. Table 1 summarizes the thermodynamic operating characteristics, power outputs, and thermodynamic figures of merit for the three cycles.

Referring to Fig. 7, one can see that the two figures of merit developed in Table 1 indicate the relative performance of the hybrid cycle on the basis of power. Figure of merit $F_{1}$ is defined to be the ratio of the power developed by the hybrid power plant to the power developed by a fossil plant and a geothermal plant operating independently. $F_{1}$ indicates that for the cycles modeled under the conditions assumed in this study, optimization of power developed can be obtained using the hybrid cycle for hydrothermal resource temperatures above about $470^{\circ} \mathrm{K}\left(387^{\circ} \mathrm{F}\right)$. Conversely, on the basis of total power produced, independently operated fossil and geothermal power plants develop more power for resources with temperatures below $470^{\circ} \mathrm{K}$. $F_{1}$, then, is a purely thermodynamic figure of merit.

Figure of merit $F_{2}$ is an expression for the relative power developed by the hybrid cycle compared to the power developed by the combustion of an equal amount of coal in a stand-alone fossil-fired power generating station. $F_{2}$ represents the merit of the hybrid cycle in terms of decrease in fossil fuel heat rate when development of a pure geothermal plant cannot be justified on economic grounds, and becomes an important index of total resource utilization if economical operation of the hybrid cycle can be demonstrated.

Figure 8 shows the reduction in fossil fuel heat rate which can be attained by utilizing the hybrid cycle. The reduction in heat rate is a direct indication of the decrease in BTUs required from the combustion of fossil fuel for each kilowatt hour produced, and is thus an important indicator of fossil fuel energy conservation which can be attained by use of geothermal energy in the $2 \emptyset$ hybrid cycle. 
CYCLE THERMODYNAMIC CHARACTERISTICS

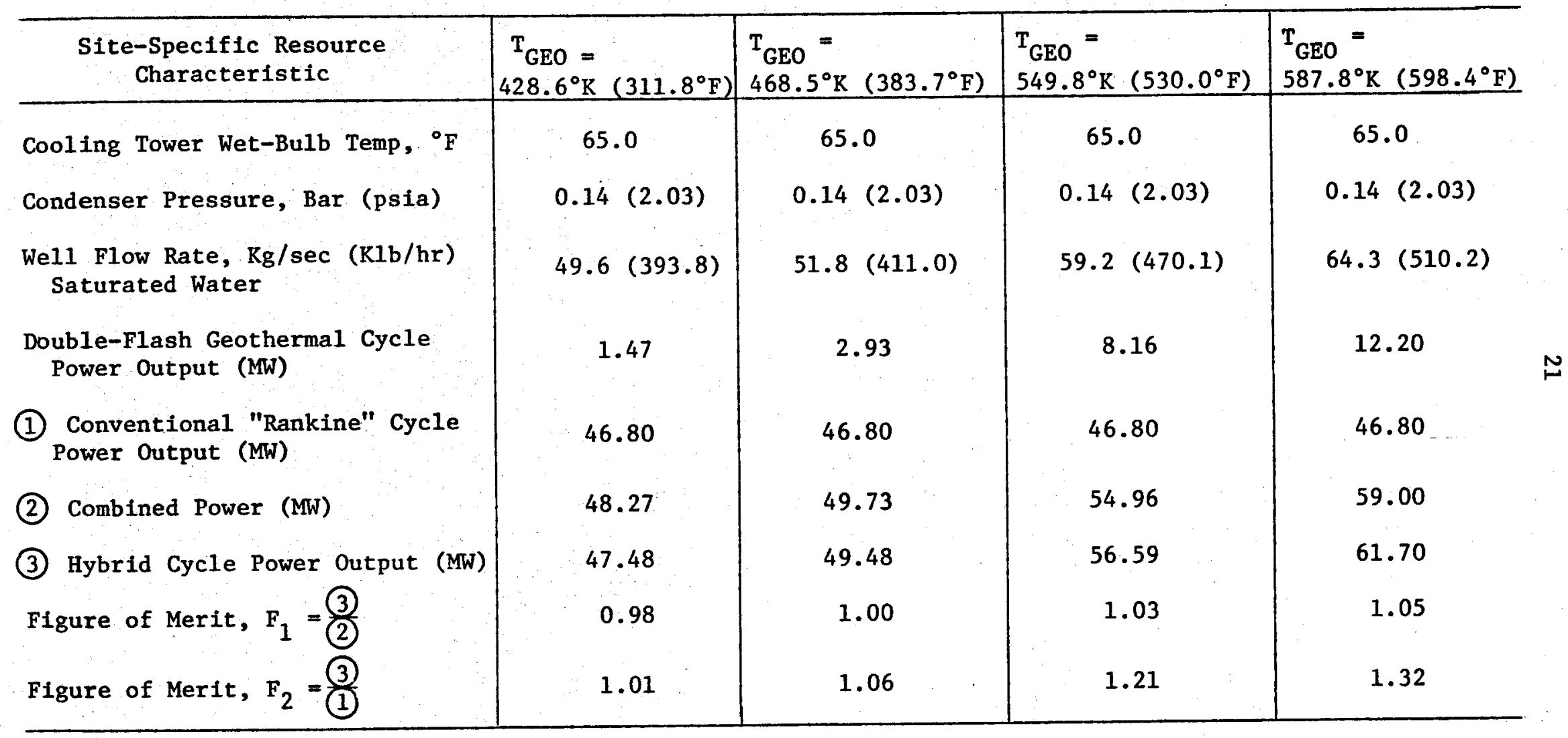




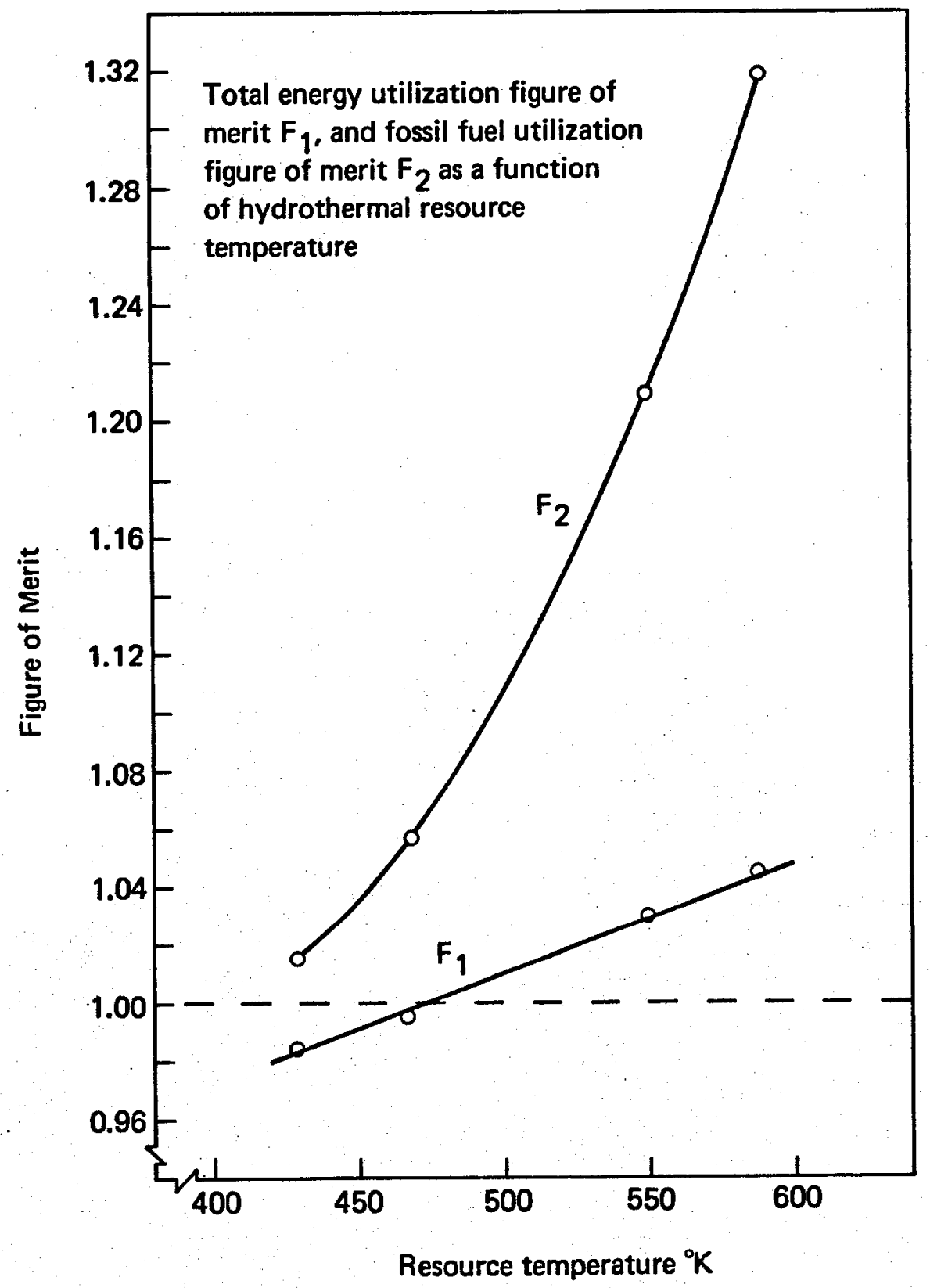

Fig. 7--Thermodynamic figures of merit 


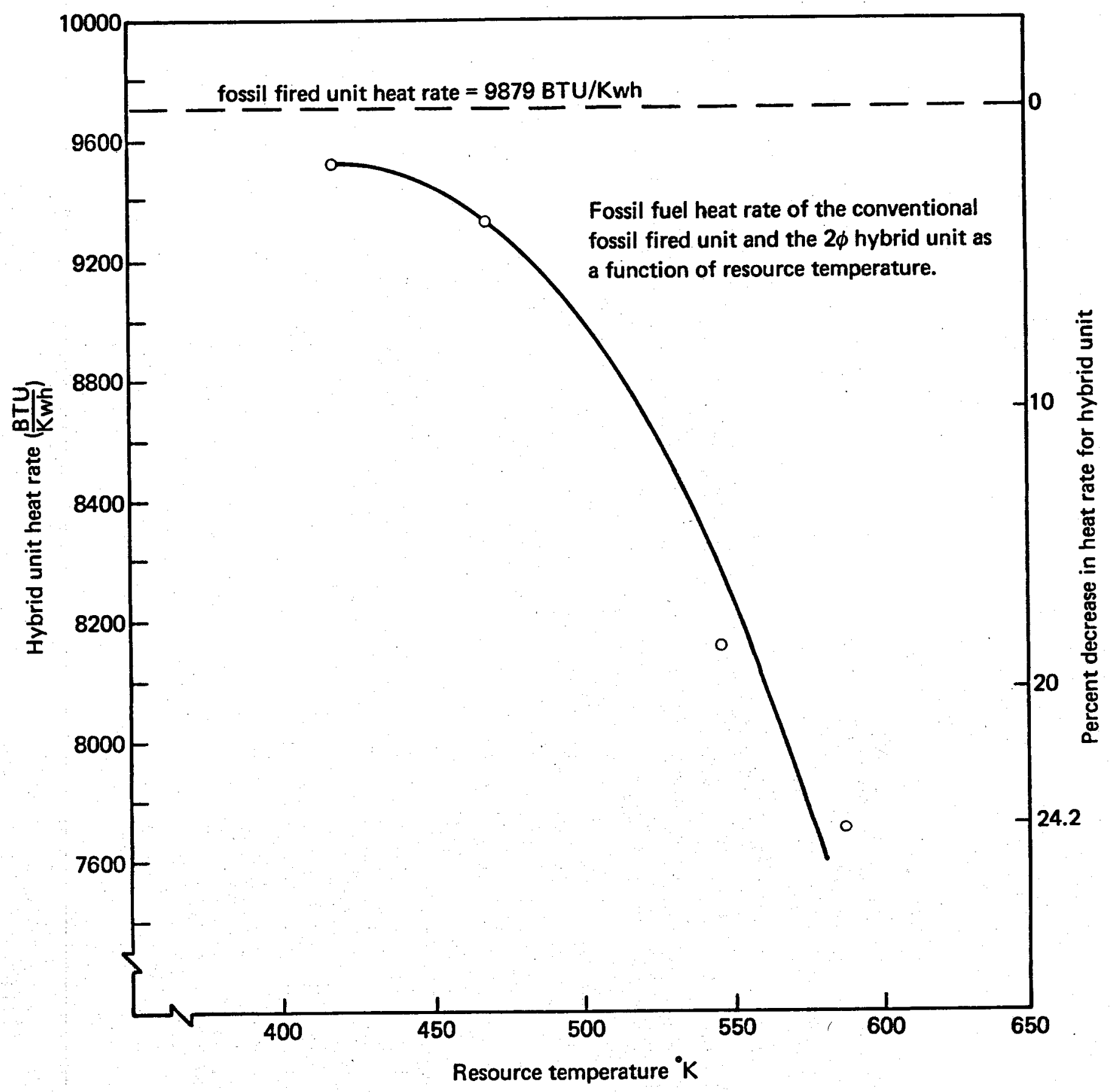

Fig. 8--The effect of geothermal resource temperature on fossil fuel combustion heat rate 


\section{ECONOMIC PERFORMANCE}

Relative competitiveness of the $2 \emptyset$ hybrid cycle can be measured quantitatively in terms of capital cost and total amortized capital and operating costs. In addition, a qualitative determination can be made of risk of expected resource life and site applicability of the hybrid cycle.

Table 2 summarizes capital costs, including direct materials; capital equipment, capital subsystems, and direct and indirect labor for the geothermal, fossil, and hybrid cycles.

Time-dependent, or varlable, cost factors are summarized in Table 3 , along with'the fixed-rate parameters that affect the net present value of the facilities. Table 4 presents the levelized cost of each power station in mills/kWh.

Although actual costs must be estimated on a site-specific basis, direct comparison of the capital cost of power and operating cost of power at the busbar demonstrates the relative economic merit of the three cycles under the operating conditions analyzed. Operation and maintenance of the geothermal plant is escalated at an annual rate of 17 percent, whereas the rate of escalation for the hybrid plant is only 10 percent, and for the fossil plant, only 6 percent (see Table 3). The difference in rates is due to the relatively large percentage of capital equipment in the double-flash cycle that is dedicated to brine handing. The actual annual cost of plant operation and maintenance is greater for the hybrid system than for the double-flash system.

The variation in rates represents variation in our estimates of expected revenue streams which must be expended for the three cycles. Note that the net present value discount rate does not vary among the cycles.

Table 2 Indicates that the capital cost of power for the fossi1fired unit is approached by the hybrid cycle, even at low resource temperature. The double-flash cycle, however, exhibits a very high capital cost of power at $429^{\circ} \mathrm{K}$. Even at resource temperatures as high as $588^{\circ} \mathrm{K}$, the geothermal capital cost of power is almost twice that of the fossil-fired unit. The high capital cost of power for the double-flash cycles is due to the fact that relatively low levels of power are developed at the 
Table 2

CAPITAI, COST OF POWER

\begin{tabular}{|c|c|c|c|c|c|c|c|c|c|}
\hline \multirow[b]{2}{*}{ Component } & \multirow{2}{*}{$\begin{array}{c}1976 \text { Cost } \\
\text { (MM\$) } \\
\text { Coal-F1red } \\
\text { RankIne Cycle } \\
\text { 1-Stage Reheat } \\
\text { 2-Stage Regen. }\end{array}$} & \multicolumn{2}{|c|}{$\mathrm{T}_{\mathrm{GEO}}=428.6^{\circ} \mathrm{K}\left(311.8^{\circ} \mathrm{F}\right)$} & \multicolumn{2}{|c|}{$T_{G E O}=468.5^{\circ} \mathrm{K}\left(383.7^{\circ} \mathrm{F}\right)$} & \multicolumn{2}{|c|}{$T_{\text {GEO }}=549.8^{\circ} \mathrm{K}\left(530.0^{\circ} \mathrm{F}\right)$} & \multicolumn{2}{|c|}{$\mathrm{T}_{\text {GEO }}=587.8^{\circ} \mathrm{K}\left(598.4^{\circ} \mathrm{F}\right)$} \\
\hline & & $\begin{array}{c}1976 \text { Cost } \\
\text { (MM\$) } \\
\text { Hybrid Cycle }\end{array}$ & $\begin{array}{c}1976 \text { Cost } \\
\text { (MM\$) } \\
\text { Double-Flash } \\
\text { Cycle }\end{array}$ & $\begin{array}{c}1976 \text { Cost } \\
\text { (MM\$) } \\
\text { Hybrid Cycle }\end{array}$ & $\begin{array}{c}1976 \text { Cost } \\
\text { (MM\$) } \\
\text { Double-Flash } \\
\text { Cycle }\end{array}$ & $\begin{array}{l}1976 \text { Cost } \\
\text { (MM\$) } \\
\text { Hybrid Cycle }\end{array}$ & $\begin{array}{c}1976 \text { Cost } \\
\text { (MM\$) } \\
\text { Double-Flash } \\
\text { Cycle }\end{array}$ & $\begin{array}{l}1976 \text { Cost } \\
\text { (MM\$) } \\
\text { Hybrid Cycle }\end{array}$ & $\begin{array}{c}1976 \text { Cost } \\
\text { (MM\$) } \\
\text { Double-Flash } \\
\text { Cycle }\end{array}$ \\
\hline Land & 0.225 & 0.226 & 0.040 & 0.231 & 0.056 & 0.247 & 0.094 & 0.258 & 0.115 \\
\hline Structure & 7.116 & 7.194 & 0.532 & 7.421 & 0.891 & 8.206 & 1.920 & 8.756 & 2.596 \\
\hline $\begin{array}{l}\text { Station Electrical \& } \\
\text { Accessory Equip. }\end{array}$ & 1.260 & 1.276 & 0.056 & 1.325 & 0.104 & 1.495 & 0.262 & 1.616 & 0.376 \\
\hline Indus. Waste Equip. & 0.500 & 0.500 & 0.000 & 0.500 & 0.000 & 0.500 & 0.000 & 0.500 & 0.000 \\
\hline Miscellaneous Equip. & 1.507 & 1.527 & 0.067 & 1.585 & 0.125 & 1.788 & 0.313 & 1.933 & 0.449 \\
\hline Bofler & 4.000 & 4.000 & N/A & 4.000 & $\mathrm{~N} / \mathrm{A}$ & 4.000 & N/A & 4.000 & N/A \\
\hline Condenser & 0.092 & 1.539 & 0.022 & 1.604 & 0.035 & 1.835 & 0.062 & 1.995 & 0.087 \\
\hline Turbine Generator & 5.376 & 4.602 & 0.135 & 4.533 & 0.411 & 4.900 & 1.627 & 5.480 & 2.266 \\
\hline Separator $(s)$ & $\mathrm{N} / \mathrm{A}$ & 0.037 & 0.340 & 0.037 & 0.059 & 0.045 & 0.124 & 0.061 & 0.182 \\
\hline Pump No. 1 & 0.045 & 0.045 & 0.000 & 0.046 & 0.000 & 0.046 & 0.000 & 0.034 & 0.001 \\
\hline Pump No, 2 & 0.005 & 0.028 & 0.003 & 0.029 & 0.006 & 0.032 & 0.023 & 0.035 & 0.041 \\
\hline Pump No. 3 & 0.016 & 0.041 & 0.004 & 0.042 & 0.006 & 0.048 & 0.009 & 0.052 & 0.013 \\
\hline Hydraulic Turbine & $\mathrm{N} / \mathrm{A}$ & 0.090 & N/A & 0.087 & N/A & 0.066 & N/A & 0.037 & N/A \\
\hline Cooling Tower(s) & 0.578 & 0.735 & 0.091 & 0.766 & 0.147 & 0.876 & 0.260 & 0.953 & 0.366 \\
\hline Geothermal Well(s) & N/A & 1.218 & 1.218 & 1.218 & 1.218 & 1.218 & 1.218 & 2.436 & 2.436 \\
\hline Total Physical Plant & 20.719 & 23.058 & 2.201 & 23.423 & 3.058 & 25.302 & 5.913 & 28.145 & 8.928 \\
\hline $\begin{array}{l}\text { Construction/Labor } \\
\text { Management }\end{array}$ & 5.939 & 6.610 & 0.631 & 6.714 & 0.876 & 7.253 & 1.695 & 8.068 & 2.559 \\
\hline Total Initial Plant & 26.659 & 29.667 & 2.832 & 30.137 & 3.934 & 32.555 & 7.609 & 36.213 & 11.487 \\
\hline Capital Cost of Power & $\$ 570 / \mathbf{k W}$ & $\$ 625 / \mathrm{kW}$ & $\$ 1924 / \mathrm{kW}$ & $\$ 609 / \mathrm{kW}$ & $\$ 1341 / \mathrm{kW}$ & $\$ 575 / \mathrm{kW}$ & $\$ 932 / \mathrm{kW}$ & $\$ 587 / \mathrm{kW}$ & $\$ 942 / \mathrm{kW}$ \\
\hline
\end{tabular}


Table 3

TIME-DEPENDENT COST FACTORS

\begin{tabular}{|c|c|c|c|}
\hline & Hybrid Cycle & Al1-Geothermal Cycle & Al1-Fossil Cycle \\
\hline Capacity Factor & $85.00 \%$ & $85.00 \%$ & $85.00 \%$ \\
\hline Plant Life & 30.00 years & 30.00 years & 30.00 years \\
\hline Construction Time & 4.00 years & 4.00 years & 4.00 years \\
\hline Bond Interest Rate & $6.00 \%$ & $6.00 \%$ & $6.00 \%$ \\
\hline Inflation Rate & $5.00 \%$ & $5.00 \%$ & $5.00 \%$ \\
\hline O/M Growth Rate & $5.00 \%$ & $5.00 \%$ & $5.00 \%$ \\
\hline Coal Cost Growth Rate & $8.00 \%$ & $8.00 \%$ & $8.00 \%$ \\
\hline Construction Labor Rate & $28.67 \%$ & $28.67 \%$ & $28.67 \%$ \\
\hline Plant $0 / M$ Rate & $10.00 \%$ & $17.00 \%$ & $6.00 \%$ \\
\hline Well $0 / M$ Rate & $17.00 \%$ & $17.00 \%$ & $\mathrm{~N} / \mathrm{A}$ \\
\hline Selsmic Factor & $100.00 \%$ & $100.00 \%$ & $100.00 \%$ \\
\hline Coal Cost ( $\$ /$ Tonne: 1976$)$ & $\$ 21.07$ & $\$ 0.00$ & $\$ 21.07$ \\
\hline $\begin{array}{l}\text { Well Half-Life } \\
\text { Well Replacement Rate }\end{array}$ & $\begin{array}{l}10.00 \text { years } \\
.06697 \text { (wells/yr)/well }\end{array}$ & $\begin{array}{l}10.00 \text { years } \\
.06697 \text { (wells/yr)/well }\end{array}$ & $\begin{array}{l}\text { N/A } \\
\text { N/A }\end{array}$ \\
\hline
\end{tabular}


Table 4

LEVELIZED ANNUAL COSTS EXPRESSED IN MILLS/KWH

\begin{tabular}{|c|c|c|c|c|c|c|c|c|}
\hline \multicolumn{2}{|l|}{ Resource } & \multicolumn{2}{|c|}{$\begin{array}{l}\text { Average Annual } \\
\text { Capital Cost }\end{array}$} & \multicolumn{2}{|c|}{$\begin{array}{c}\text { Ayerage Annual } \\
\text { Coa1 Cost }\end{array}$} & \multicolumn{3}{|c|}{ Busbar Cost } \\
\hline Temperature & $\begin{array}{l}\text { Extracted } \\
\text { Flow Rate } \\
\text { (K1b/Hr) }\end{array}$ & Hybrid & $\begin{array}{l}\text { Double- } \\
\text { Flash }\end{array}$ & Hybrid & $\begin{array}{l}\text { Double- } \\
\text { Flash }\end{array}$ & Hybrid & $\begin{array}{l}\text { Double- } \\
\text { F1ash }\end{array}$ & $\begin{array}{l}\text { Conv. } \\
\text { Coal } \\
\text { Fired }\end{array}$ \\
\hline $428.6^{\circ} \mathrm{K}\left(311.8^{\circ} \mathrm{F}\right)$ & 383.8 & 2.64 & 8.12 & 14.16 & N/A & 24.48 & 72.12 & 20.56 \\
\hline $468.5^{\circ} \mathrm{K}\left(383.7^{\circ} \mathrm{F}\right)$ & 411.0 & 2.57 & 5.66 & 13.59 & N/A & 23.63 & 44.80 & 20.56 \\
\hline $549.8^{\circ} \mathrm{K}\left(530.0^{\circ} \mathrm{F}\right)$ & 470.1 & 2.43 & 3.94 & 11.88 & $\mathrm{~N} / \mathrm{A}$ & 21.33 & 26.24 & 20.56 \\
\hline $587.8^{\circ} \mathrm{K}\left(598.4^{\circ} \mathrm{F}\right)$ & 510.2 & 2.48 & 3.97 & 10.90 & N/A & 20.90 & 26.98 & 20.56 \\
\hline
\end{tabular}


resource flow rates investigated. Thus, an important economic conclusion is that at low flow rates, and therefore low risk of resource depletion, the hybrid cycle generates enough power to increase the likelihood that development of a geothermal resource is economically justifiable.

Table 4 indicates that from the point of view of total distributed cost of power (mills/kWh), the hybrid cycle is capable of cutting the cost of power by a factor of two or three when compared to low flow rate doubleflash units operating at low to moderate temperatures $\left(429^{\circ} \mathrm{K}\right.$ to $\left.469^{\circ} \mathrm{K}\right)$. Although the hybrid cost of power is not less than the fossil-fired cost of power, the values are so close that the hybrid is competitive, and on a site-specific basis might demonstrate an economic advantage over all fossil units, even with fossil fuel costs in the order of $\$ 20 /$ ton $(\$ .85 /$ million BTU).

With the development of thermodynamic figures of merit and cost estimates for relative economic performance under the conditions investigated, we can now proceed to develop information about the overall benefit of alternative cycles. As mentioned above, thermodynamic performance of the hybrid cycle is defined as

$$
F_{1}=\frac{P_{H}}{P_{F}+P_{g}}
$$

where

$P_{H}$ is the power developed by the $2 \emptyset$ hybrid cycle, $P_{F}$ is the power developed by the fossil-fired cycle, $\mathrm{P}_{\mathrm{g}}$ is the power developed by the geothermal cycle. A similar comparison of cycles could be conducted to develop an economic figure of merit relating the capital cost of power for the hybrid cycle to the sum of the capital costs of power for the stand-alone fossil and geothermal units. However, the weighting of contributory portions of capital cost must be considered. Thus, an economic figure of merit based on capital cost can be defined as 


$$
F_{\varepsilon}=\frac{\frac{P_{h}}{C_{c_{h}}}}{\frac{P_{f}}{C_{c_{f}}}+\frac{P_{g}}{C_{c_{g}}}}
$$

where

$c_{c_{h}}$ is the capital cost of power of the hybrid unit expressed in $(\$ / \mathrm{KW})$,

$C_{c_{f}}$ is the capital cost of power of the fossil unit expressed in $(\$ / K W)$,

$C_{c}$ is the capital cost of power of the geothermal unit expressed $\mathrm{g}$ in $(\$ / \mathrm{KW})$.

$F_{\varepsilon}$ represents a weighted ratio of capital cost for alternative mechanisms of energy utilization. Since the numerator and each term in the denominator represent benefit-cost ratios for the alternative individual power plants, $F_{E}$ is an index of utility for investment capital.

A similar figure of merit can be developed which relates the distributed cost of power, including amortized capital cost and $0 / M$ costs. This general economic figure of merit can be defined as

$$
F_{\xi}=\frac{\frac{P_{h}}{C_{d_{h}}}}{\frac{P_{f}}{C_{d_{f}}}+\frac{P_{g}}{C_{d_{g}}}}
$$

where

$c_{d}$ is the distributed cost of power at the busbar for the hybrid h unit (mills/kWh),

$c_{d}$ is the distributed cost of power at the busbar for the fossil unit (mills/kWh),

$c_{d}$ is the distributed cost of power at the busbar for the geothermal $\mathrm{g}$ unit (mills/kWh). 
Because of the relatively low power levels developed by the double-flash units at the flow rates investigated (see Table 1), and because of the prohibitive cost of power of the double-flash units (see Table 4), development of the stand-alone geothermal power plant may be considered economically unjustifiable. Consideration of alternative cycles on the basis of economics in this case must compare the weighted cost of power for the fossil-fired unit to the weighted cost of power for the hybrid unit. This figure of merit is a degenerate case of the expression for $F_{\xi}$, and can be written as

$$
F_{\lambda}=\frac{\frac{P_{h}}{C_{d_{h}}}}{\frac{P_{f}}{C_{d_{f}}}} \text {. }
$$

The economic figures of merit described above, which will vary on a sitespecific basis, have been evaluated for illustration purposes using data developed from this study. Values for figures of merit are listed in Table 5, along with appropriate factors which are reproduced for convenience. Variations in figures of merit as a function of resource temperature are shown in Fig. 9.

As was mentioned earller, quantitative cost of power is a significant measure of the benefit to be derived by the development of alternative cycles. However, a second measure of benefit must include risk. Although ordinary business risk can be quantified in capital investment decisions, risk assoctated with geothermal resource life is largely unknown. Since the fluid extraction rates required for operation of the hybrid cycle are significantly less than the rates required for economic operation of flashing-type systems, the risk of resource depletion is reduced by using the hybrid.

The actual merit of the hybrid cycle must be a subjective evaluation that includes the thermodynamic figure of merit shown in Fig. 7 and the appropriate economic figure of merit shown in Fig. 9. 
Table 5

ECONOMIC FACTORS AND FIGURES OF MERIT

$\begin{array}{lcccc}\mathrm{T}_{\mathrm{GEO}}\left({ }^{\circ} \mathrm{K}\right) & 428 & 468 & 550 & 589 \\ \mathrm{C}_{\mathrm{c}_{\mathrm{f}}(\$ / \mathrm{KW})} & 570 & 570 & 570 & 570 \\ \mathrm{C}_{\mathrm{c}_{\mathrm{g}}(\$ / \mathrm{KW})} & 1924 & 1341 & 932 & 942 \\ \mathrm{C}_{\mathrm{C}_{\mathrm{h}}(\$ / \mathrm{KW})} & 625 & 609 & 575 & 587 \\ \mathrm{C}_{\mathrm{d}_{\mathrm{f}}\left(\frac{\mathrm{mills}}{\mathrm{kWh}}\right)} & 20.56 & 20.56 & 20.56 & 20.56 \\ \mathrm{C}_{\mathrm{g}}\left(\frac{\mathrm{mills}}{\mathrm{kWh}}\right) & 72.12 & 44.80 & 26.24 & 26.98 \\ \mathrm{C}_{\mathrm{d}_{\mathrm{h}}\left(\frac{\mathrm{mills}}{\mathrm{kWh}}\right)} & 24.48 & 23.63 & 21.33 & 20.90 \\ \mathrm{P}_{\mathrm{f}}(\mathrm{MW}) & 46.80 & 46.80 & 46.80 & 46.80 \\ \mathrm{P}_{\mathrm{g}}(\mathrm{MW}) & 1.47 & 2.93 & 8.16 & 12.20 \\ \mathrm{P}_{\mathrm{h}}(\mathrm{MW}) & 47.48 & 49.49 & 56.59 & 61.70 \\ \mathrm{~F}_{\varepsilon} & 0.92 & 0.96 & 1.08 & 1.11 \\ \mathrm{~F}_{\xi} & 0.84 & 0.89 & 1.03 & 1.08 \\ \mathrm{~F}_{\lambda} & 0.84 & 0.92 & 1.17 & 1.30\end{array}$




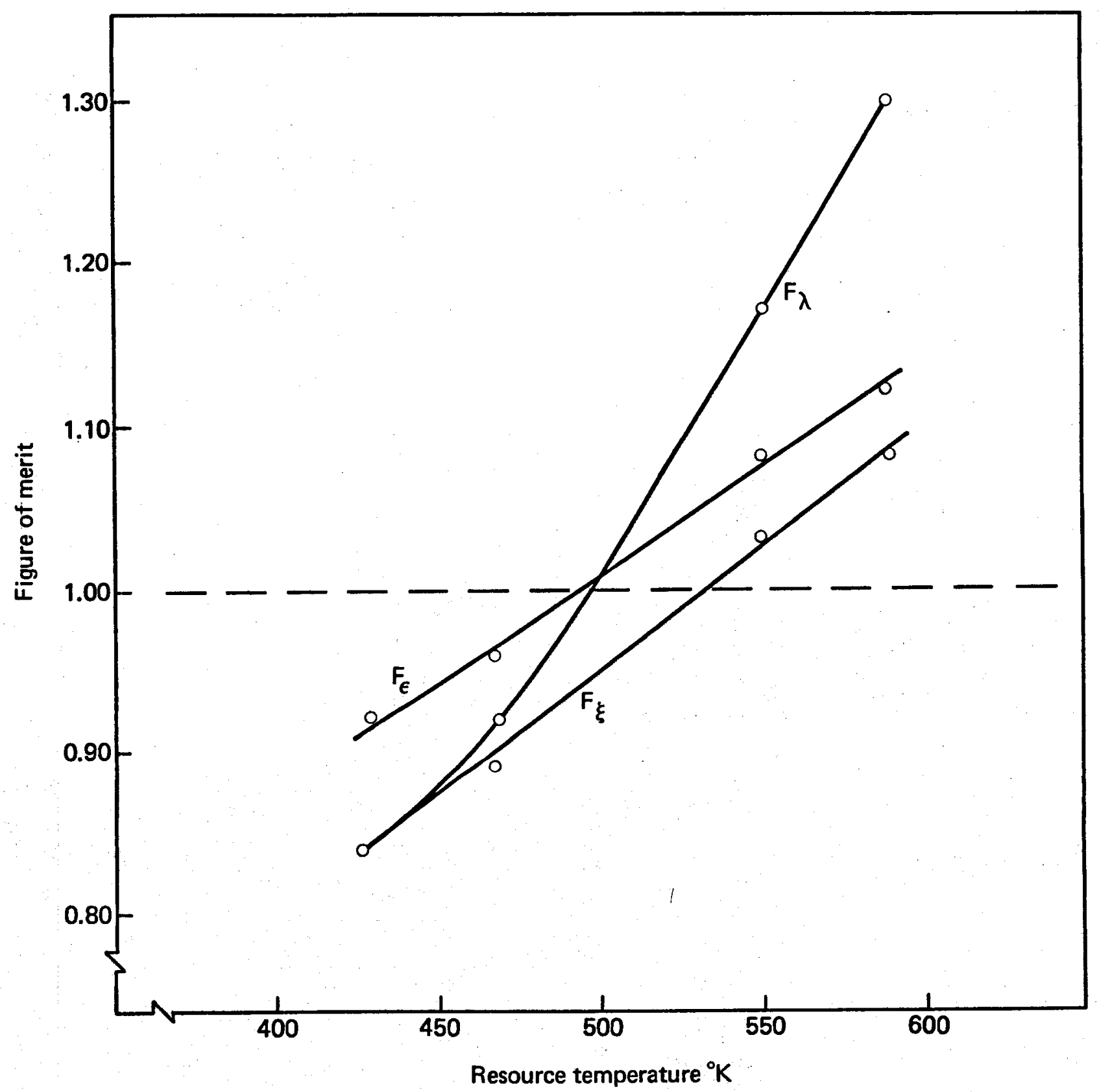

Fig. 9--Economic figure of merit as a function of hydrothermal resource temperature 


\section{REFERENCES}

1. DiPippo, R, J. Kestin, and H. E. Khalifa, Hybrid Fossil-Geothermal Power Plants, Providence, Rhode Island, 1977.

2. Anno, G. H., M. A. Dore, R. L. Grijalva, G. D. Lang, and F. J. Thomas, Site-Specific Analysis of Hybrid Geothermal/Fossil Power Plants, PSR Report 705, Pacific-Sierra Research Corporation, Santa Monica, California, April 1977.

3. Anno, G. H. and M. A. Dore, Pacific-Sierra Research Corporation; G. L. Simay, City of Burbank; Continuing Site-Specific and Design Analysis of Hybrid Geothermal/Fossil Power Plants, June 1978.

4. DiPippo, R., H. E. Khalifa, R. J. Correa, and J. Kestin, Fossil Superheating in Geothermal Steam Power Plants, Brown University, Providence, Rhode Island, March 1978.

5. Gabrie11i, F., F. R. Henry, R. C. Keirstead, J. A. Ray, and W. R. Sylvester, "Prevent corrosion and deposition problems in highpressure boilers," Power, Ju1y 1978.

6. Rivers, H. M., "Concentrating films: Their role in boiler scale and corrosion problems," Combustion, April 1952. 


\section{Appendix A \\ THERMODYNAMIC PERFORMANCE CHARACTERISTICS}

Optimization of the various cycles modeled was done using computer program GEOTHMF, a modified version of the computer program GEOTHM, developed at Lawrence Berkeley Laboratory. The state-point conditions and equipment-performance parameters that were allowed to vary are described below. Our intent was to choose those parameters for numerical optimization that could most affect cycle performance. The maximum temperature limit at which the hybrid and fossil-fired cycle could operate was an optimizable parameter but was not permitted to exceed an upper bound. In each case the upper bound was reached, as one might expect. Optimizable parameters which varied in this study are described below for each ycle. Refer to Figs. A1, A2, and A3 for cycle coordinate locations of the various optimizable parameters. State points and flow rates for the cycles are listed in Tables A1 through A27. T-S diagrams are shown on Figs. A4 through A8.

CYCLE CONFIGURATION--2ø: One-Stage Separation with Fossil Topping (See Fig. Al): OPT IMIZABLES :

SHOTEMP $(2,3)$ flue gas superheater outlet temperature.

PINCHWAWA $(2,10)(1,15)$ pinch point for the water wa11 bulk fluid temperature/flue gas in the steam generator.

FLWSPLT Split ratio for mass flow rate demanded by the steam generator. This parameter allows second-law optimization of superheater/steam generator efficiency tradeoff.

$\mathrm{H}(3,10)$ Enthalpy of working flutd at the exit from the steam generator. Upper limit on enthalpy simulated maximum achievable quality of between 75 and 95 percent.

PGEOPOT Pressure out of the boiler feed pump $(2,10)$. This pressure controls where the cycle crosses the dome.

HYTROUT Pressure out of the ancillary hydraulic turbine. This pressure was slaved to exceed the extraction wellhead pressure $(1,10)$ by three bars. 


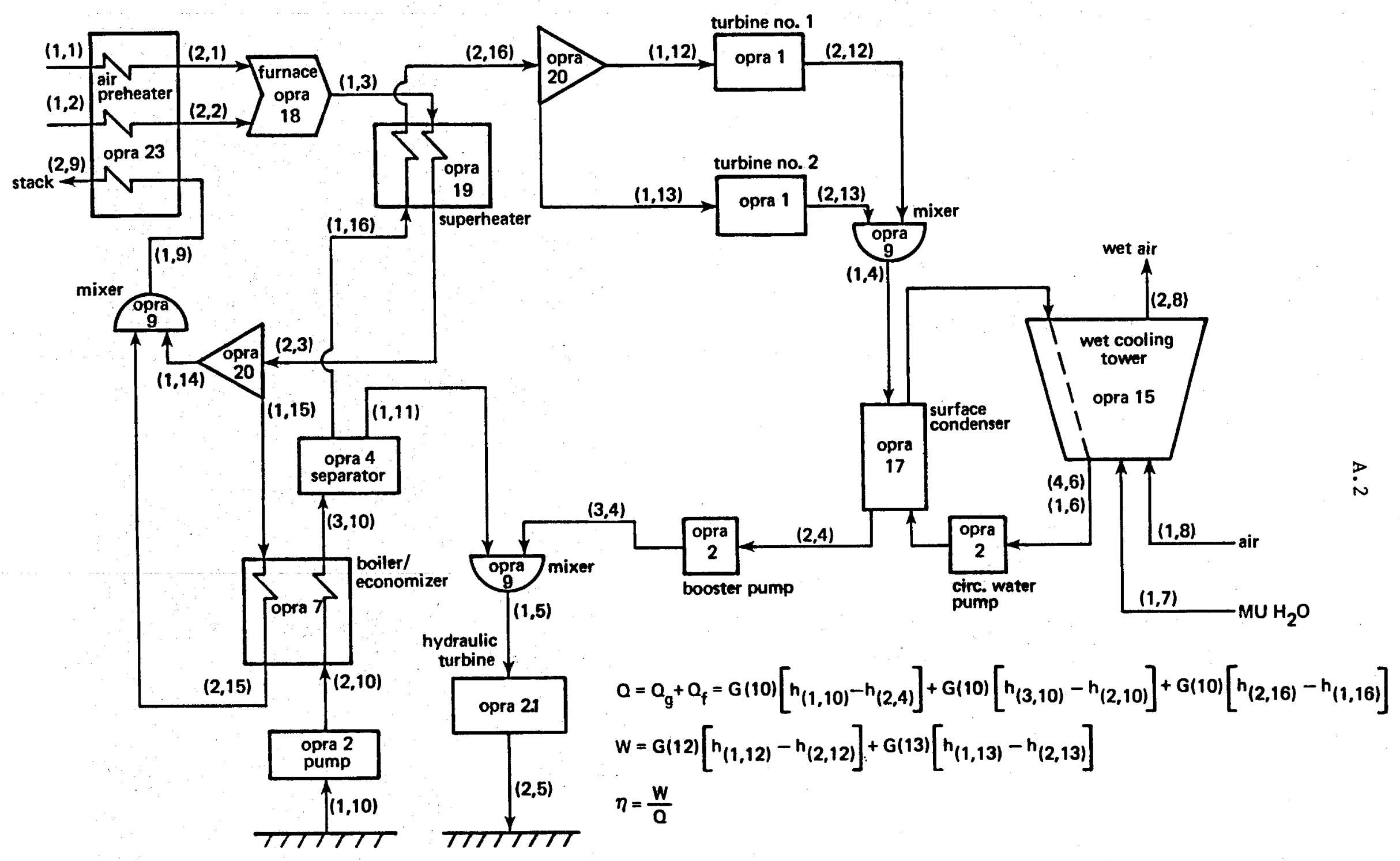

Fig. Al--2ø configuration: One-stage separation with fossil-fuel topping 


\section{A. 3}

CYCLE CONFIGURATION--DOUBLE-FLASH: Two-Stage Separation, A11-Geothermal (See Fig. A2):

OPTIMIZABLES :

PVALVE Pressure at $(2,10)$, just upstream of the first-phase separator.

PRESSEP Pressure at $(2,1)$, just upstream of the second-phase separator.

The two-separator pressure-optimizable parameters yielded results which support the notion that temperature drop between stages is constant and equal to source temperature minus sink temperature divided by the number of stages plus one. However, by imposing a hard constraint on turbine exit quality such that $Q \geq 0.7$, separator pressures vary somewhat from the equal-drop rule.

CYCLE CONFIGURATION--ALL-FOSSIL: One Reheat Double Regeneration (See Fig. A3):

\section{OPTIMIZABLES :}

PBFPOUT Boiler feed-pump discharge pressure $(5,4)$. This pressure determines boiling temperature in the $S / G$.

PNCHRSH Pinch point in the reheat section of the boiler.

PTRBINT Pressure into the intermediate pressure turbine $(2,6)$.

PTRBLO Pressure into the low-pressure turbine $(3,6)$.

FLSPL1 The flow split ratio which votes on the split between main steam to the IP turbine and extraction steam to the feedwater heater.

FLSPL2 The flow split ratio which votes on the split between main steam to the LP turbine and extraction steam to the mixer, which ultimately provides extraction steam to the condensate heater.

PBFBPOT Pressure out of the botler-feed booster pump. This pressure affects the degree of condensate regeneration that can be accomplished $(2,4)$. 


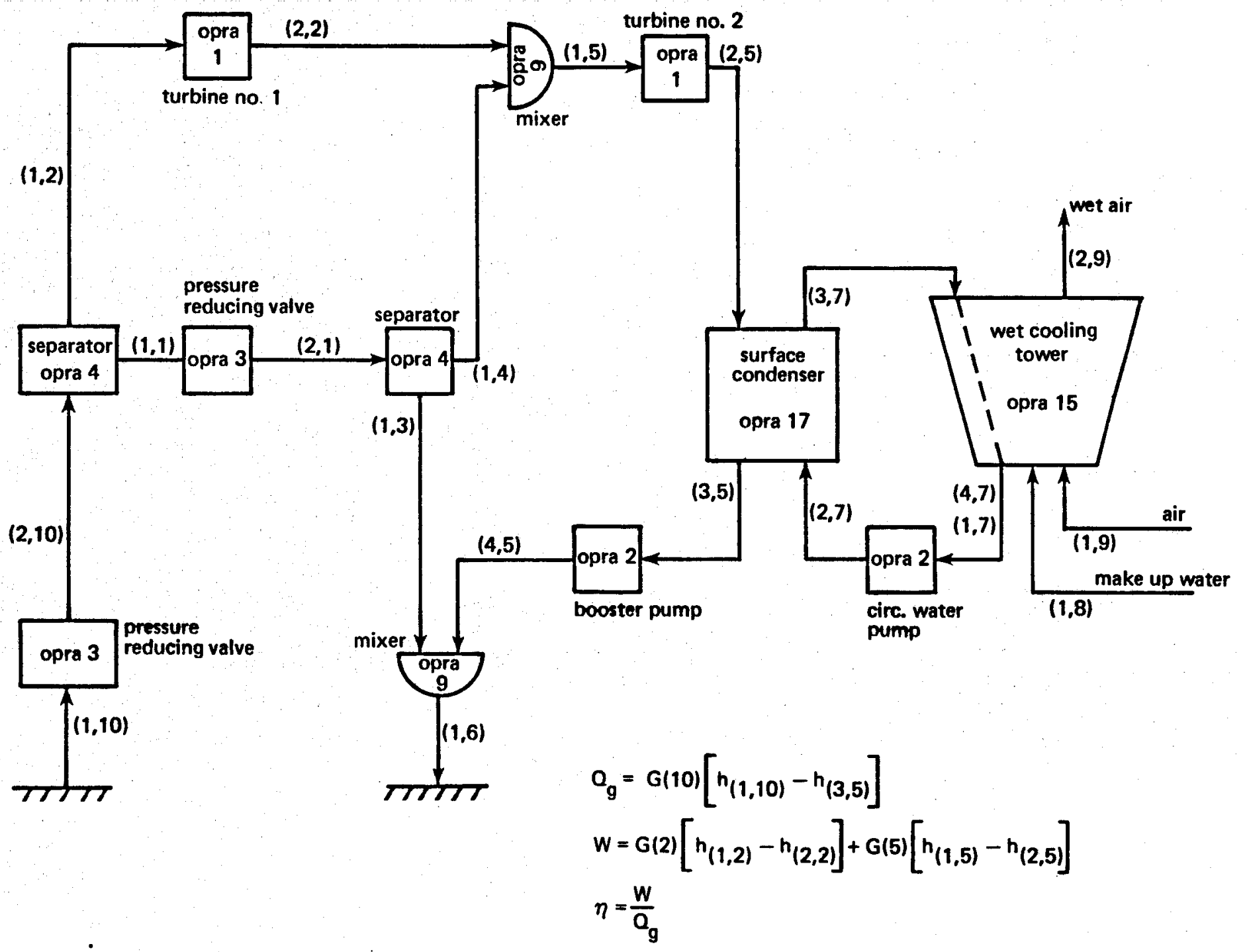

Fig. A2--Double separation flash cycle 


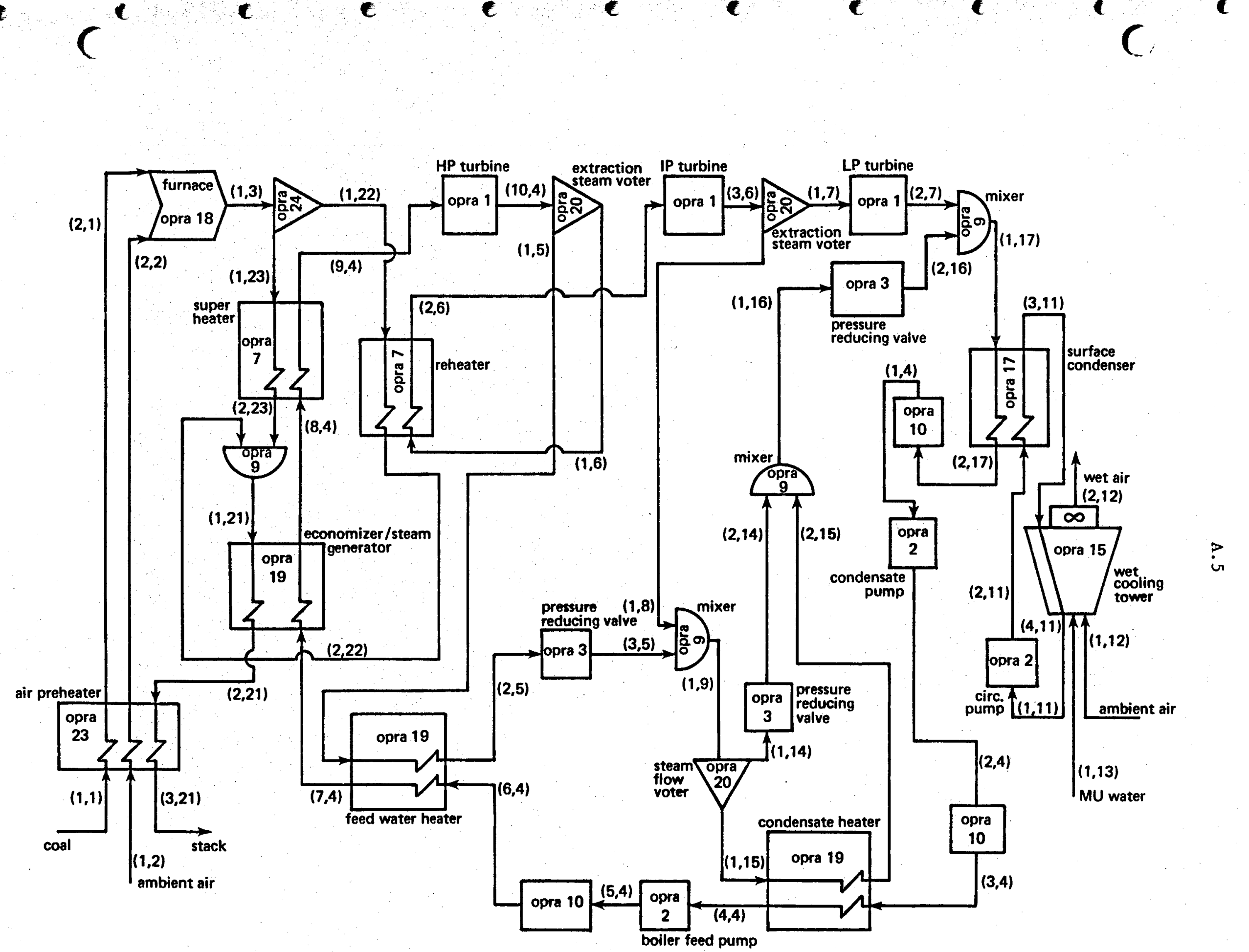

Fig. A3--One reheat: Double regeneration all-foss11 cycle 
TB/E-SH Steam temperature between the boller/economizer and the superheater $(8,4)$. This optimizable parameter together with PBFPOUT provides the code with the capability of independently varying the size of the superheater and reheater without decreasing economizer performance.

TOUTCT Temperature of wet air rejected from the cooling tower. This optimizable was frozen for other cycles $(2,12)$.

PNCHSH Superheater pinch point.

PNCHCON Condenser pinch point.

TFWH-1 Extraction steam temperature downstream of the feedwater heater $(2,5)$.

FLSPL3 Extraction steam voter. This optimizable parameter allows high- and low-pressure extraction steam flow rates to be optimized independently. 


\section{A. 7}

Table A1

STATE POINTS FOR THE 20 HYBRID CYCLE AT RESOURCE TEMPERATURE $=429^{\circ} \mathrm{K}\left(312^{\circ} \mathrm{F}\right)$

\begin{tabular}{rrrrrrrr}
\hline & & T & \multicolumn{1}{c}{ P } & \multicolumn{1}{c}{ H } & \multicolumn{1}{c}{ S } & \\
K & L & (DEG K) & (BAR) & (J/G) & $(\mathrm{J} / \mathrm{GK})$ & \multicolumn{1}{c}{$\mathrm{Q}$} \\
\hline 1 & 1 & 307.604 & 0.873 & 9.476 & 0.070 & 5.000 \\
2 & 1 & 480.000 & 0.873 & 370.276 & 2.744 & -2.000 \\
1 & 2 & 307.604 & 0.873 & 9.476 & 0.070 & 5.000 \\
2 & 2 & 480.000 & 0.873 & 182.468 & 0.517 & 5.000 \\
1 & 3 & 2324.444 & 0.873 & 2595.813 & 2.668 & 5.000 \\
2 & 3 & 1785.315 & 0.873 & 1905.150 & 2.330 & 5.000 \\
1 & 4 & 325.572 & 0.140 & 2204.966 & 6.788 & 0.880 \\
2 & 4 & 325.572 & 0.140 & 114.564 & 0.367 & 0.000 \\
3 & 4 & 330.090 & 149.950 & 133.446 & 0.379 & -1.000 \\
1 & 5 & 352.124 & 149.950 & 225.712 & 0.652 & -1.000 \\
2 & 5 & 347.809 & 8.600 & 207.615 & 0.641 & -1.000 \\
1 & 6 & 301.330 & 0.873 & 13.294 & 0.044 & -1.000 \\
2 & 6 & 301.443 & 4.700 & 13.765 & 0.044 & -1.000 \\
3 & 6 & 320.572 & 3.700 & 93.673 & 0.302 & -1.000 \\
4 & 6 & 301.330 & 0.873 & 13.294 & 0.044 & -1.000 \\
1 & 7 & 299.827 & 0.873 & 7.010 & 0.023 & -1.000 \\
1 & 8 & 307.604 & 0.873 & 31.094 & 1.357 & 5.000 \\
2 & 8 & 311.000 & 0.873 & 137.512 & 0.081 & 5.000 \\
1 & 9 & 443.392 & 0.873 & 186.051 & 0.546 & 5.000 \\
2 & 9 & 320.992 & 0.873 & 29.248 & 0.132 & 5.000 \\
1 & 10 & 428.611 & 5.500 & 550.956 & 1.530 & 0.000 \\
2 & 10 & 433.172 & 149.950 & 570.762 & 1.539 & -1.000 \\
3 & 10 & 615.333 & 149.950 & 2436.670 & 4.830 & 0.933 \\
1 & 11 & 615.333 & 149.950 & 1505.451 & 3.317 & 0.000 \\
2 & 11 & 615.333 & 149.950 & 1505.451 & 3.317 & 0.000 \\
1 & 12 & 809.312 & 149.450 & 3307.502 & 6.110 & 2.000 \\
2 & 12 & 325.572 & 0.140 & 2204.966 & 6.788 & 0.880 \\
1 & 13 & 809.312 & 149.450 & 3307.502 & 6.110 & 2.000 \\
2 & 13 & 325.572 & 0.140 & 2204.966 & 6.788 & 0.880 \\
1 & 14 & 1785.315 & 0.873 & 1905.150 & 2.330 & 5.000 \\
1 & 15 & 1785.315 & 0.873 & 1905.150 & 2.330 & 5.000 \\
2 & 15 & 443.249 & 0.873 & 185.867 & 0.545 & 5.000 \\
1 & 16 & 615.333 & 149.950 & 2503.809 & 4.939 & 1.000 \\
\hline & 16 & 809.312 & 149.450 & 3307.502 & 6.110 & 2.000 \\
\hline & & & & & & \\
\hline
\end{tabular}


Table A2

STATE POINTS FOR THE $2 \emptyset$ HYBRID CYCLE AT RESOURCE TEMPERATURE $=312^{\circ} \mathrm{F}\left(429^{\circ} \mathrm{K}\right)$

\begin{tabular}{|c|c|c|c|c|c|c|}
\hline $\mathbf{K}$ & $\mathbf{L}$ & $\frac{T}{\text { (DEG F) }}$ & $\begin{array}{c}P \\
\text { (PSIA) }\end{array}$ & $\begin{array}{c}\mathrm{H} \\
(\mathrm{BTU} / \mathrm{LB})\end{array}$ & $\begin{array}{c}S \\
(B T U / F-L B)\end{array}$ & $\mathbf{Q}$ \\
\hline $\begin{array}{l}1 \\
2\end{array}$ & $\begin{array}{l}1 \\
1\end{array}$ & $\begin{array}{r}93.999 \\
404.312\end{array}$ & $\begin{array}{l}12.662 \\
12.662\end{array}$ & $\begin{array}{r}49.078 \\
204.234\end{array}$ & $\begin{array}{l}0.106 \\
0.745\end{array}$ & $\begin{array}{r}5.000 \\
-2.000\end{array}$ \\
\hline $\begin{array}{l}1 \\
2\end{array}$ & $\begin{array}{l}2 \\
2\end{array}$ & $\begin{array}{r}93.999 \\
404.312\end{array}$ & $\begin{array}{l}12.662 \\
12.662\end{array}$ & $\begin{array}{r}49.078 \\
123.471\end{array}$ & $\begin{array}{l}0.106 \\
0.213\end{array}$ & $\begin{array}{l}5.000 \\
5.000\end{array}$ \\
\hline $\begin{array}{l}1 \\
2\end{array}$ & $\begin{array}{l}3 \\
3\end{array}$ & $\begin{array}{l}3724.312 \\
2753.879\end{array}$ & $\begin{array}{l}12.662 \\
12.662\end{array}$ & $\begin{array}{r}1161.290 \\
864.282\end{array}$ & $\begin{array}{l}0.727 \\
0.646\end{array}$ & $\begin{array}{l}5.000 \\
5.000\end{array}$ \\
\hline $\begin{array}{l}1 \\
2 \\
3\end{array}$ & $\begin{array}{l}4 \\
4 \\
4\end{array}$ & $\begin{array}{l}126.342 \\
126.342 \\
134.474\end{array}$ & $\begin{array}{r}2.031 \\
2.031 \\
2174.846\end{array}$ & $\begin{array}{r}993.212 \\
94.269 \\
102.389\end{array}$ & $\begin{array}{l}1.711 \\
0.177 \\
0.180\end{array}$ & $\begin{array}{r}0.880 \\
0.000 \\
-1.000\end{array}$ \\
\hline $\begin{array}{l}1 \\
2\end{array}$ & $\begin{array}{l}5 \\
5\end{array}$ & $\begin{array}{l}174.135 \\
166.368\end{array}$ & $\begin{array}{r}2174.846 \\
124.733\end{array}$ & $\begin{array}{l}142.067 \\
134.285\end{array}$ & $\begin{array}{l}0.245 \\
0.243\end{array}$ & $\begin{array}{l}-1.000 \\
-1.000\end{array}$ \\
\hline $\begin{array}{l}1 \\
2 \\
3 \\
4\end{array}$ & $\begin{array}{l}6 \\
6 \\
6 \\
6\end{array}$ & $\begin{array}{r}82.706 \\
82.909 \\
117.342 \\
82.706\end{array}$ & $\begin{array}{l}12.662 \\
68.168 \\
53.664 \\
12.662\end{array}$ & $\begin{array}{l}50.720 \\
50.923 \\
85.286 \\
50.720\end{array}$ & $\begin{array}{l}0.100 \\
0.100 \\
0.162 \\
0.100\end{array}$ & $\begin{array}{l}-1.000 \\
-1.000 \\
-1.000 \\
-1.000\end{array}$ \\
\hline 1 & 7 & 80.001 & 12.662 & 48.018 & 0.095 & -1.000 \\
\hline $\begin{array}{l}1 \\
2\end{array}$ & $\begin{array}{l}8 \\
8\end{array}$ & $\begin{array}{r}93.999 \\
100.112\end{array}$ & $\begin{array}{l}12.662 \\
12.662\end{array}$ & $\begin{array}{r}58.375 \\
104.138\end{array}$ & $\begin{array}{l}0.414 \\
0.109\end{array}$ & $\begin{array}{l}5.000 \\
5.000\end{array}$ \\
\hline $\begin{array}{l}1 \\
2\end{array}$ & $\begin{array}{l}9 \\
9\end{array}$ & $\begin{array}{l}338.418 \\
118.097\end{array}$ & $\begin{array}{l}12.662 \\
12.662\end{array}$ & $\begin{array}{r}125.011 \\
57.580\end{array}$ & $\begin{array}{l}0.220 \\
0.121\end{array}$ & $\begin{array}{l}5.000 \\
5.000\end{array}$ \\
\hline $\begin{array}{l}1 \\
2 \\
3\end{array}$ & $\begin{array}{l}10 \\
10 \\
10\end{array}$ & $\begin{array}{l}311.812 \\
320.022 \\
647.911\end{array}$ & $\begin{array}{r}79.771 \\
2174.846 \\
2174.846\end{array}$ & $\begin{array}{r}281.933 \\
290.450 \\
1092.853\end{array}$ & $\begin{array}{l}0.455 \\
0.457 \\
1.243\end{array}$ & $\begin{array}{r}0.000 \\
-1.000 \\
0.933\end{array}$ \\
\hline $\begin{array}{l}1 \\
2\end{array}$ & $\begin{array}{l}11 \\
11\end{array}$ & $\begin{array}{l}647.911 \\
647.911\end{array}$ & $\begin{array}{l}2174.846 \\
2174.846\end{array}$ & $\begin{array}{l}692.397 \\
692.397\end{array}$ & $\begin{array}{l}0.882 \\
0.882\end{array}$ & $\begin{array}{l}0.000 \\
0.000\end{array}$ \\
\hline $\begin{array}{l}1 \\
1\end{array}$ & $\begin{array}{l}12 \\
12\end{array}$ & $\begin{array}{l}997.074 \\
126.342\end{array}$ & $\begin{array}{r}2167.594 \\
2.031\end{array}$ & $\begin{array}{r}1467.340 \\
993.212\end{array}$ & $\begin{array}{l}1.549 \\
1.711\end{array}$ & $\begin{array}{l}2.000 \\
0.880\end{array}$ \\
\hline $\begin{array}{l}1 \\
2\end{array}$ & $\begin{array}{l}13 \\
13\end{array}$ & $\begin{array}{l}997.074 \\
126.342\end{array}$ & $\begin{array}{r}2167.594 \\
2.031\end{array}$ & $\begin{array}{r}1467.340 \\
993.212\end{array}$ & $\begin{array}{l}1.549 \\
1.711\end{array}$ & $\begin{array}{l}2.000 \\
0.880\end{array}$ \\
\hline 1 & 14 & 2753.879 & 12.662 & 864.282 & 0.646 & 5.000 \\
\hline $\begin{array}{l}1 \\
2\end{array}$ & $\begin{array}{l}15 \\
15\end{array}$ & $\begin{array}{r}2753.879 \\
338.159\end{array}$ & $\begin{array}{l}12.662 \\
12.662\end{array}$ & $\begin{array}{l}864.282 \\
124.932\end{array}$ & $\begin{array}{l}0.646 \\
0.220\end{array}$ & $\begin{array}{l}5.000 \\
5.000\end{array}$ \\
\hline $\begin{array}{l}1 \\
2\end{array}$ & $\begin{array}{l}16 \\
16\end{array}$ & $\begin{array}{l}647.911 \\
997.074\end{array}$ & $\begin{array}{l}2174.846 \\
2167.594\end{array}$ & $\begin{array}{l}1121.725 \\
1467.340\end{array}$ & $\begin{array}{l}1.269 \\
1.549\end{array}$ & $\begin{array}{l}1.000 \\
2.000\end{array}$ \\
\hline
\end{tabular}


Table A3

STREAM FLOW RATES FOR THE $2 \emptyset$ HYBRID CYCLE AT RESOURCE TEMPERATURE $=429^{\circ} \mathrm{K}\left(312^{\circ} \mathrm{F}\right)$

\begin{tabular}{rrrrc}
\hline \multicolumn{1}{c}{$\begin{array}{c}\text { G } \\
\text { L }\end{array}$} & \multicolumn{1}{c}{$\begin{array}{c}\text { G } \\
(\mathrm{KLEC})\end{array}$} & \multicolumn{1}{c}{$\begin{array}{c}\text { Fluid } \\
\text { Number }\end{array}$} & $\begin{array}{c}\text { Fluid } \\
\text { Description }\end{array}$ \\
\hline 1 & 5.03992 & 40.00000 & 7 & Coal \\
2 & 48.81438 & 387.42217 & 7 & Atmospheric Air \\
3 & 53.85430 & 427.42217 & 6 & Flue Gases \\
4 & 46.28034 & 367.31041 & 1 & Water \\
5 & 49.61708 & 393.79287 & 1 & Water \\
6 & 1210.70145 & 9608.90154 & 1 & Water \\
7 & 38.34932 & 304.36472 & 1 & Water \\
8 & 917.96366 & 7285.54713 & 7 & Atmospheric A1r \\
9 & 53.85430 & 427.42217 & 6 & Flue Gases \\
10 & 49.61708 & 393.79287 & 1 & Water \\
11 & 3.33673 & 26.48246 & 1 & Water \\
12 & 23.14017 & 183.65520 & 1 & Water \\
13 & 23.14017 & 183.65520 & 1 & Water \\
14 & 0.00575 & 0.04567 & 6 & Flue Gases \\
15 & 53.84854 & 427.37650 & 6 & Flue Gases \\
16 & 46.28034 & 367.31041 & 1 & Water \\
\hline
\end{tabular}


Table A4

STATE POINTS FOR THE DOUBLE-FLASH CYCLE AT RESOURCE TEMPERATURE $=429^{\circ} \mathrm{K}\left(312^{\circ} \mathrm{F}\right)$

\begin{tabular}{rrrrrrr}
\hline $\mathrm{K}$ & $\mathrm{L}$ & $\begin{array}{c}\mathrm{T} \\
\text { (DEG K) }\end{array}$ & $\begin{array}{c}\mathrm{P} \\
\text { (BAR) }\end{array}$ & $\begin{array}{c}\mathrm{H} \\
(\mathrm{J} / \mathrm{G})\end{array}$ & $\begin{array}{c}\mathrm{S} \\
(\mathrm{J} / \mathrm{GK})\end{array}$ & $\mathrm{Q}$ \\
\hline 1 & 1 & 398.703 & 2.363 & 422.457 & 1.220 & 0.000 \\
2 & 1 & 364.645 & 0.744 & 422.457 & 1.238 & 0.063 \\
1 & 2 & 398.703 & 2.363 & 2608.320 & 6.702 & 1.000 \\
2 & 2 & 364.645 & 0.744 & 2444.537 & 6.783 & 0.951 \\
1 & 3 & 364.645 & 0.744 & 278.325 & 0.842 & 0.000 \\
1 & 4 & 364.645 & 0.744 & 2557.024 & 7.091 & 1.000 \\
1 & 5 & 364.645 & 0.744 & 2501.136 & 6.938 & 0.975 \\
2 & 5 & 325.572 & 0.140 & 2292.706 & 7.057 & 0.916 \\
3 & 5 & 325.572 & 0.140 & 114.564 & 0.367 & 0.000 \\
4 & 5 & 325.591 & 0.744 & 114.641 & 0.367 & -1.000 \\
1 & 6 & 360.040 & 0.744 & 258.957 & 0.789 & -1.000 \\
2 & 6 & 360.277 & 8.500 & 259.952 & 0.789 & -1.000 \\
1 & 7 & 301.330 & 0.873 & 13.294 & 0.044 & -1.000 \\
2 & 7 & 301.443 & 4.700 & 13.765 & 0.044 & -1.000 \\
3 & 7 & 324.405 & 3.700 & 109.686 & 0.351 & -1.000 \\
1 & 8 & 301.330 & 0.873 & 13.294 & 0.044 & -1.000 \\
1 & 9 & 307.604 & 0.873 & 31.094 & 1.357 & 5.000 \\
2 & 9 & 311.000 & 0.873 & 137.512 & 0.081 & 5.000 \\
1 & 10 & 428.611 & 5.500 & 550.956 & 1.530 & 0.000 \\
2 & 10 & 398.703 & 2.363 & 550.956 & 1.542 & 0.059 \\
\hline & & & & & &
\end{tabular}


Table A5

STATE POINTS FOR THE DOUBLE-FLASH CYCLE AT RESOURCE TEMPERATURE $=312^{\circ} \mathrm{F}\left(429^{\circ} \mathrm{K}\right)$

\begin{tabular}{|c|c|c|c|c|c|c|}
\hline $\mathbf{K}$ & L & $\stackrel{T}{\text { (DEG F) }}$ & $\underset{\text { (PSIA) }}{\mathrm{P}}$ & $\underset{(B T U / L B)}{H}$ & $\begin{array}{c}S \\
(B T U / F-L B)\end{array}$ & $Q$ \\
\hline $\begin{array}{l}1 \\
2\end{array}$ & $\begin{array}{l}1 \\
1\end{array}$ & $\begin{array}{l}257.977 \\
196.674\end{array}$ & $\begin{array}{l}34.267 \\
10.797\end{array}$ & $\begin{array}{l}226.674 \\
226.674\end{array}$ & $\begin{array}{l}0.381 \\
0.385\end{array}$ & $\begin{array}{l}0.000 \\
0.063\end{array}$ \\
\hline$\frac{1}{2}$ & $\begin{array}{l}2 \\
2\end{array}$ & $\begin{array}{l}257.977 \\
196.674\end{array}$ & $\begin{array}{l}34.267 \\
10.797\end{array}$ & $\begin{array}{r}1166.668 \\
.1096 .236\end{array}$ & $\begin{array}{l}1.691 \\
1.710\end{array}$ & $\begin{array}{l}1.000 \\
0.951\end{array}$ \\
\hline 1 & 3 & 196.674 & 10.797 & 164.692 & 0.291 & 0.000 \\
\hline 1 & 4 & 196.674 & 10.797 & 1144.609 & 1.784 & 1.000 \\
\hline $\begin{array}{l}1 \\
2 \\
3 \\
4\end{array}$ & $\begin{array}{l}5 \\
5 \\
5 \\
5\end{array}$ & $\begin{array}{l}196.674 \\
126.342 \\
126.342 \\
126.376\end{array}$ & $\begin{array}{r}10.797 \\
2.031 \\
2.031 \\
10.797\end{array}$ & $\begin{array}{r}1120.575 \\
1030.944 \\
94.269 \\
94.302\end{array}$ & $\begin{array}{l}1.747 \\
1.775 \\
0.177 \\
0.177\end{array}$ & $\begin{array}{r}0.975 \\
0.916 \\
0.000 \\
-1.000\end{array}$ \\
\hline $\begin{array}{l}1 \\
2\end{array}$ & $\begin{array}{l}6 \\
6\end{array}$ & $\begin{array}{l}188.384 \\
188.810\end{array}$ & $\begin{array}{r}10.797 \\
123.282\end{array}$ & $\begin{array}{l}156.363 \\
156.791\end{array}$ & $\begin{array}{l}0.278 \\
0.278\end{array}$ & $\begin{array}{l}-1.000 \\
-1.000\end{array}$ \\
\hline $\begin{array}{l}1 \\
2 \\
3\end{array}$ & $\begin{array}{l}7 \\
7 \\
7\end{array}$ & $\begin{array}{r}82.706 \\
82.909 \\
124.241\end{array}$ & $\begin{array}{l}12.662 \\
68.168 \\
53.664\end{array}$ & $\begin{array}{l}50.720 \\
50.923 \\
92.172\end{array}$ & $\begin{array}{l}0.100 \\
0.100 \\
0.173\end{array}$ & $\begin{array}{l}-1.000 \\
-1.000 \\
-1.000\end{array}$ \\
\hline 1 & 8 & 82.706 & 12.662 & 50.720 & 0.100 & -1.000 \\
\hline $\begin{array}{l}1 \\
2\end{array}$ & $\begin{array}{l}9 \\
9\end{array}$ & $\begin{array}{r}93.999 \\
100.112\end{array}$ & $\begin{array}{l}12.662 \\
12.662\end{array}$ & $\begin{array}{r}58.375 \\
104.138\end{array}$ & $\begin{array}{l}0.414 \\
0.109\end{array}$ & $\begin{array}{l}5.000 \\
5.000\end{array}$ \\
\hline $\begin{array}{l}1 \\
2\end{array}$ & $\begin{array}{l}10 \\
10\end{array}$ & $\begin{array}{l}311.812 \\
257.977\end{array}$ & $\begin{array}{l}79.771 \\
34.267\end{array}$ & $\begin{array}{l}281.933 \\
281.933\end{array}$ & $\begin{array}{l}0.455 \\
0.458\end{array}$ & $\begin{array}{l}0.000 \\
0.059\end{array}$ \\
\hline
\end{tabular}




\section{A.12}

Table A6

FLUID FLOW RATES FOR THE DOUBLE-FLASH CYCLE AT RESOURCE TEMPERATURE $=429^{\circ} \mathrm{K}\left(312^{\circ} \mathrm{F}\right)$

\begin{tabular}{rrrrr}
\hline L & \multicolumn{1}{c}{$\begin{array}{c}\text { G } \\
(\mathrm{KG} / \mathrm{SEC})\end{array}$} & \multicolumn{1}{c}{ G } \\
(KLB/HR) & $\begin{array}{l}\text { Fluid } \\
\text { Number }\end{array}$ & $\begin{array}{c}\text { Fluid } \\
\text { Description }\end{array}$ \\
\hline 1 & 46.70026 & 370.64316 & 1 & Water \\
2 & 2.91682 & 23.14974 & 1 & Water \\
3 & 43.74639 & 347.19935 & 1 & Water \\
4 & 2.95387 & 23.44382 & -1 & Water \\
5 & 5.87069 & 46.59355 & 1 & Water \\
6 & 49.61708 & 393.79290 & 1 & Water \\
7 & 133.31015 & 1058.03467 & 1 & Water \\
8 & 5.07642 & 40.28976 & 1 & Water \\
9 & 121.51386 & 964.41178 & 7 & Atmospheric Air \\
10 & 49.61708 & 393.79290 & 1 & Water \\
\hline
\end{tabular}




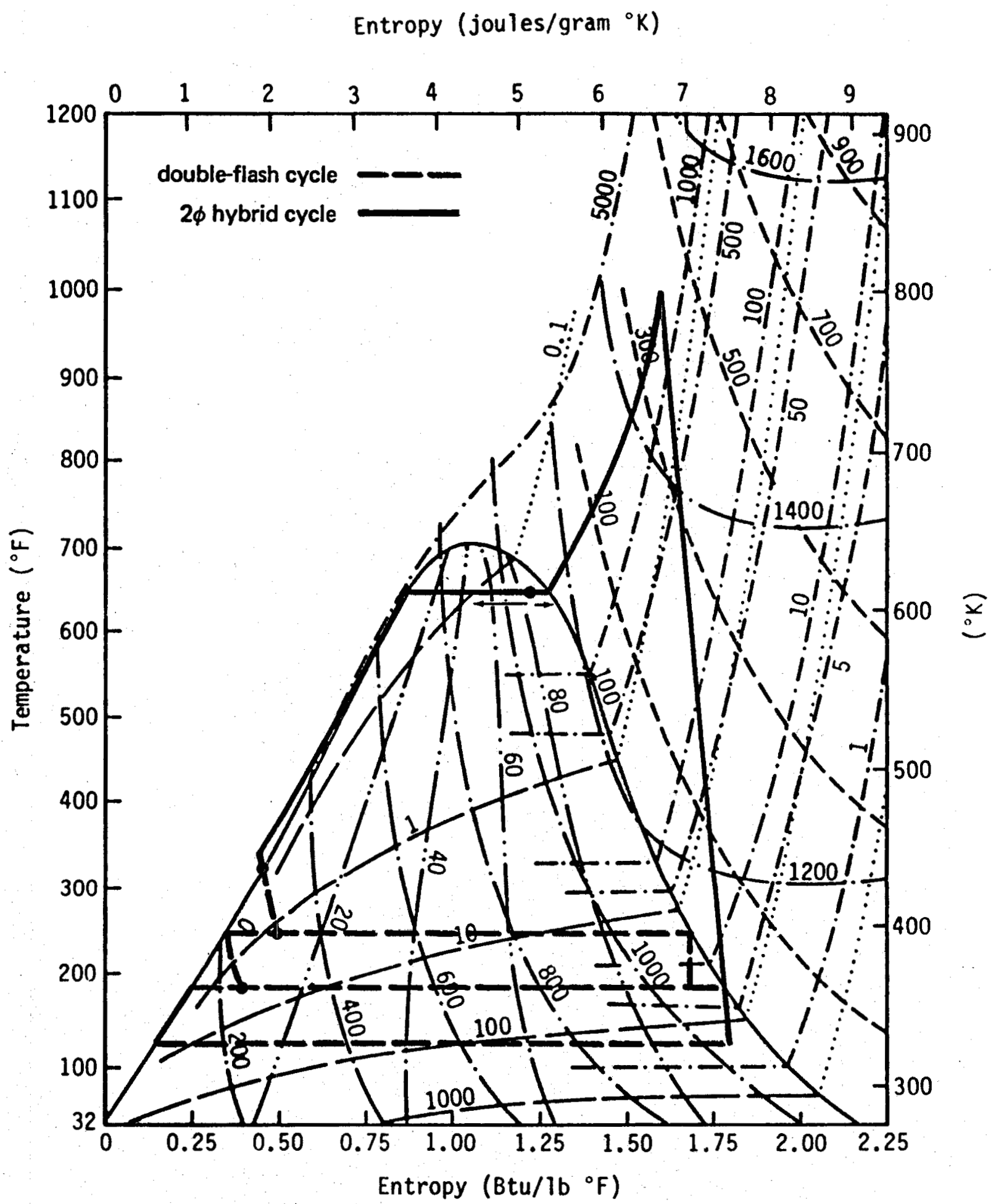

Fig. A4--Temperature-entropy diagram for the double-flash and $2 \emptyset$ hybrid cycles. Resource temperature $=429^{\circ} \mathrm{K}\left(312^{\circ} \mathrm{F}\right)$ 
Table A7

STATE POINTS FOR THE $2 \emptyset$ HYBRID CYCLE AT RESOURCE TEMPERATURE $=469^{\circ} \mathrm{K}\left(384^{\circ} \mathrm{F}\right)$

\begin{tabular}{|c|c|c|c|c|c|c|}
\hline $\mathbf{R}$ & $\mathbf{L}$ & $\stackrel{\mathrm{T}}{(\mathrm{DEG} K)}$ & $\begin{array}{c}\mathrm{P} \\
\text { (BAR) }\end{array}$ & $\underset{(J / G)}{H}$ & $\underset{(J / G K)}{S}$ & $Q$ \\
\hline $\begin{array}{l}1 \\
2\end{array}$ & $\begin{array}{l}1 \\
1\end{array}$ & $\begin{array}{l}307.604 \\
480.000\end{array}$ & $\begin{array}{l}0.873 \\
0.873\end{array}$ & $\begin{array}{r}9.476 \\
370.276\end{array}$ & $\begin{array}{l}0.070 \\
2.744\end{array}$ & $\begin{array}{r}5.000 \\
-2.000\end{array}$ \\
\hline $\begin{array}{l}1 \\
2\end{array}$ & $\begin{array}{l}2 \\
2\end{array}$ & $\begin{array}{l}307.604 \\
480.000\end{array}$ & $\begin{array}{l}0.873 \\
0.873\end{array}$ & $\begin{array}{r}9.476 \\
182.468\end{array}$ & $\begin{array}{l}0.070 \\
0.517\end{array}$ & $\begin{array}{l}5.000 \\
5.000\end{array}$ \\
\hline $\begin{array}{l}1 \\
2\end{array}$ & $\begin{array}{l}3 \\
3\end{array}$ & $\begin{array}{l}2324.444 \\
1762.017\end{array}$ & $\begin{array}{l}0.873 \\
0.873\end{array}$ & $\begin{array}{l}2595.813 \\
1875.304\end{array}$ & $\begin{array}{l}2.668 \\
2.313\end{array}$ & $\begin{array}{l}5.000 \\
5.000\end{array}$ \\
\hline $\begin{array}{l}1 \\
2 \\
3\end{array}$ & $\begin{array}{l}4 \\
4 \\
4\end{array}$ & $\begin{array}{l}325.572 \\
325.572 \\
330.049\end{array}$ & $\begin{array}{r}0.140 \\
0.140 \\
148.573\end{array}$ & $\begin{array}{r}2208.431 \\
114.564 \\
133.274\end{array}$ & $\begin{array}{l}6.798 \\
0.367 \\
0.379\end{array}$ & $\begin{array}{r}0.881 \\
0.000 \\
-1.000\end{array}$ \\
\hline $\begin{array}{l}1 \\
2\end{array}$ & $\begin{array}{l}5 \\
5\end{array}$ & $\begin{array}{l}352.965 \\
348.964\end{array}$ & $\begin{array}{r}148.573 \\
17.200\end{array}$ & $\begin{array}{l}229.239 \\
212.460\end{array}$ & $\begin{array}{l}0.662 \\
0.653\end{array}$ & $\begin{array}{l}-1.000 \\
-1.000\end{array}$ \\
\hline $\begin{array}{l}1 \\
2 \\
3 \\
4\end{array}$ & $\begin{array}{l}6 \\
6 \\
6 \\
6\end{array}$ & $\begin{array}{l}301.330 \\
301.443 \\
320.572 \\
301.330\end{array}$ & $\begin{array}{l}0.873 \\
4.700 \\
3.700 \\
0.873\end{array}$ & $\begin{array}{l}13.294 \\
13.765 \\
93.673 \\
13.294\end{array}$ & $\begin{array}{l}0.044 \\
0.044 \\
0.302 \\
0.044\end{array}$ & $\begin{array}{l}-1.000 \\
-1.000 \\
-1.000 \\
-1.000\end{array}$ \\
\hline 1 & 7 & 299.827 & 0.873 & 7.010 & 0.023 & -1.000 \\
\hline $\begin{array}{l}1 \\
2\end{array}$ & $\begin{array}{l}8 \\
8\end{array}$ & $\begin{array}{l}307.604 \\
311.000\end{array}$ & $\begin{array}{l}0.873 \\
0.873\end{array}$ & $\begin{array}{r}31.094 \\
137.512\end{array}$ & $\begin{array}{l}1.357 \\
0.081\end{array}$ & $\begin{array}{l}5.000 \\
5.000\end{array}$ \\
\hline $\begin{array}{l}1 \\
2\end{array}$ & $\begin{array}{l}9 \\
9\end{array}$ & $\begin{array}{l}492.978 \\
370.578\end{array}$ & $\begin{array}{l}0.873 \\
0.873\end{array}$ & $\begin{array}{r}249.575 \\
92.771\end{array}$ & $\begin{array}{l}0.682 \\
0.316\end{array}$ & $\begin{array}{l}5.000 \\
5.000\end{array}$ \\
\hline $\begin{array}{l}1 \\
2 \\
3\end{array}$ & $\begin{array}{l}10 \\
10 \\
10\end{array}$ & $\begin{array}{l}468.542 \\
472.848 \\
614.599\end{array}$ & $\begin{array}{r}14.100 \\
148.573 \\
148.573\end{array}$ & $\begin{array}{r}726.860 \\
746.209 \\
2436.866\end{array}$ & $\begin{array}{l}1.920 \\
1.928 \\
4.832\end{array}$ & $\begin{array}{r}0.000 \\
-1.000 \\
0.930\end{array}$ \\
\hline $\begin{array}{l}1 \\
2\end{array}$ & $\begin{array}{l}11 \\
11\end{array}$ & $\begin{array}{l}614.599 \\
614.599\end{array}$ & $\begin{array}{l}148.573 \\
148.573\end{array}$ & $\begin{array}{l}1500.022 \\
1500.022\end{array}$ & $\begin{array}{l}3.309 \\
3.309\end{array}$ & $\begin{array}{l}0.000 \\
0.000\end{array}$ \\
\hline $\begin{array}{l}1 \\
2\end{array}$ & $\begin{array}{l}12 \\
12\end{array}$ & $\begin{array}{l}810.980 \\
325.572\end{array}$ & $\begin{array}{r}148.073 \\
0.140\end{array}$ & $\begin{array}{l}3313.484 \\
2208.431\end{array}$ & $\begin{array}{l}6.121 \\
6.798\end{array}$ & $\begin{array}{l}2.000 \\
0.881\end{array}$ \\
\hline $\begin{array}{l}1 \\
2\end{array}$ & $\begin{array}{l}13 \\
13\end{array}$ & $\begin{array}{l}810.980 \\
325.572\end{array}$ & $\begin{array}{r}148.073 \\
0.140\end{array}$ & $\begin{array}{l}3313.484 \\
2208.431\end{array}$ & $\begin{array}{l}6.121 \\
6.798\end{array}$ & $\begin{array}{l}2.000 \\
0.881\end{array}$ \\
\hline 1 & 14 & 1762.017 & 0.873 & 1875.304 & 2.313 & 5.000 \\
\hline$\frac{1}{2}$ & $\begin{array}{l}15 \\
15\end{array}$ & $\begin{array}{r}1762.017 \\
492.849\end{array}$ & $\begin{array}{l}0.873 \\
0.873\end{array}$ & $\begin{array}{r}1875.304 \\
249.409\end{array}$ & $\begin{array}{l}2.313 \\
0.681\end{array}$ & $\begin{array}{l}5.000 \\
5.000\end{array}$ \\
\hline $\begin{array}{l}1 \\
2\end{array}$ & $\begin{array}{l}16 \\
16\end{array}$ & $\begin{array}{l}614.599 \\
810.980\end{array}$ & $\begin{array}{l}148.573 \\
148.073\end{array}$ & $\begin{array}{l}2507.614 \\
3313.484\end{array}$ & $\begin{array}{l}4.947 \\
6.121\end{array}$ & $\begin{array}{l}1.000 \\
2.000\end{array}$ \\
\hline
\end{tabular}


Table A8

STATE POINTS FOR THE $2 \emptyset$ HYBRID CYCLE AT RESOURCE TEMPERATURE $=384^{\circ} \mathrm{F}\left(469^{\circ} \mathrm{K}\right)$

\begin{tabular}{|c|c|c|c|c|c|c|}
\hline $\mathbf{K}$ & $\mathbf{L}$ & $\stackrel{\mathrm{T}}{(\mathrm{DEG} F)}$ & $\begin{array}{c}P \\
\text { (PSIA) }\end{array}$ & $\begin{array}{c}\mathrm{H} \\
(\mathrm{BTU} / \mathrm{LB})\end{array}$ & $\frac{\mathrm{S}}{(\mathrm{BTU} / \mathrm{F}-\mathrm{LB})}$ & $Q$ \\
\hline $\begin{array}{l}1 \\
2\end{array}$ & $\begin{array}{l}1 \\
1\end{array}$ & $\begin{array}{r}93.999 \\
404.312\end{array}$ & $\begin{array}{l}12.662 \\
12.662\end{array}$ & $\begin{array}{r}49.078 \\
204.234\end{array}$ & $\begin{array}{l}0.106 \\
0.745\end{array}$ & $\begin{array}{r}5.000 \\
-2.000\end{array}$ \\
\hline $\begin{array}{l}1 \\
2\end{array}$ & $\begin{array}{l}2 \\
2\end{array}$ & $\begin{array}{r}93.999 \\
404.312\end{array}$ & $\begin{array}{l}12.662 \\
12.662\end{array}$ & $\begin{array}{r}49.078 \\
123.471\end{array}$ & $\begin{array}{l}0.106 \\
0.213\end{array}$ & $\begin{array}{l}5.000 \\
5.000\end{array}$ \\
\hline $\begin{array}{l}1 \\
2\end{array}$ & $\begin{array}{l}3 \\
3\end{array}$ & $\begin{array}{l}3724.312 \\
2711.943\end{array}$ & $\begin{array}{l}12.662 \\
12.662\end{array}$ & $\begin{array}{r}1161.290 \\
851.447\end{array}$ & $\begin{array}{l}0.727 \\
0.642\end{array}$ & $\begin{array}{l}5.000 \\
5.000\end{array}$ \\
\hline $\begin{array}{l}1 \\
2 \\
3\end{array}$ & $\begin{array}{l}4 \\
4 \\
4\end{array}$ & $\begin{array}{l}126.342 \\
126.342 \\
134.400\end{array}$ & $\begin{array}{r}2.031 \\
2.031 \\
2154.870\end{array}$ & $\begin{array}{r}994.702 \\
94.269 \\
102.315\end{array}$ & $\begin{array}{l}1.714 \\
0.177 \\
0.180\end{array}$ & $\begin{array}{r}0.881 \\
0.000 \\
-1.000\end{array}$ \\
\hline $\begin{array}{l}1 \\
2\end{array}$ & $\begin{array}{l}5 \\
5\end{array}$ & $\begin{array}{l}175.648 \\
168.448\end{array}$ & $\begin{array}{r}2154.870 \\
249.465\end{array}$ & $\begin{array}{l}143.584 \\
136.368\end{array}$ & $\begin{array}{l}0.248 \\
0.245\end{array}$ & $\begin{array}{l}-1.000 \\
-1.000\end{array}$ \\
\hline $\begin{array}{l}1 \\
2 \\
3 \\
4\end{array}$ & $\begin{array}{l}6 \\
6 \\
6 \\
6\end{array}$ & $\begin{array}{r}82.706 \\
82.909 \\
117.342 \\
82.706\end{array}$ & $\begin{array}{l}12.662 \\
68.168 \\
53.664 \\
12.662\end{array}$ & $\begin{array}{l}50.720 \\
50.923 \\
85.286 \\
50.720\end{array}$ & $\begin{array}{l}0.100 \\
0.100 \\
0.162 \\
0.100\end{array}$ & $\begin{array}{l}-1.000 \\
-1.000 \\
-1.000 \\
-1.000\end{array}$ \\
\hline 1 & 7 & 80.001 & 12.662 & 48.018 & 0.095 & -1.000 \\
\hline$\frac{1}{2}$ & $\begin{array}{l}8 \\
8\end{array}$ & $\begin{array}{r}93.999 \\
100.112\end{array}$ & $\begin{array}{l}12.662 \\
12.662\end{array}$ & $\begin{array}{r}58.375 \\
104.138\end{array}$ & $\begin{array}{l}0.414 \\
0.109\end{array}$ & $\begin{array}{l}5.000 \\
5.000\end{array}$ \\
\hline $\begin{array}{l}1 \\
2\end{array}$ & $\begin{array}{l}9 \\
9\end{array}$ & $\begin{array}{l}427.673 \\
207.353\end{array}$ & $\begin{array}{l}12.662 \\
12.662\end{array}$ & $\begin{array}{r}152.329 \\
84.898\end{array}$ & $\begin{array}{l}0.252 \\
0.165\end{array}$ & $\begin{array}{l}5.000 \\
5.000\end{array}$ \\
\hline $\begin{array}{l}1 \\
2 \\
3\end{array}$ & $\begin{array}{l}10 \\
10 \\
10\end{array}$ & $\begin{array}{l}383.688 \\
391.438 \\
646.591\end{array}$ & $\begin{array}{r}204.504 \\
2154.870 \\
2154.870\end{array}$ & $\begin{array}{r}357.577 \\
365.898 \\
1092.937\end{array}$ & $\begin{array}{l}0.548 \\
0.550 \\
1.244\end{array}$ & $\begin{array}{r}0.000 \\
-1.000 \\
0.930\end{array}$ \\
\hline $\begin{array}{l}1 \\
2\end{array}$ & $\begin{array}{l}11 \\
11\end{array}$ & $\begin{array}{l}646.591 \\
646.591\end{array}$ & $\begin{array}{l}2154.870 \\
2154.870\end{array}$ & $\begin{array}{l}690.063 \\
690.063\end{array}$ & $\begin{array}{l}0.880 \\
0.880\end{array}$ & $\begin{array}{l}0.000 \\
0.000\end{array}$ \\
\hline $\begin{array}{l}1 \\
2\end{array}$ & $\begin{array}{l}12 \\
12\end{array}$ & $\begin{array}{r}1000.076 \\
126.342\end{array}$ & $\begin{array}{r}2147.618 \\
2.031\end{array}$ & $\begin{array}{r}1469.912 \\
994.702\end{array}$ & $\begin{array}{l}1.552 \\
1.714\end{array}$ & $\begin{array}{l}2.000 \\
0.881\end{array}$ \\
\hline $\begin{array}{l}1 \\
2\end{array}$ & $\begin{array}{l}13 \\
13\end{array}$ & $\begin{array}{r}1000.076 \\
126.342\end{array}$ & $\begin{array}{r}2147.618 \\
2.031\end{array}$ & $\begin{array}{r}1469.912 \\
994.702\end{array}$ & $\begin{array}{l}1.552 \\
1.714\end{array}$ & $\begin{array}{l}2.000 \\
0.881\end{array}$ \\
\hline 1 & 14 & 2711.943 & 12.662 & 851.447 & 0.642 & 5.000 \\
\hline $\begin{array}{l}1 \\
2\end{array}$ & $\begin{array}{l}15 \\
15\end{array}$ & $\begin{array}{r}2711.943 \\
427.440\end{array}$ & $\begin{array}{l}12.662 \\
12.662\end{array}$ & $\begin{array}{l}851.447 \\
152.257\end{array}$ & $\begin{array}{l}0.642 \\
0.252\end{array}$ & $\begin{array}{l}5.000 \\
5.000\end{array}$ \\
\hline $\begin{array}{l}1 \\
2\end{array}$ & $\begin{array}{l}16 \\
16\end{array}$ & $\begin{array}{r}646.591 \\
1000.076\end{array}$ & $\begin{array}{l}2154.870 \\
2147.618\end{array}$ & $\begin{array}{l}1123.361 \\
1469.912\end{array}$ & $\begin{array}{l}1.271 \\
1.552\end{array}$ & $\begin{array}{l}1.000 \\
2.000\end{array}$ \\
\hline
\end{tabular}




\section{A. 16}

Table A9

STREAM FLOW RATES FOR THE 20 HYBRID CYCLE AT RESOURCE TEMPERATURE $=469^{\circ} \mathrm{K}\left(384^{\circ} \mathrm{F}\right)$

\begin{tabular}{rrrrr}
\hline L & \multicolumn{1}{c}{$\begin{array}{c}\text { G } \\
\text { (KG/SEC) }\end{array}$} & $\begin{array}{c}\text { G } \\
\text { (KLB/HR) }\end{array}$ & $\begin{array}{c}\text { Fluld } \\
\text { Number }\end{array}$ & $\begin{array}{c}\text { Fluid } \\
\text { Description }\end{array}$ \\
\hline 1 & 5.03992 & 40.00000 & 7 & Coal \\
2 & 48.81438 & 387.42217 & 7 & Atmospheric Air \\
3 & 53.85430 & 427.42217 & 6 & Flue Gases \\
4 & 48.14991 & 382.14852 & 1 & Water \\
5 & 51.78608 & 411.00744 & 1 & Water \\
6 & 1261.69746 & 10013.63856 & 1 & Water \\
7 & 39.96463 & 317.18488 & 1 & Water \\
8 & 956.62926 & 7592.42203 & 7 & Atmospheric Air \\
9 & 53.85430 & 427.42217 & 6 & Flue Gases \\
10 & 51.78608 & 411.00744 & 1 & Water \\
11 & 3.63616 & 28.85892 & 1 & Water \\
12 & 24.07496 & 191.07426 & 1 & Water \\
13 & 24.07496 & 191.07426 & 1 & Water \\
14 & 0.00550 & 0.04367 & 6 & Flue Gases \\
15 & 53.84879 & 427.37850 & 6 & Flue Gases \\
16 & 48.14991 & 382.14852 & 1 & Water \\
\hline & & & &
\end{tabular}


Table Alo

STATE POINTS FOR THE DOUBLE-FLASH CYCLE AT RESOURCE TEMPERATURE $=469^{\circ} \mathrm{K}\left(384^{\circ} \mathrm{F}\right)$

\begin{tabular}{|c|c|c|c|c|c|c|}
\hline $\mathbf{K}$ & L & $\begin{array}{c}\mathrm{T} \\
(\mathrm{DEG} K)\end{array}$ & $\underset{\text { (BAR) }}{P}$ & $\begin{array}{c}H \\
(J / G)\end{array}$ & $\begin{array}{c}S \\
(J / G K)\end{array}$ & $\mathbf{Q}$ \\
\hline $\begin{array}{l}1 \\
2\end{array}$ & $\begin{array}{l}1 \\
1\end{array}$ & $\begin{array}{l}410.872 \\
369.377\end{array}$ & $\begin{array}{l}3.393 \\
0.887\end{array}$ & $\begin{array}{l}474.477 \\
474.477\end{array}$ & $\begin{array}{l}1.348 \\
1.374\end{array}$ & $\begin{array}{l}0.000 \\
0.078\end{array}$ \\
\hline $\begin{array}{l}1 \\
2\end{array}$ & $\begin{array}{l}2 \\
2\end{array}$ & $\begin{array}{l}410.872 \\
369.377\end{array}$ & $\begin{array}{l}3.393 \\
0.887\end{array}$ & $\begin{array}{l}2624.696 \\
2432.851\end{array}$ & $\begin{array}{l}6.581 \\
6.675\end{array}$ & $\begin{array}{l}1.000 \\
0.942\end{array}$ \\
\hline 1 & 3 & 369.377 & 0.887 & 298.251 & 0.897 & 0.000 \\
\hline 1 & 4 & 369.377 & 0.887 & 2564.556 & 7.032 & 1,000 \\
\hline $\begin{array}{l}1 \\
2 \\
3 \\
4\end{array}$ & $\begin{array}{l}5 \\
5 \\
5 \\
5\end{array}$ & $\begin{array}{l}369.377 \\
325.572 \\
325.572 \\
325.595\end{array}$ & $\begin{array}{l}0.887 \\
0.140 \\
0.140 \\
0.887\end{array}$ & $\begin{array}{r}2481.447 \\
2254.464 \\
114.564 \\
114.656\end{array}$ & $\begin{array}{l}6.807 \\
6.940 \\
0.367 \\
0.367\end{array}$ & $\begin{array}{r}0.963 \\
0.900 \\
0.000 \\
-1.000\end{array}$ \\
\hline $\begin{array}{l}1 \\
2\end{array}$ & $\begin{array}{l}6 \\
6\end{array}$ & $\begin{array}{l}361.264 \\
361.772\end{array}$ & $\begin{array}{r}0.887 \\
17.500\end{array}$ & $\begin{array}{l}264.100 \\
266.237\end{array}$ & $\begin{array}{l}0.803 \\
0.804\end{array}$ & $\begin{array}{l}-1.000 \\
-1.000\end{array}$ \\
\hline $\begin{array}{l}1 \\
2 \\
3\end{array}$ & $\begin{array}{l}7 \\
7 \\
7\end{array}$ & $\begin{array}{l}301.330 \\
301.443 \\
324.405\end{array}$ & $\begin{array}{l}0.873 \\
4.700 \\
3.700\end{array}$ & $\begin{array}{r}13.294 \\
13.765 \\
109.686\end{array}$ & $\begin{array}{l}0.044 \\
0.044 \\
0.351\end{array}$ & $\begin{array}{l}-1.000 \\
-1.000 \\
-1.000\end{array}$ \\
\hline 1 & 8 & 301.330 & 0.873 & 13.294 & 0.044 & -1.000 \\
\hline $\begin{array}{l}1 \\
2\end{array}$ & $\begin{array}{l}9 \\
9\end{array}$ & $\begin{array}{l}307.604 \\
311.000\end{array}$ & $\begin{array}{l}0.873 \\
0.873\end{array}$ & $\begin{array}{r}31.094 \\
137.512\end{array}$ & $\begin{array}{l}1.357 \\
0.081\end{array}$ & $\begin{array}{l}5.000 \\
5.000\end{array}$ \\
\hline $\begin{array}{l}1 \\
2\end{array}$ & $\begin{array}{l}10 \\
10\end{array}$ & $\begin{array}{l}468.542 \\
410.872\end{array}$ & $\begin{array}{r}14.100 \\
3.393\end{array}$ & $\begin{array}{l}726.860 \\
726.860\end{array}$ & $\begin{array}{l}1.920 \\
1.962\end{array}$ & $\begin{array}{l}0.000 \\
0.117\end{array}$ \\
\hline
\end{tabular}




\section{A. 18}

Table All

STATE POINTS FOR THE DOUBLE-FLASH CYCLE AT RESOURCE TEMPERATURE $=384^{\circ} \mathrm{F}\left(469^{\circ} \mathrm{K}\right)$

\begin{tabular}{|c|c|c|c|c|c|c|}
\hline $\mathbf{K}$ & L & $\begin{array}{c}\mathrm{T} \\
\text { (DEG F) }\end{array}$ & $\begin{array}{c}P \\
\text { (PSIA) }\end{array}$ & $\frac{H}{(B T U / L B)}$ & $\begin{array}{c}S \\
(\mathrm{BTU} / \mathrm{F}-\mathrm{LB})\end{array}$ & $Q$ \\
\hline $\begin{array}{l}1 \\
2\end{array}$ & $\begin{array}{l}1 \\
1\end{array}$ & $\begin{array}{l}279.881 \\
205.191\end{array}$ & $\begin{array}{l}49.207 \\
12.861\end{array}$ & $\begin{array}{l}249.044 \\
249.044\end{array}$ & $\begin{array}{l}0.411 \\
0.418\end{array}$ & $\begin{array}{l}0.000 \\
0.078\end{array}$ \\
\hline$\frac{1}{2}$ & $\begin{array}{l}2 \\
2\end{array}$ & $\begin{array}{l}279.881 \\
205.191\end{array}$ & $\begin{array}{l}49.207 \\
12.861\end{array}$ & $\begin{array}{l}1173.710 \\
1091.211\end{array}$ & $\begin{array}{l}1.662 \\
1.684\end{array}$ & $\begin{array}{l}1.000 \\
0.942\end{array}$ \\
\hline 1 & 3 & 205.191 & 12.861 & 173.261 & 0.304 & 0.000 \\
\hline 1 & 4 & 205.191 & 12.861 & 1147.848 & 1.769 & 1.000 \\
\hline $\begin{array}{l}1 \\
2 \\
3 \\
4\end{array}$ & $\begin{array}{l}5 \\
5 \\
5 \\
5\end{array}$ & $\begin{array}{l}205.191 \\
126.342 \\
126.342 \\
126.382\end{array}$ & $\begin{array}{r}12.861 \\
2.031 \\
2.031 \\
12.861\end{array}$ & $\begin{array}{r}1112.108 \\
1014.498 \\
94.269 \\
94.309\end{array}$ & $\begin{array}{l}1.716 \\
1.747 \\
0.177 \\
0.177\end{array}$ & $\begin{array}{r}0.963 \\
0.900 \\
0.000 \\
-1.000\end{array}$ \\
\hline $\begin{array}{l}1 \\
2\end{array}$ & $\begin{array}{l}6 \\
6\end{array}$ & $\begin{array}{l}190.586 \\
191.502\end{array}$ & $\begin{array}{r}12.861 \\
253.817\end{array}$ & $\begin{array}{l}158.575 \\
159.494\end{array}$ & $\begin{array}{l}0.281 \\
0.282\end{array}$ & $\begin{array}{l}-1.000 \\
-1.000\end{array}$ \\
\hline $\begin{array}{l}1 \\
2 \\
3\end{array}$ & $\begin{array}{l}7 \\
7 \\
7\end{array}$ & $\begin{array}{r}82.706 \\
82.909 \\
124.241\end{array}$ & $\begin{array}{l}12.662 \\
68.168 \\
53.664\end{array}$ & $\begin{array}{l}50.720 \\
50.923 \\
92.172\end{array}$ & $\begin{array}{l}0.100 \\
0.100 \\
0.173\end{array}$ & $\begin{array}{l}-1.000 \\
-1.000 \\
-1.000\end{array}$ \\
\hline 1 & 8 & 82.706 & 12.662 & 50.720 & 0.100 & -1.000 \\
\hline $\begin{array}{l}1 \\
2\end{array}$ & $\begin{array}{l}9 \\
9\end{array}$ & $\begin{array}{r}93.999 \\
100.112\end{array}$ & $\begin{array}{l}12.662 \\
12.662\end{array}$ & $\begin{array}{r}58.375 \\
104.138\end{array}$ & $\begin{array}{l}0.414 \\
0.109\end{array}$ & $\begin{array}{l}5.000 \\
5.000\end{array}$ \\
\hline $\begin{array}{l}1 \\
2\end{array}$ & $\begin{array}{l}10 \\
10\end{array}$ & $\begin{array}{l}383.688 \\
279.881\end{array}$ & $\begin{array}{r}204.504 \\
49.207\end{array}$ & $\begin{array}{l}357.577 \\
357.577\end{array}$ & $\begin{array}{l}0.548 \\
0.558\end{array}$ & $\begin{array}{l}0.000 \\
0.117\end{array}$ \\
\hline
\end{tabular}




\section{A. 19}

Table Al2

FLUID FLOW RATES FOR THE DOUBLE-FLASH CYCLE AT RESOURCE TEMPERATURE $=469^{\circ} \mathrm{K}\left(384^{\circ} \mathrm{F}\right)$

\begin{tabular}{|c|c|c|c|c|}
\hline $\mathbf{L}$ & $\begin{array}{c}G \\
(K G / S E C)\end{array}$ & $\begin{array}{c}G \\
(\mathrm{KLB} / \mathrm{HR})\end{array}$ & $\begin{array}{l}\text { Fluid } \\
\text { Number }\end{array}$ & $\begin{array}{c}\text { Fluid } \\
\text { Description }\end{array}$ \\
\hline 1 & 45.70765 & 362.76520 & 1 & Water \\
\hline 2 & 6.07843 & 48.24228 & 1 & Water \\
\hline 3 & 42.15347 & 334.55692 & 1 & Water \\
\hline 4 & 3.55418 & 28.20828 & 1 & Water \\
\hline 5 & 9.63261 & 76.45055 & 1 & Water \\
\hline 6 & 51.78608 & 411.00747 & 1 & Water \\
\hline 7 & 214.89445 & 1705.53989 & 1 & Water \\
\hline 8 & 8.18314 & 64.94663 & 1 & Water \\
\hline 9 & 195.87897 & 1554.62086 & 7 & Atmospheric Air \\
\hline 10 & 51.78608 & 411.00747 & 1 & Water \\
\hline
\end{tabular}




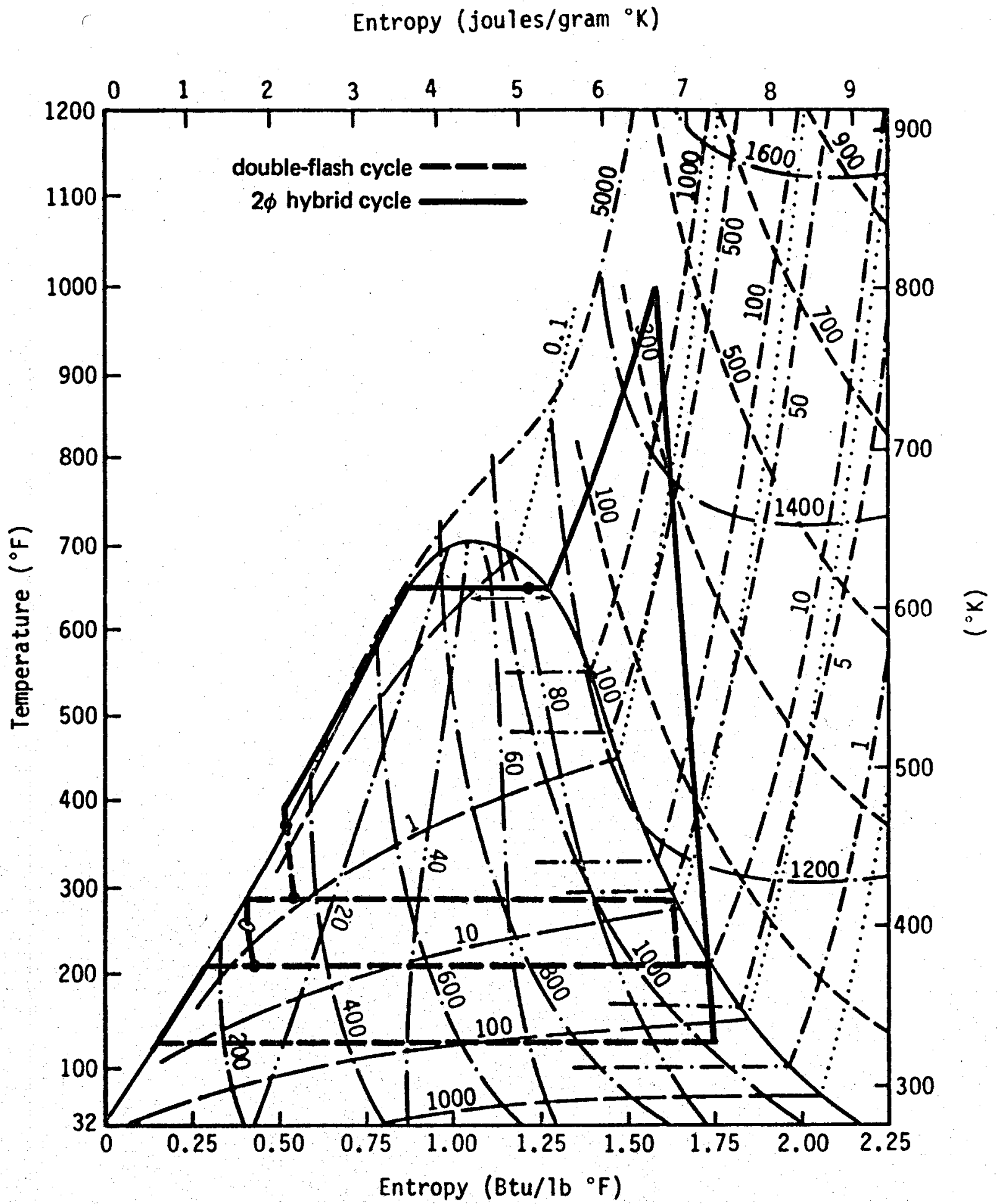

Fig. A5--Temperature-entropy diagram for the double-flash and $2 \emptyset$ hybrid cycles. Resource temperature $=469^{\circ} \mathrm{K}\left(384^{\circ} \mathrm{F}\right)$ 
Table Al3

STATE POINTS FOR THE $2 \emptyset$ HYBRID CYCLE AT RESOURCE TEMPERATURE $=550^{\circ} \mathrm{K}\left(530^{\circ} \mathrm{F}\right)$

\begin{tabular}{|c|c|c|c|c|c|c|}
\hline $\mathrm{K}$ & L & $\stackrel{\mathrm{T}}{(\mathrm{DEG} K)}$ & $\underset{(B A R)}{P}$ & $\begin{array}{c}\mathrm{H} \\
(\mathrm{J} / \mathrm{G})\end{array}$ & $\begin{array}{c}S \\
(\mathrm{~J} / \mathrm{GK})\end{array}$ & $Q$ \\
\hline $\begin{array}{l}1 \\
2\end{array}$ & $\begin{array}{l}1 \\
1\end{array}$ & $\begin{array}{l}307.604 \\
480.000\end{array}$ & $\begin{array}{l}0.873 \\
0.873\end{array}$ & $\begin{array}{r}9.476 \\
370.276\end{array}$ & $\begin{array}{l}0.070 \\
2.744\end{array}$ & $\begin{array}{r}5.000 \\
-2.000\end{array}$ \\
\hline $\begin{array}{l}1 \\
2\end{array}$ & $\begin{array}{l}2 \\
2\end{array}$ & $\begin{array}{l}307.604 \\
480.000\end{array}$ & $\begin{array}{l}0.873 \\
0.873\end{array}$ & $\begin{array}{r}9.476 \\
182.468\end{array}$ & $\begin{array}{l}0.070 \\
0.517\end{array}$ & $\begin{array}{l}5.000 \\
5.000\end{array}$ \\
\hline $\begin{array}{l}1 \\
2\end{array}$ & $\begin{array}{l}3 \\
3\end{array}$ & $\begin{array}{l}2324.444 \\
1681.683\end{array}$ & $\begin{array}{l}0.873 \\
0.873\end{array}$ & $\begin{array}{l}2595.813 \\
1772.390\end{array}$ & $\begin{array}{l}2.668 \\
2.254\end{array}$ & $\begin{array}{l}5.000 \\
5.000\end{array}$ \\
\hline $\begin{array}{l}1 \\
2 \\
3\end{array}$ & $\begin{array}{l}4 \\
4 \\
4\end{array}$ & $\begin{array}{l}325.572 \\
325.572 \\
330.068\end{array}$ & $\begin{array}{r}0.140 \\
0.140 \\
149.201\end{array}$ & $\begin{array}{r}2206.547 \\
114.564 \\
133.356\end{array}$ & $\begin{array}{l}6.793 \\
0.367 \\
0.379\end{array}$ & $\begin{array}{r}0.880 \\
0.000 \\
-1.000\end{array}$ \\
\hline $\begin{array}{l}1 \\
2\end{array}$ & $\begin{array}{l}5 \\
5\end{array}$ & $\begin{array}{l}352.611 \\
350.023\end{array}$ & $\begin{array}{r}149.201 \\
64.100\end{array}$ & $\begin{array}{l}227.755 \\
216.900\end{array}$ & $\begin{array}{l}0.658 \\
0.652\end{array}$ & $\begin{array}{l}-1.000 \\
-1.000\end{array}$ \\
\hline $\begin{array}{l}1 \\
2 \\
3 \\
4\end{array}$ & $\begin{array}{l}6 \\
6 \\
6 \\
6\end{array}$ & $\begin{array}{l}301.330 \\
301.443 \\
320.572 \\
301.330\end{array}$ & $\begin{array}{l}0.873 \\
4.700 \\
3.700 \\
0.873\end{array}$ & $\begin{array}{l}13.294 \\
13.765 \\
93.673 \\
13.294\end{array}$ & $\begin{array}{l}0.044 \\
0.044 \\
0.302 \\
0.044\end{array}$ & $\begin{array}{l}-1.000 \\
-1.000 \\
-1.000 \\
-1.000\end{array}$ \\
\hline 1 & 7 & 299.827 & 0.873 & 7.010 & 0.023 & -1.000 \\
\hline $\begin{array}{l}1 \\
2\end{array}$ & $\begin{array}{l}8 \\
8\end{array}$ & $\begin{array}{l}307.604 \\
311.000\end{array}$ & $\begin{array}{l}0.873 \\
0.873\end{array}$ & $\begin{array}{r}31.094 \\
137.512\end{array}$ & $\begin{array}{l}1.357 \\
0.081\end{array}$ & $\begin{array}{l}5.000 \\
5.000\end{array}$ \\
\hline $\begin{array}{l}1 \\
2\end{array}$ & $\begin{array}{l}9 \\
9\end{array}$ & $\begin{array}{l}558.674 \\
436.274\end{array}$ & $\begin{array}{l}0.873 \\
0.873\end{array}$ & $\begin{array}{l}333.736 \\
176.932\end{array}$ & $\begin{array}{l}0.842 \\
0.525\end{array}$ & $\begin{array}{l}5.000 \\
5.000\end{array}$ \\
\hline $\begin{array}{l}1 \\
2 \\
3\end{array}$ & $\begin{array}{l}10 \\
10 \\
10\end{array}$ & $\begin{array}{l}549.837 \\
552.656 \\
614.934\end{array}$ & $\begin{array}{r}61.000 \\
149.201 \\
149.201\end{array}$ & $\begin{array}{l}1113.933 \\
1128.546 \\
2436.697\end{array}$ & $\begin{array}{l}2.669 \\
2.674 \\
4.831\end{array}$ & $\begin{array}{r}0.000 \\
-1.000 \\
0.931\end{array}$ \\
\hline $\begin{array}{l}1 \\
2\end{array}$ & $\begin{array}{l}11 \\
11\end{array}$ & $\begin{array}{l}614.934 \\
614.934\end{array}$ & $\begin{array}{l}149.201 \\
149.201\end{array}$ & $\begin{array}{l}1502.499 \\
1502.499\end{array}$ & $\begin{array}{l}3.312 \\
3.312\end{array}$ & $\begin{array}{l}0.000 \\
0.000\end{array}$ \\
\hline $\begin{array}{l}1 \\
2\end{array}$ & $\begin{array}{l}12 \\
12\end{array}$ & $\begin{array}{l}809.957 \\
325.572\end{array}$ & $\begin{array}{r}148.701 \\
0.140\end{array}$ & $\begin{array}{l}3310.054 \\
2206.547\end{array}$ & $\begin{array}{l}6.115 \\
6.793\end{array}$ & $\begin{array}{l}2.000 \\
0.880\end{array}$ \\
\hline $\begin{array}{l}1 \\
2\end{array}$ & $\begin{array}{l}13 \\
13\end{array}$ & $\begin{array}{l}809.957 \\
325.572\end{array}$ & $\begin{array}{r}148.701 \\
0.140\end{array}$ & $\begin{array}{l}3310.054 \\
2206.547\end{array}$ & $\begin{array}{l}6.115 \\
6.793\end{array}$ & $\begin{array}{l}2.000 \\
0.880\end{array}$ \\
\hline 1 & 14 & 1681.683 & 0.873 & 1772.390 & 2.254 & 5.000 \\
\hline $\begin{array}{l}1 \\
2\end{array}$ & $\begin{array}{l}15 \\
15\end{array}$ & $\begin{array}{r}1681.683 \\
558.407\end{array}$ & $\begin{array}{l}0.873 \\
0.873\end{array}$ & $\begin{array}{r}1772.390 \\
333.394\end{array}$ & $\begin{array}{l}2.254 \\
0.841\end{array}$ & $\begin{array}{l}5.000 \\
5.000\end{array}$ \\
\hline $\begin{array}{l}1 \\
2\end{array}$ & $\begin{array}{l}16 \\
16\end{array}$ & $\begin{array}{l}614.934 \\
809.957\end{array}$ & $\begin{array}{l}149.201 \\
148.701\end{array}$ & $\begin{array}{l}2505.878 \\
3310.054\end{array}$ & $\begin{array}{l}4.944 \\
6.115\end{array}$ & $\begin{array}{l}1.000 \\
2.000\end{array}$ \\
\hline
\end{tabular}


Table Al4

STATE POINTS FOR THE $2 \emptyset$ HYBRID CYCLE AT RESOURCE TEMPERATURE $=530^{\circ} \mathrm{F}\left(550^{\circ} \mathrm{K}\right)$

\begin{tabular}{|c|c|c|c|c|c|c|}
\hline $\mathbf{K}$ & L & $\stackrel{\text { T }}{\text { (DEG F) }}$ & $\begin{array}{c}P \\
\text { (PSIA) }\end{array}$ & $\begin{array}{c}\mathrm{H} \\
(\mathrm{BTU} / \mathrm{LB})\end{array}$ & $\frac{\mathrm{S}}{(\mathrm{BTU} / \mathrm{F}-\mathrm{LB})}$ & $Q$ \\
\hline $\begin{array}{l}1 \\
2\end{array}$ & $\begin{array}{l}1 \\
1\end{array}$ & $\begin{array}{r}93.999 \\
404.312\end{array}$ & $\begin{array}{l}12.662 \\
12.662\end{array}$ & $\begin{array}{r}49.078 \\
204.234\end{array}$ & $\begin{array}{l}0.106 \\
0.745\end{array}$ & $\begin{array}{r}5.000 \\
-2.000\end{array}$ \\
\hline $\begin{array}{l}1 \\
2\end{array}$ & $\begin{array}{l}2 \\
2\end{array}$ & $\begin{array}{r}93.999 \\
404.312\end{array}$ & $\begin{array}{l}12.662 \\
12.662\end{array}$ & $\begin{array}{r}49.078 \\
123.471\end{array}$ & $\begin{array}{l}0.106 \\
0.213\end{array}$ & $\begin{array}{l}5.000 \\
5.000\end{array}$ \\
\hline $\begin{array}{l}1 \\
2\end{array}$ & $\begin{array}{l}3 \\
3\end{array}$ & $\begin{array}{l}3724.312 \\
2567.341\end{array}$ & $\begin{array}{l}12.662 \\
12.662\end{array}$ & $\begin{array}{r}1161.290 \\
807.190\end{array}$ & $\begin{array}{l}0.727 \\
0.628\end{array}$ & $\begin{array}{l}5.000 \\
5.000\end{array}$ \\
\hline $\begin{array}{l}1 \\
2 \\
3\end{array}$ & $\begin{array}{l}4 \\
4 \\
4\end{array}$ & $\begin{array}{l}126.342 \\
126.342 \\
134.435\end{array}$ & $\begin{array}{r}2.031 \\
2.031 \\
2163.983\end{array}$ & $\begin{array}{r}993.892 \\
94.269 \\
102.350\end{array}$ & $\begin{array}{l}1.712 \\
0.177 \\
0.180\end{array}$ & $\begin{array}{r}0.880 \\
0.000 \\
-1.000\end{array}$ \\
\hline $\begin{array}{l}1 \\
2\end{array}$ & $\begin{array}{l}5 \\
5\end{array}$ & $\begin{array}{l}175.011 \\
170.353\end{array}$ & $\begin{array}{r}2163.983 \\
929.694\end{array}$ & $\begin{array}{l}142.945 \\
138.277\end{array}$ & $\begin{array}{l}0.247 \\
0.245\end{array}$ & $\begin{array}{l}-1.000 \\
-1.000\end{array}$ \\
\hline $\begin{array}{l}1 \\
2 \\
3 \\
4\end{array}$ & $\begin{array}{l}6 \\
6 \\
6 \\
6\end{array}$ & $\begin{array}{r}82.706 \\
82.909 \\
117.342 \\
82.706\end{array}$ & $\begin{array}{l}12.662 \\
68.168 \\
53.664 \\
12.662\end{array}$ & $\begin{array}{l}50.720 \\
50.923 \\
85.286 \\
50.720\end{array}$ & $\begin{array}{l}0.100 \\
0.100 \\
0.162 \\
0.100\end{array}$ & $\begin{array}{l}-1.000 \\
-1.000 \\
-1.000 \\
-1.000\end{array}$ \\
\hline 1 & 7 & 80.001 & 12.662 & 48.018 & 0.095 & -1.000 \\
\hline $\begin{array}{l}1 \\
2\end{array}$ & $\begin{array}{l}8 \\
8\end{array}$ & $\begin{array}{r}93.999 \\
100.112\end{array}$ & $\begin{array}{l}12.662 \\
12.662\end{array}$ & $\begin{array}{r}58.375 \\
104.138\end{array}$ & $\begin{array}{l}0.414 \\
0.109\end{array}$ & $\begin{array}{l}5.000 \\
5.000\end{array}$ \\
\hline $\begin{array}{l}1 \\
2\end{array}$ & $\begin{array}{l}9 \\
9\end{array}$ & $\begin{array}{l}545.925 \\
325.605\end{array}$ & $\begin{array}{l}12.662 \\
12.662\end{array}$ & $\begin{array}{l}188.520 \\
121.090\end{array}$ & $\begin{array}{l}0.291 \\
0.215\end{array}$ & $\begin{array}{l}5.000 \\
5.000\end{array}$ \\
\hline $\begin{array}{l}1 \\
2 \\
3\end{array}$ & $\begin{array}{l}10 \\
10 \\
10\end{array}$ & $\begin{array}{l}530.019 \\
535.093 \\
647.193\end{array}$ & $\begin{array}{r}884.732 \\
2163.983 \\
2163.983\end{array}$ & $\begin{array}{r}524.032 \\
530.315 \\
1092.865\end{array}$ & $\begin{array}{l}0.727 \\
0.728 \\
1.244\end{array}$ & $\begin{array}{r}0.000 \\
-1.000 \\
0.931\end{array}$ \\
\hline $\begin{array}{l}1 \\
2\end{array}$ & $\begin{array}{l}11 \\
11\end{array}$ & $\begin{array}{l}647.193 \\
647.193\end{array}$ & $\begin{array}{l}2163.983 \\
2163.983\end{array}$ & $\begin{array}{l}691.128 \\
691.128\end{array}$ & $\begin{array}{l}0.881 \\
0.881\end{array}$ & $\begin{array}{l}0.000 \\
0.000\end{array}$ \\
\hline $\begin{array}{l}1 \\
2\end{array}$ & $\begin{array}{l}12 \\
12\end{array}$ & $\begin{array}{l}998.235 \\
126.342\end{array}$ & $\begin{array}{r}2156.731 \\
2.031\end{array}$ & $\begin{array}{r}1468.437 \\
993.892\end{array}$ & $\begin{array}{l}1.550 \\
1.712\end{array}$ & $\begin{array}{l}2.000 \\
0.880\end{array}$ \\
\hline $\begin{array}{l}1 \\
2\end{array}$ & $\begin{array}{l}13 \\
13\end{array}$ & $\begin{array}{l}998.235 \\
126.342\end{array}$ & $\begin{array}{r}2156.731 \\
2.031\end{array}$ & $\begin{array}{r}1468.437 \\
993.892\end{array}$ & $\begin{array}{l}1.550 \\
1.71 .2\end{array}$ & $\begin{array}{l}2.000 \\
0.880\end{array}$ \\
\hline 1 & 14 & 2567.341 & 12.662 & 807.190 & 0.628 & 5.000 \\
\hline $\begin{array}{l}1 \\
2\end{array}$ & $\begin{array}{l}15 \\
15\end{array}$ & $\begin{array}{r}2567.341 \\
545.445\end{array}$ & $\begin{array}{l}12.662 \\
12.662\end{array}$ & $\begin{array}{l}807.190 \\
188.373\end{array}$ & $\begin{array}{l}0.628 \\
0.290\end{array}$ & $\begin{array}{l}5.000 \\
5.000\end{array}$ \\
\hline $\begin{array}{l}1 \\
2\end{array}$ & $\begin{array}{l}16 \\
16\end{array}$ & $\begin{array}{l}647.193 \\
998.235\end{array}$ & $\begin{array}{l}2163.983 \\
2156.731\end{array}$ & $\begin{array}{l}1122.615 \\
1468.437\end{array}$ & $\begin{array}{l}1.270 \\
1.550\end{array}$ & $\begin{array}{l}1.000 \\
2.000\end{array}$ \\
\hline
\end{tabular}




\section{A. 23}

Table A15

STREAM FLOW RATES FOR THE $2 \emptyset$ HYBRID CYCLE AT RESOURCE TEMPERATURE $=550^{\circ} \mathrm{K}\left(530^{\circ} \mathrm{F}\right)$

\begin{tabular}{|c|c|c|c|c|}
\hline L & $\begin{array}{c}\mathrm{G} \\
(\mathrm{KG} / \mathrm{SEC})\end{array}$ & $\begin{array}{c}\mathrm{G} \\
(\mathrm{KLB} / \mathrm{HR})\end{array}$ & $\begin{array}{l}\text { Fluid } \\
\text { Number }\end{array}$ & $\begin{array}{c}\text { Fluid } \\
\text { Description }\end{array}$ \\
\hline 1 & 5.03992 & 40.00000 & 7 & Coal \\
\hline 2 & 48.81438 & 387.42217 & 7 & Atmospheric Air \\
\hline 3 & 53.85430 & 427.42217 & 6 & Flue Gases \\
\hline 4 & 55.14328 & 437.65233 & 1 & Water \\
\hline 5 & 59.22686 & 470.06228 & 1 & Water \\
\hline 6 & 1443.64820 & 11457.71608 & 1 & Water \\
\hline 7 & 45.72797 & 362.92645 & 1 & Water \\
\hline 8 & 1094.58578 & 8687.33332 & 7 & Atmospheric Air \\
\hline 9 & 53.85430 & 427.42217 & 6 & Flue Gases \\
\hline 10 & 59.22686 & 470.06228 & 1 & Water \\
\hline 11 & 4.08359 & 32.40995 & 1 & Water \\
\hline 12 . & 27.57164 & 218.82617 & 1 & Water \\
\hline 13 & 27.57164 & 218.82617 & 1 & Water \\
\hline 14 & 0.01279 & 0.10153 & 6 & Flue Gases \\
\hline 15 & 53.84150 & 427.32063 & 6 & Flue Gases \\
\hline 16 & 55.14328 & 437.65233 & 1 & Water \\
\hline
\end{tabular}


Table Al6

STATE POINTS FOR THE DOUBLE-FLASH CYCLE AT RESOURCE TEMPERATURE $=550^{\circ} \mathrm{K}\left(530^{\circ} \mathrm{F}\right)$

\begin{tabular}{|c|c|c|c|c|c|c|}
\hline $\mathbf{K}$ & $\mathbf{L}$ & $\stackrel{\text { T }}{\text { (DEG K) }}$ & $\underset{(B A R)}{P}$ & $\underset{(J / G)}{H}$ & $\begin{array}{c}S \\
(J / G K)\end{array}$ & $Q$ \\
\hline $\begin{array}{l}1 \\
2\end{array}$ & $\begin{array}{l}1 \\
1\end{array}$ & $\begin{array}{l}478.869 \\
403.171\end{array}$ & $\begin{array}{r}17.493 \\
2.703\end{array}$ & $\begin{array}{l}773.429 \\
773.429\end{array}$ & $\begin{array}{l}2.017 \\
2.090\end{array}$ & $\begin{array}{l}0.000 \\
0.153\end{array}$ \\
\hline $\begin{array}{l}1 \\
2\end{array}$ & $\begin{array}{l}2 \\
2\end{array}$ & $\begin{array}{l}478.869 \\
403.171\end{array}$ & $\begin{array}{r}17.493 \\
2.703\end{array}$ & $\begin{array}{l}2688.822 \\
2409.359\end{array}$ & $\begin{array}{l}6.017 \\
6.148\end{array}$ & $\begin{array}{l}1.000 \\
0.906\end{array}$ \\
\hline 1 & 3 & 403.171 & 2.703 & 441.514 & 1.267 & 0.000 \\
\hline 1 & 4 & 403.171 & 2.703 & 2614.483 & 6.657 & 1.000 \\
\hline $\begin{array}{l}1 \\
2 \\
3 \\
4\end{array}$ & $\begin{array}{l}5 \\
5 \\
5 \\
5\end{array}$ & $\begin{array}{l}403.171 \\
325.572 \\
325.572 \\
325.650\end{array}$ & $\begin{array}{l}2.703 \\
0.140 \\
0.140 \\
2.703\end{array}$ & $\begin{array}{r}2494.280 \\
2139.479 \\
114.564 \\
114.888\end{array}$ & $\begin{array}{l}6.358 \\
6.587 \\
0.367 \\
0.368\end{array}$ & $\begin{array}{r}0.945 \\
0.852 \\
0.000 \\
-1.000\end{array}$ \\
\hline $\begin{array}{l}1 \\
2\end{array}$ & $\begin{array}{l}6 \\
6\end{array}$ & $\begin{array}{l}37.9 .844 \\
381.741\end{array}$ & $\begin{array}{r}2.703 \\
64.000\end{array}$ & $\begin{array}{l}342.426 \\
350.450\end{array}$ & $\begin{array}{l}1.014 \\
1.018\end{array}$ & $\begin{array}{l}-1.000 \\
-1.000\end{array}$ \\
\hline $\begin{array}{l}1 \\
2 \\
3\end{array}$ & $\begin{array}{l}7 \\
7 \\
7\end{array}$ & $\begin{array}{l}301.330 \\
301.443 \\
324.405\end{array}$ & $\begin{array}{l}0.873 \\
4.700 \\
3.700\end{array}$ & $\begin{array}{r}13.294 \\
13.765 \\
109.686\end{array}$ & $\begin{array}{l}0.044 \\
0.044 \\
0.351\end{array}$ & $\begin{array}{l}-1.000 \\
-1.000 \\
-1.000\end{array}$ \\
\hline 1 & 8 & 301.330 & 0.873 & 13.294 & 0.044 & -1.000 \\
\hline $\begin{array}{l}1 \\
2\end{array}$ & $\begin{array}{l}9 \\
9\end{array}$ & $\begin{array}{l}307.604 \\
311.000\end{array}$ & $\begin{array}{l}0.873 \\
0.873\end{array}$ & $\begin{array}{r}31.094 \\
137.512\end{array}$ & $\begin{array}{l}1.357 \\
0.081\end{array}$ & $\begin{array}{l}5.000 \\
5.000\end{array}$ \\
\hline $\begin{array}{l}1 \\
2\end{array}$ & $\begin{array}{l}10 \\
10\end{array}$ & $\begin{array}{l}549.837 \\
47.8 .869\end{array}$ & $\begin{array}{l}.61 .000 \\
17.493\end{array}$ & $\begin{array}{l}1113.933 \\
1113.933\end{array}$ & $\begin{array}{l}2.669 \\
2.728\end{array}$ & $\begin{array}{l}0.000 \\
0.178\end{array}$ \\
\hline
\end{tabular}




\section{A. 25}

Table A17

STATE POINTS FOR THE DOUBLE-FLASH CYCLE AT RESOURCE TEMPERATURE $=530^{\circ} \mathrm{F}\left(550^{\circ} \mathrm{K}\right)$

\begin{tabular}{rrrrrrrr}
\hline & & $\begin{array}{c}\text { T } \\
\text { K }\end{array}$ & L & (DEG F) & $\begin{array}{r}\text { (PSIA) } \\
\text { (BTU/LB) }\end{array}$ & $\begin{array}{c}\text { S } \\
\text { (BTU/F-LB) }\end{array}$ & $Q$ \\
\hline 1 & 1 & 402.277 & 253.713 & 377.603 & 0.571 & 0.000 \\
2 & 1 & 266.020 & 39.197 & 377.603 & 0.589 & 0.153 \\
1 & 2 & 402.277 & 253.713 & 1201.287 & 1.527 & 1.000 \\
2 & 2 & 266.020 & 39.197 & 1081.108 & 1.558 & 0.906 \\
1 & 3 & 266.020 & 39.197 & 234.869 & 0.392 & 0.000 \\
1 & 4 & 266.020 & 39.197 & 1169.318 & 1.680 & 1.000 \\
1 & 5 & 266.020 & 39.197 & 1117.627 & 1.608 & 0.945 \\
2 & 5 & 126.342 & 2.031 & 965.051 & 1.663 & 0.852 \\
3 & 5 & 126.342 & 2.031 & 94.269 & 0.177 & 0.000 \\
4 & 5 & 126.482 & 39.197 & 94.409 & 0.177 & -1.000 \\
1 & 6 & 224.031 & 39.197 & 192.258 & 0.332 & -1.000 \\
2 & 6 & 227.446 & 928.243 & 195.708 & 0.333 & -1.000 \\
1 & 7 & 82.706 & 12.662 & 50.720 & 0.100 & -1.000 \\
2 & 7 & 82.909 & 68.168 & 50.923 & 0.100 & -1.000 \\
3 & 7 & 124.241 & 53.664 & 92.172 & 0.173 & -1.000 \\
1 & 8 & 82.706 & 12.662 & 50.720 & 0.100 & -1.000 \\
1 & 9 & 93.999 & 12.662 & 58.375 & 0.414 & 5.000 \\
2 & 9 & 100.112 & 12.662 & 104.138 & 0.109 & 5.000 \\
1 & 10 & 530.019 & 884.732 & 524.032 & 0.727 & 0.000 \\
2 & 10 & 402.277 & 253.713 & 524.032 & 0.741 & 0.178 \\
\hline & & & & & &
\end{tabular}




\section{A. 26}

Tab1e Al8

FLUID FLOW RATES FOR THE DOUBLE-FLASH CYCLE AT RESOURCE TEMPERATURE $=550^{\circ} \mathrm{K}\left(530^{\circ} \mathrm{F}\right)$

\begin{tabular}{rrrrr}
\hline L & \multicolumn{1}{c}{ G } & \multicolumn{1}{c}{ G } \\
(KG/SEC) & \multicolumn{1}{c}{ (KLB/HR) } & $\begin{array}{l}\text { Fluid } \\
\text { Number }\end{array}$ & $\begin{array}{c}\text { Fluid } \\
\text { Description }\end{array}$ \\
\hline 1 & 48.69795 & 386.49812 & 1 & Water \\
2 & 10.52891 & 83.56414 & 1 & Water \\
3 & 41.25948 & 327.46162 & 1 & Water \\
4 & 7.43848 & 59.03650 & 1 & Water \\
5 & 17.96738 & 142.60064 & 1 & Water \\
6 & 59.22686 & 470.06227 & 1 & Water \\
7 & 379.29703 & 3010.34399 & 1 & Water \\
8 & 14.44356 & 114.63332 & 1 & Water \\
9 & 345.73397 & 2743.96605 & 7 & Atmospheric Air \\
10 & 59.22686 & 470.06227 & 1 & Water \\
\hline
\end{tabular}




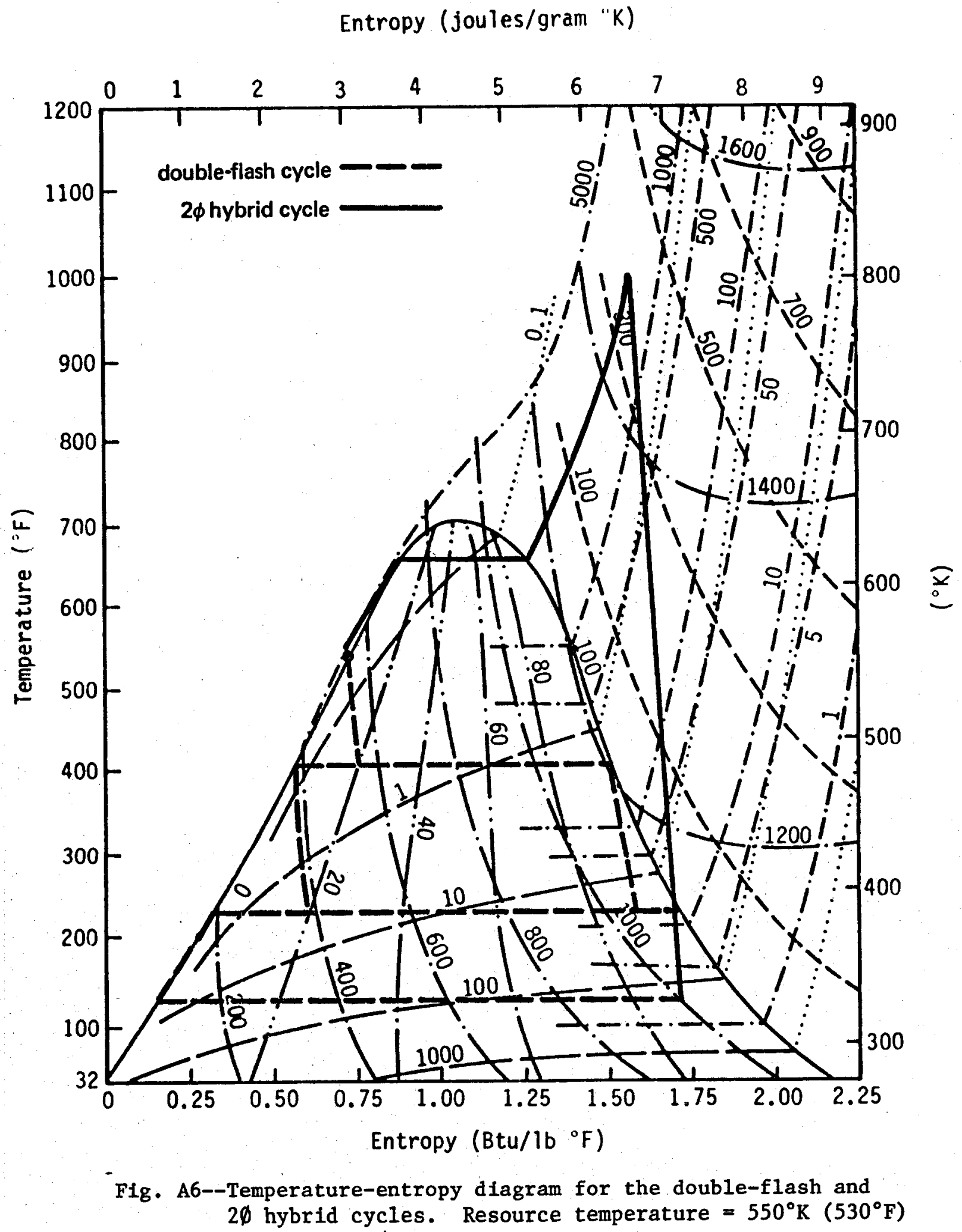


Table A19

STATE POINTS FOR THE $2 \emptyset$ HYBRID CYCLE AT RESOURCE TEMPERATURE $=588^{\circ} \mathrm{K}\left(598^{\circ} \mathrm{F}\right)$

\begin{tabular}{|c|c|c|c|c|c|c|}
\hline $\mathbf{K}$ & $\mathbf{L}$ & $\stackrel{\text { T }}{\text { (DEG } K \text { ) }}$ & $\stackrel{P}{P}$ & $\underset{(J / G)}{H}$ & $\begin{array}{c}S \\
(\mathrm{~J} / \mathrm{GK})\end{array}$ & $Q$ \\
\hline $\begin{array}{l}1 \\
2\end{array}$ & $\begin{array}{l}1 \\
1\end{array}$ & $\begin{array}{l}307.604 \\
480.000\end{array}$ & $\begin{array}{l}0.873 \\
0.873\end{array}$ & $\begin{array}{r}9.476 \\
370.276\end{array}$ & $\begin{array}{l}0.070 \\
2.744\end{array}$ & $\begin{array}{r}5.000 \\
-2.000\end{array}$ \\
\hline $\begin{array}{l}1 \\
2\end{array}$ & $\begin{array}{l}2 \\
2\end{array}$ & $\begin{array}{l}307.604 \\
480.000\end{array}$ & $\begin{array}{l}0.873 \\
0.873\end{array}$ & $\begin{array}{r}9.476 \\
182.468\end{array}$ & $\begin{array}{l}0.070 \\
0.517\end{array}$ & $\begin{array}{l}5.000 \\
5.000\end{array}$ \\
\hline $\begin{array}{l}1 \\
2\end{array}$ & $\begin{array}{l}3 \\
3\end{array}$ & $\begin{array}{l}2324.444 \\
1624.047\end{array}$ & $\begin{array}{l}0.873 \\
0.873\end{array}$ & $\begin{array}{l}2595.813 \\
1698.555\end{array}$ & $\begin{array}{l}2.668 \\
2.209\end{array}$ & $\begin{array}{l}5.000 \\
5.000\end{array}$ \\
\hline $\begin{array}{l}1 \\
2 \\
3\end{array}$ & $\begin{array}{l}4 \\
4 \\
4\end{array}$ & $\begin{array}{l}325.572 \\
325.572 \\
330.090\end{array}$ & $\begin{array}{r}0.140 \\
0.140 \\
149.964\end{array}$ & $\begin{array}{r}2205.793 \\
114.564 \\
133.447\end{array}$ & $\begin{array}{l}6.790 \\
0.367 \\
0.379\end{array}$ & $\begin{array}{r}0.880 \\
0.000 \\
-1.000\end{array}$ \\
\hline $\begin{array}{l}1 \\
2\end{array}$ & $\begin{array}{l}5 \\
5\end{array}$ & $\begin{array}{l}352.028 \\
350.756\end{array}$ & $\begin{array}{l}149.964 \\
108.100\end{array}$ & $\begin{array}{l}225.312 \\
219.977\end{array}$ & $\begin{array}{l}0.651 \\
0.648\end{array}$ & $\begin{array}{l}-1.000 \\
-1.000\end{array}$ \\
\hline $\begin{array}{l}1 \\
2 \\
3 \\
4\end{array}$ & $\begin{array}{l}6 \\
6 \\
6 \\
6\end{array}$ & $\begin{array}{l}301.330 \\
301.443 \\
320.572 \\
301.330\end{array}$ & $\begin{array}{l}0.873 \\
4.700 \\
3.700 \\
0.873\end{array}$ & $\begin{array}{l}13.294 \\
13.765 \\
93.673 \\
13.294\end{array}$ & $\begin{array}{l}0.044 \\
0.044 \\
0.302 \\
0.044\end{array}$ & $\begin{array}{l}-1.000 \\
-1.000 \\
-1.000 \\
-1.000\end{array}$ \\
\hline 1 & 7 & 299.827 & 0.873 & 7.010 & 0.023 & -1.000 \\
\hline $\begin{array}{l}1 \\
2\end{array}$ & $\begin{array}{l}8 \\
8\end{array}$ & $\begin{array}{l}307.604 \\
311.000\end{array}$ & $\begin{array}{l}0.873 \\
0.873\end{array}$ & $\begin{array}{r}31.094 \\
137.512\end{array}$ & $\begin{array}{l}1.357 \\
0.081\end{array}$ & $\begin{array}{l}5.000 \\
5.000\end{array}$ \\
\hline $\begin{array}{l}1 \\
2\end{array}$ & $\begin{array}{l}9 \\
9\end{array}$ & $\begin{array}{l}594.951 \\
472.550\end{array}$ & $\begin{array}{l}0.873 \\
0.873\end{array}$ & $\begin{array}{l}380.208 \\
223.405\end{array}$ & $\begin{array}{l}0.923 \\
0.628\end{array}$ & $\begin{array}{l}5.000 \\
5.000\end{array}$ \\
\hline $\begin{array}{l}1 \\
2 \\
3\end{array}$ & $\begin{array}{l}10 \\
10 \\
10\end{array}$ & $\begin{array}{l}587.816 \\
589.186 \\
615.340\end{array}$ & $\begin{array}{l}105.000 \\
149.964 \\
149.964\end{array}$ & $\begin{array}{l}1324.120 \\
1332.417 \\
2436.932\end{array}$ & $\begin{array}{l}3.028 \\
3.030 \\
4.830\end{array}$ & $\begin{array}{r}0.000 \\
-1.000 \\
0.933\end{array}$ \\
\hline $\begin{array}{l}1 \\
2\end{array}$ & $\begin{array}{l}11 \\
11\end{array}$ & $\begin{array}{l}615.340 \\
615.340\end{array}$ & $\begin{array}{l}149.964 \\
149.964\end{array}$ & $\begin{array}{l}1505.505 \\
1505.505\end{array}$ & $\begin{array}{l}3.317 \\
3.317\end{array}$ & $\begin{array}{l}0.000 \\
0.000\end{array}$ \\
\hline $\begin{array}{l}1 \\
2\end{array}$ & $\begin{array}{l}12 \\
12\end{array}$ & $\begin{array}{l}810.037 \\
325.572\end{array}$ & $\begin{array}{r}149.464 \\
0.140\end{array}$ & $\begin{array}{l}3309.441 \\
2205.793\end{array}$ & $\begin{array}{l}6.112 \\
6.790\end{array}$ & $\begin{array}{l}2.000 \\
0.880\end{array}$ \\
\hline $\begin{array}{l}1 \\
2\end{array}$ & $\begin{array}{l}13 \\
13\end{array}$ & $\begin{array}{l}810.037 \\
325.572\end{array}$ & $\begin{array}{r}149.464 \\
0.140\end{array}$ & $\begin{array}{l}3309.441 \\
2205.793\end{array}$ & $\begin{array}{l}6.112 \\
6.790\end{array}$ & $\begin{array}{l}2.000 \\
0.880\end{array}$ \\
\hline 1 & 14 & 1624.047 & 0.873 & 1698.555 & 2.209 & 5.000 \\
\hline $\begin{array}{l}1 \\
2\end{array}$ & $\begin{array}{l}15 \\
15\end{array}$ & $\begin{array}{r}1624.047 \\
594.845\end{array}$ & $\begin{array}{l}0.873 \\
0.873\end{array}$ & $\begin{array}{r}1698.555 \\
380.073\end{array}$ & $\begin{array}{l}2.209 \\
0.922\end{array}$ & $\begin{array}{l}5.000 \\
5.000\end{array}$ \\
\hline $\begin{array}{l}1 \\
2\end{array}$ & $\begin{array}{l}16 \\
16\end{array}$ & $\begin{array}{l}615.340 \\
810.037\end{array}$ & $\begin{array}{l}149.964 \\
149.464\end{array}$ & $\begin{array}{l}2503.771 \\
3309.441\end{array}$ & $\begin{array}{l}4.939 \\
6.112\end{array}$ & $\begin{array}{l}1.000 \\
2.000\end{array}$ \\
\hline
\end{tabular}


Table A20

STATE POINTS FOR THE $2 \emptyset$ HYBRID CYCLE AT RESOURCE TEMPERATURE $=598^{\circ} \mathrm{F}\left(588^{\circ} \mathrm{K}\right)$

\begin{tabular}{|c|c|c|c|c|c|c|}
\hline $\mathrm{K}$ & $\mathbf{L}$ & $\left(\begin{array}{c}T \\
(D E G ~ F)\end{array}\right.$ & $\begin{array}{c}P \\
\text { (PSIA) }\end{array}$ & $\begin{array}{c}\mathrm{H} \\
(\mathrm{BTU} / \mathrm{LB})\end{array}$ & $\begin{array}{c}\mathrm{S} \\
(\mathrm{BTU} / \mathrm{F}-\mathrm{LB})\end{array}$ & $\mathbf{Q}$ \\
\hline $\begin{array}{l}1 \\
2\end{array}$ & $\begin{array}{l}1 \\
1\end{array}$ & $\begin{array}{r}93.999 \\
404.312\end{array}$ & $\begin{array}{l}12.662 \\
12.662\end{array}$ & $\begin{array}{r}49.078 \\
204.234\end{array}$ & $\begin{array}{l}0.106 \\
0.745\end{array}$ & $\begin{array}{r}5.000 \\
-2.000\end{array}$ \\
\hline $\begin{array}{l}1 \\
2\end{array}$ & $\begin{array}{l}2 \\
2\end{array}$ & $\begin{array}{r}93.999 \\
404.312\end{array}$ & $\begin{array}{l}12.662 \\
12.662\end{array}$ & $\begin{array}{r}49.078 \\
123.471\end{array}$ & $\begin{array}{l}0.106 \\
0.213\end{array}$ & $\begin{array}{l}5.000 \\
5.000\end{array}$ \\
\hline $\begin{array}{l}1 \\
2\end{array}$ & $\begin{array}{l}3 \\
3\end{array}$ & $\begin{array}{l}3724.312 \\
2463.597\end{array}$ & $\begin{array}{l}12.662 \\
12.662\end{array}$ & $\begin{array}{r}1161.290 \\
775.438\end{array}$ & $\begin{array}{l}0.727 \\
0.617\end{array}$ & $\begin{array}{l}5.000 \\
5.000\end{array}$ \\
\hline $\begin{array}{l}1 \\
2 \\
3\end{array}$ & $\begin{array}{l}4 \\
4 \\
4\end{array}$ & $\begin{array}{l}126.342 \\
126.342 \\
134.474\end{array}$ & $\begin{array}{r}2.031 \\
2.031 \\
2175.047\end{array}$ & $\begin{array}{r}993.568 \\
94.269 \\
102.390\end{array}$ & $\begin{array}{l}1.712 \\
0.177 \\
0.180\end{array}$ & $\begin{array}{r}0.880 \\
0.000 \\
-1.000\end{array}$ \\
\hline $\begin{array}{l}1 \\
2\end{array}$ & $\begin{array}{l}5 \\
5\end{array}$ & $\begin{array}{l}173.963 \\
171.674\end{array}$ & $\begin{array}{l}2175.047 \\
1567.861\end{array}$ & $\begin{array}{l}141.895 \\
139.601\end{array}$ & $\begin{array}{l}0.245 \\
0.244\end{array}$ & $\begin{array}{l}-1.000 \\
-1.000\end{array}$ \\
\hline $\begin{array}{l}1 \\
2 \\
3 \\
4\end{array}$ & $\begin{array}{l}6 \\
6 \\
6 \\
6\end{array}$ & $\begin{array}{r}82.706 \\
82.909 \\
117.342 \\
82.706\end{array}$ & $\begin{array}{l}12.662 \\
68.168 \\
53.664 \\
12.662\end{array}$ & $\begin{array}{l}50.720 \\
50.923 \\
85.286 \\
50.720\end{array}$ & $\begin{array}{l}0.100 \\
0.100 \\
0.162 \\
0.100\end{array}$ & $\begin{array}{l}-1.000 \\
-1.000 \\
-1.000 \\
-1.000\end{array}$ \\
\hline 1 & 7 & 80.001 & 12.662 & 48.018 & 0.095 & -1.000 \\
\hline $\begin{array}{l}1 \\
2\end{array}$ & $\begin{array}{l}8 \\
8\end{array}$ & $\begin{array}{r}93.999 \\
100.112\end{array}$ & $\begin{array}{l}12.662 \\
12.662\end{array}$ & $\begin{array}{r}58.375 \\
104.138\end{array}$ & $\begin{array}{l}0.414 \\
0.109\end{array}$ & $\begin{array}{l}5.000 \\
5.000\end{array}$ \\
\hline $\begin{array}{l}1 \\
2\end{array}$ & $\begin{array}{l}9 \\
9\end{array}$ & $\begin{array}{l}611.223 \\
390.903\end{array}$ & $\begin{array}{l}12.662 \\
12.662\end{array}$ & $\begin{array}{l}208.505 \\
141.075\end{array}$ & $\begin{array}{l}0.310 \\
0.239\end{array}$ & $\begin{array}{l}5.000 \\
5.000\end{array}$ \\
\hline $\begin{array}{l}1 \\
2 \\
3\end{array}$ & $\begin{array}{l}10 \\
10 \\
10\end{array}$ & $\begin{array}{l}598.380 \\
600.847 \\
647.924\end{array}$ & $\begin{array}{l}1522.899 \\
2175.047 \\
2175.047\end{array}$ & $\begin{array}{r}614.419 \\
617.987 \\
1092.966\end{array}$ & $\begin{array}{l}0.813 \\
0.813 \\
1.243\end{array}$ & $\begin{array}{r}0.000 \\
-1.000 \\
0.933\end{array}$ \\
\hline $\begin{array}{l}1 \\
2\end{array}$ & $\begin{array}{l}11 \\
11\end{array}$ & $\begin{array}{l}647.924 \\
647.924\end{array}$ & $\begin{array}{l}2175.047 \\
2175.047\end{array}$ & $\begin{array}{l}692.421 \\
692.421\end{array}$ & $\begin{array}{l}0.882 \\
0.882\end{array}$ & $\begin{array}{l}0.000 \\
0.000\end{array}$ \\
\hline $\begin{array}{l}1 \\
2\end{array}$ & $\begin{array}{l}12 \\
12\end{array}$ & $\begin{array}{l}998.379 \\
126.342\end{array}$ & $\begin{array}{r}2167.795 \\
2.031\end{array}$ & $\begin{array}{r}1468.174 \\
993.568\end{array}$ & $\begin{array}{l}1.550 \\
1.712\end{array}$ & $\begin{array}{l}2.000 \\
0.880\end{array}$ \\
\hline $\begin{array}{l}1 \\
2\end{array}$ & $\begin{array}{l}13 \\
13\end{array}$ & $\begin{array}{l}998.379 \\
126.342\end{array}$ & $\begin{array}{r}2167.795 \\
2.031\end{array}$ & $\begin{array}{r}1468.174 \\
993.568\end{array}$ & $\begin{array}{l}1.550 \\
1.712\end{array}$ & $\begin{array}{l}2.000 \\
0.880\end{array}$ \\
\hline 1 & 14 & 2463.597 & 12.662 & 775.438 & 0.617 & 5.000 \\
\hline $\begin{array}{l}1 \\
2\end{array}$ & $\begin{array}{l}15 \\
15\end{array}$ & $\begin{array}{r}2463.597 \\
611.033\end{array}$ & $\begin{array}{l}12.662 \\
12.662\end{array}$ & $\begin{array}{l}775.438 \\
208.447\end{array}$ & $\begin{array}{l}0.617 \\
0.310\end{array}$ & $\begin{array}{l}5.000 \\
5.000\end{array}$ \\
\hline $\begin{array}{l}1 \\
2\end{array}$ & $\begin{array}{l}16 \\
16\end{array}$ & $\begin{array}{l}647.924 \\
998.379\end{array}$ & $\begin{array}{l}2175.047 \\
2167.795\end{array}$ & $\begin{array}{l}1121.708 \\
1468.174\end{array}$ & $\begin{array}{l}1.269 \\
1.550\end{array}$ & $\begin{array}{l}1.000 \\
2.000\end{array}$ \\
\hline
\end{tabular}


Table A21

STREAM FLOW RATES FOR THE $2 \emptyset$ HYBRID CYCLE AT RESOURCE TEMPERATURE $=588^{\circ} \mathrm{K}\left(598^{\circ} \mathrm{F}\right)$

\begin{tabular}{rrrrc}
\hline \multicolumn{1}{r}{ L } & \multicolumn{1}{c}{ G } & \multicolumn{1}{c}{ G } & Fluid & \multicolumn{1}{c}{$\begin{array}{c}\text { Fluid } \\
\text { Description }\end{array}$} \\
\hline 1 & 5.03992 & 40.00000 & 7 & Coal \\
2 & 48.81438 & 387.42217 & 7 & Atmospheric Air \\
3 & 53.85430 & 427.42217 & 6 & Flue Gases \\
4 & 59.97647 & 476.01161 & 1 & Water \\
5 & 64.28033 & 510.16988 & 1 & Water \\
6 & 1569.61474 & 12457.46717 & 1 & Water \\
7 & 49.71800 & 394.59385 & 1 & Water \\
8 & 1190.09464 & 9445.35271 & 7 & Atmospheric Air \\
9 & 53.85430 & 427.42217 & 6 & Flue Gases \\
10 & 64.28033 & 510.16988 & 1 & Water \\
11 & 4.30387 & 34.15826 & 1 & Water \\
12 & 29.98823 & 238.00581 & 1 & Water \\
13 & 29.98823 & 238.00581 & 1 & Water \\
14 & 0.00551 & 0.04375 & 6 & Flue Gases \\
15 & 53.84878 & 427.37841 & 6 & Flue Gases \\
16 & 59.97647 & 476.01161 & 1 & Water \\
\hline & & & &
\end{tabular}




\section{A. 31}

Table A22

STATE POINTS FOR THE DOUBLE-FLASH CYCLE AT RESOURCE TEMPERATURE $=588^{\circ} \mathrm{K}\left(598^{\circ} \mathrm{F}\right)$

\begin{tabular}{|c|c|c|c|c|c|c|}
\hline $\mathbf{K}$ & $\mathbf{L}$ & $\begin{array}{c}\text { T } \\
(\mathrm{DEG} K)\end{array}$ & $\begin{array}{c}P \\
(B A R)\end{array}$ & $\begin{array}{c}\mathrm{H} \\
(\mathrm{J} / \mathrm{G})\end{array}$ & $\underset{(\mathrm{J} / \mathrm{GK})}{S}$ & $\mathbf{Q}$ \\
\hline $\begin{array}{l}1 \\
2\end{array}$ & $\begin{array}{l}1 \\
1\end{array}$ & $\begin{array}{l}481.735 \\
401.570\end{array}$ & $\begin{array}{r}18.543 \\
2.581\end{array}$ & $\begin{array}{l}786.452 \\
786.452\end{array}$ & $\begin{array}{l}2.044 \\
2.126\end{array}$ & $\begin{array}{l}0.000 \\
0.162\end{array}$ \\
\hline $\begin{array}{l}1 \\
2\end{array}$ & $\begin{array}{l}2 \\
2\end{array}$ & $\begin{array}{l}481.735 \\
401.570\end{array}$ & $\begin{array}{r}18.543 \\
2.581\end{array}$ & $\begin{array}{l}2690.208 \\
2396.341\end{array}$ & $\begin{array}{l}5.996 \\
6.135\end{array}$ & $\begin{array}{l}1.000 \\
0.901\end{array}$ \\
\hline 1 & 3 & 401.570 & 2.581 & 434.687 & 1.250 & 0.000 \\
\hline 1 & 4 & 401.570 & 2.581 & 2612.275 & 6.673 & 1.000 \\
\hline $\begin{array}{l}1 \\
2 \\
3 \\
4\end{array}$ & $\begin{array}{l}5 \\
5 \\
5 \\
5\end{array}$ & $\begin{array}{l}401.570 \\
325.572 \\
325.572 \\
325.646\end{array}$ & $\begin{array}{l}2.581 \\
0.140 \\
0.140 \\
2.581\end{array}$ & $\begin{array}{r}2459.177 \\
2116.708 \\
114.564 \\
114.871\end{array}$ & $\begin{array}{l}6.292 \\
6.517 \\
0.367 \\
0.368\end{array}$ & $\begin{array}{r}0.930 \\
0.842 \\
0.000 \\
-1.000\end{array}$ \\
\hline $\begin{array}{l}1 \\
2\end{array}$ & $\begin{array}{l}6 \\
6\end{array}$ & $\begin{array}{l}371.522 \\
374.768\end{array}$ & $\begin{array}{r}2.581 \\
108.000\end{array}$ & $\begin{array}{l}307.290 \\
320.982\end{array}$ & $\begin{array}{l}0.920 \\
0.928\end{array}$ & $\begin{array}{l}-1.000 \\
-1.000\end{array}$ \\
\hline $\begin{array}{l}1 \\
2 \\
3\end{array}$ & $\begin{array}{l}7 \\
7 \\
7\end{array}$ & $\begin{array}{l}301.330 \\
301.443 \\
324.405\end{array}$ & $\begin{array}{l}0.873 \\
4.700 \\
3.700\end{array}$ & $\begin{array}{r}13.294 \\
13.765 \\
109.686\end{array}$ & $\begin{array}{l}0.044 \\
0.044 \\
0.351\end{array}$ & $\begin{array}{l}-1.000 \\
-1.000 \\
-1.000\end{array}$ \\
\hline 1 & 8 & 301.330 & 0.873 & 13.294 & 0.044 & -1.000 \\
\hline $\begin{array}{l}1 \\
2\end{array}$ & $\begin{array}{l}9 \\
9\end{array}$ & $\begin{array}{l}307.604 \\
311.000\end{array}$ & $\begin{array}{l}0.873 \\
0.873\end{array}$ & $\begin{array}{r}31.094 \\
137.512\end{array}$ & $\begin{array}{l}1.357 \\
0.081\end{array}$ & $\begin{array}{l}5.000 \\
5.000\end{array}$ \\
\hline $\begin{array}{l}1 \\
2\end{array}$ & $\begin{array}{l}10 \\
10\end{array}$ & $\begin{array}{l}587.816 \\
481.735\end{array}$ & $\begin{array}{r}105.000 \\
18.543\end{array}$ & $\begin{array}{l}1324.120 \\
1324.120\end{array}$ & $\begin{array}{l}3.028 \\
3.160\end{array}$ & $\begin{array}{l}0.000 \\
0.282\end{array}$ \\
\hline
\end{tabular}


Table A23

STATE POINTS FOR THE DOUBLE-FLASH CYCLE AT RESOURCE TEMPERATURE $=598^{\circ} \mathrm{F}\left(588^{\circ} \mathrm{K}\right)$

\begin{tabular}{|c|c|c|c|c|c|c|}
\hline $\mathbf{K}$ & $\mathbf{L}$ & $\begin{array}{c}\mathrm{T} \\
(\mathrm{DEG}\end{array}$ & $\begin{array}{c}\text { P } \\
(\text { PSIA) }\end{array}$ & (BTU/LB) & $\frac{\mathrm{S}}{(\mathrm{BTU} / \mathrm{F}-\mathrm{LB})}$ & $Q$ \\
\hline $\begin{array}{l}1 \\
2\end{array}$ & $\begin{array}{l}1 \\
1\end{array}$ & $\begin{array}{l}407.435 \\
263.138\end{array}$ & $\begin{array}{r}268.943 \\
37.429\end{array}$ & $\begin{array}{l}383.204 \\
383.204\end{array}$ & $\begin{array}{l}0.578 \\
0.597\end{array}$ & $\begin{array}{l}0.000 \\
0.162\end{array}$ \\
\hline $\begin{array}{l}1 \\
2\end{array}$ & $\begin{array}{l}2 \\
2\end{array}$ & $\begin{array}{l}407.435 \\
263.138\end{array}$ & $\begin{array}{r}268.943 \\
37.429\end{array}$ & $\begin{array}{l}1201.883 \\
1075.510\end{array}$ & $\begin{array}{l}1.522 \\
1.555\end{array}$ & $\begin{array}{l}1.000 \\
0.901\end{array}$ \\
\hline 1 & 3 & 263.138 & 37.429 & 231.933 & 0.388 & 0.000 \\
\hline 1 & 4 & 263.138 & 37.429 & 1168.369 & 1.684 & 1.000 \\
\hline $\begin{array}{l}1 \\
2 \\
3 \\
4\end{array}$ & $\begin{array}{l}5 \\
5 \\
5 \\
5\end{array}$ & $\begin{array}{l}263.138 \\
126.342 \\
126.342 \\
126.475\end{array}$ & $\begin{array}{r}37.429 \\
2.031 \\
2.031 \\
37.429\end{array}$ & $\begin{array}{r}1102.532 \\
955.258 \\
94.269 \\
94.402\end{array}$ & $\begin{array}{l}1.592 \\
1.646 \\
0.177 \\
0.177\end{array}$ & $\begin{array}{r}0.930 \\
0.842 \\
0.000 \\
-1.000\end{array}$ \\
\hline $\begin{array}{l}1 \\
2\end{array}$ & $\begin{array}{l}6 \\
6\end{array}$ & $\begin{array}{l}209.052 \\
214.894\end{array}$ & $\begin{array}{r}37.429 \\
1566.410\end{array}$ & $\begin{array}{l}177.148 \\
183.036\end{array}$ & $\begin{array}{l}0.309 \\
0.311\end{array}$ & $\begin{array}{l}-1.000 \\
-1.000\end{array}$ \\
\hline $\begin{array}{l}1 \\
2 \\
3\end{array}$ & $\begin{array}{l}7 \\
7 \\
7\end{array}$ & $\begin{array}{r}82.706 \\
82.909 \\
124.241\end{array}$ & $\begin{array}{l}12.662 \\
68.168 \\
53.664\end{array}$ & $\begin{array}{l}50.720 \\
50.923 \\
92.172\end{array}$ & $\begin{array}{l}0.100 \\
0.100 \\
0.173\end{array}$ & $\begin{array}{l}-1.000 \\
-1.000 \\
-1.000\end{array}$ \\
\hline 1 & 8 & 82.706 & 12.662 & 50.720 & 0.100 & -1.000 \\
\hline $\begin{array}{l}1 \\
2\end{array}$ & $\begin{array}{l}9 \\
9\end{array}$ & $\begin{array}{r}93.999 \\
100.112\end{array}$ & $\begin{array}{l}12.662 \\
12.662\end{array}$ & $\begin{array}{r}58.375 \\
104.138\end{array}$ & $\begin{array}{l}0.414 \\
0.109\end{array}$ & $\begin{array}{l}5.000 \\
5.000\end{array}$ \\
\hline $\begin{array}{l}1 \\
2\end{array}$ & $\begin{array}{l}10 \\
10\end{array}$ & $\begin{array}{l}598.380 \\
407.435\end{array}$ & $\begin{array}{r}1522.899 \\
268.943\end{array}$ & $\begin{array}{l}614.419 \\
614.419\end{array}$ & $\begin{array}{l}0.813 \\
0.844\end{array}$ & $\begin{array}{l}0.000 \\
0.282\end{array}$ \\
\hline
\end{tabular}




\section{A. 33}

Table A24

FLUID FLOW RATES FOR THE DOUBLE-FLASH CYCLE AT RESOURCE TEMPERATURE $=588^{\circ} \mathrm{K}\left(598^{\circ} \mathrm{F}\right)$

\begin{tabular}{rrrrr}
\hline L & $\begin{array}{c}\text { G } \\
(\mathrm{KG} / \mathrm{SEC})\end{array}$ & \multicolumn{1}{c}{$\begin{array}{c}\text { G } \\
(\mathrm{KLB} / \mathrm{HR})\end{array}$} & $\begin{array}{l}\text { Fluid } \\
\text { Number }\end{array}$ & $\begin{array}{c}\text { Fluid } \\
\text { Description }\end{array}$ \\
\hline 1 & 46.12597 & 366.08519 & 1 & Water \\
2 & 18.15436 & 144.08465 & 1 & Water \\
3 & 38.67482 & 306.94816 & 1 & Water \\
4 & 7.45114 & 59.13703 & 1 & Water \\
5 & 25.60551 & 203.22168 & 1 & Water \\
6 & 64.28033 & 510.16984 & 1 & Water \\
7 & 534.46154 & 4241.82885 & 1 & Water \\
8 & 20.35219 & 161.52803 & 1 & Water \\
9 & 487.16835 & 3866.47985 & 7 & Atmospheric Air \\
10 & 64.28033 & 510.16984 & 1 & Water \\
\hline
\end{tabular}




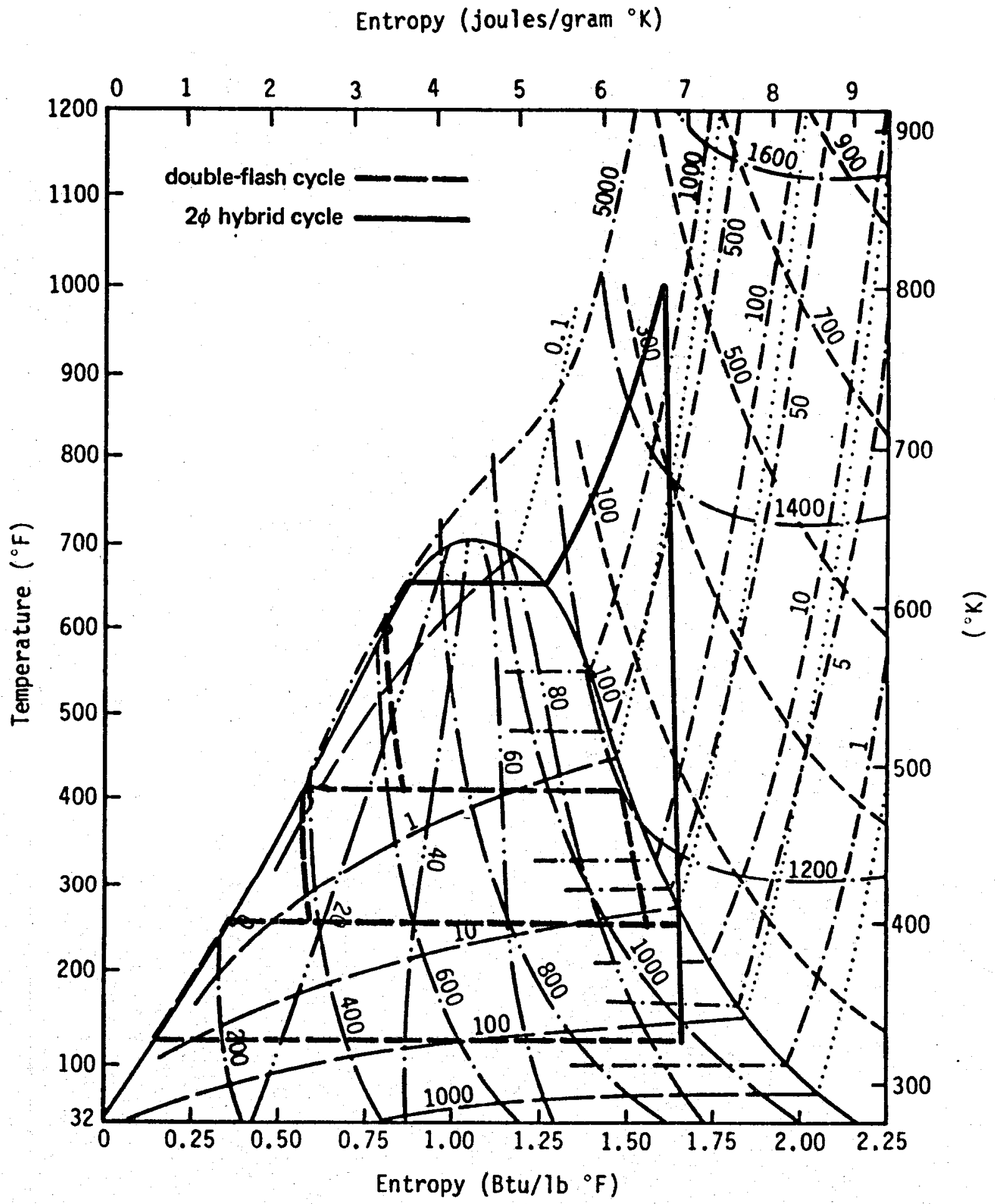

Fig. A7--Temperature-entropy diagram for the double-flash and 20 hybrid cycles. Resource temperature $=588^{\circ} \mathrm{K}\left(598^{\circ} \mathrm{F}\right)$ 
A. 35

Table A25

STATE POINTS FOR THE COAL-FIRED TWO-STAGE REGENERATION, SINGLE REHEAT POWER CYCLE

\begin{tabular}{|c|c|c|c|c|c|c|}
\hline $\mathbf{K}$ & $\mathbf{L}$ & $\stackrel{\mathbf{T}}{\text { (DEG K) }}$ & $\begin{array}{c}\mathrm{P} \\
\text { (BAR) }\end{array}$ & $\underset{(\mathrm{J} / \mathrm{G})}{\mathrm{H}}$ & $\underset{(\mathrm{J} / \mathrm{GK})}{S}$ & $\mathbf{Q}$ \\
\hline $\begin{array}{l}1 \\
2\end{array}$ & $\begin{array}{l}1 \\
1\end{array}$ & $\begin{array}{l}307.604 \\
480.000\end{array}$ & $\begin{array}{l}0.873 \\
0.873\end{array}$ & $\begin{array}{r}9.476 \\
370.276\end{array}$ & $\begin{array}{l}0.070 \\
2.744\end{array}$ & $\begin{array}{r}5.000 \\
-2.000\end{array}$ \\
\hline $\begin{array}{l}1 \\
2\end{array}$ & $\begin{array}{l}2 \\
2\end{array}$ & $\begin{array}{l}307.604 \\
480.000\end{array}$ & $\begin{array}{l}0.873 \\
0.873\end{array}$ & $\begin{array}{r}9.476 \\
182.468\end{array}$ & $\begin{array}{l}0.070 \\
0.517\end{array}$ & $\begin{array}{l}5.000 \\
5.000\end{array}$ \\
\hline 1 & 3 & 2324.444 & 0.873 & 2595.813 & 2.668 & 5.000 \\
\hline $\begin{array}{l}1 \\
2 \\
3 \\
4 \\
5 \\
6 \\
7 \\
8 \\
9 \\
10\end{array}$ & $\begin{array}{l}4 \\
4 \\
4 \\
4 \\
4 \\
4 \\
4 \\
4 \\
4 \\
4\end{array}$ & $\begin{array}{l}325.572 \\
326.028 \\
468.875 \\
468.875 \\
473.619 \\
473.619 \\
473.622 \\
686.585 \\
811.000 \\
724.656\end{array}$ & $\begin{array}{r}0.140 \\
15.204 \\
14.204 \\
14.204 \\
162.510 \\
162.510 \\
162.510 \\
155.510 \\
152.510 \\
87.766\end{array}$ & $\begin{array}{r}114.564 \\
116.467 \\
728.355 \\
728.355 \\
749.688 \\
749.688 \\
749.701 \\
2913.437 \\
3308.737 \\
3160.512\end{array}$ & $\begin{array}{l}0.367 \\
0.369 \\
1.923 \\
1.923 \\
1.932 \\
1.932 \\
1.932 \\
5.563 \\
6.103 \\
6.139\end{array}$ & $\begin{array}{r}0.000 \\
-1.000 \\
0.000 \\
0.000 \\
-1.000 \\
-1.000 \\
-1.000 \\
2.000 \\
2.000 \\
2.000\end{array}$ \\
\hline $\begin{array}{l}1 \\
2 \\
3\end{array}$ & $\begin{array}{l}5 \\
5 \\
5\end{array}$ & $\begin{array}{l}724.656 \\
716.003 \\
666.542\end{array}$ & $\begin{array}{l}87.766 \\
86.766 \\
12.582\end{array}$ & $\begin{array}{l}3160.512 \\
3139.311 \\
3139.311\end{array}$ & $\begin{array}{l}6.139 \\
6.114 \\
6.963\end{array}$ & $\begin{array}{l}2.000 \\
2.000 \\
2.000\end{array}$ \\
\hline $\begin{array}{l}1 \\
2 \\
3\end{array}$ & $\begin{array}{l}6 \\
6 \\
6\end{array}$ & $\begin{array}{l}724.656 \\
811.000 \\
559.590\end{array}$ & $\begin{array}{l}87.766 \\
85.766 \\
12.582\end{array}$ & $\begin{array}{l}3160.512 \\
3378.715 \\
2909.299\end{array}$ & $\begin{array}{l}6.139 \\
6.434 \\
6.587\end{array}$ & $\begin{array}{l}2.000 \\
2.000 \\
2.000\end{array}$ \\
\hline $\begin{array}{l}1 \\
2\end{array}$ & $\begin{array}{l}7 \\
7\end{array}$ & $\begin{array}{l}559.590 \\
325.572\end{array}$ & $\begin{array}{r}12.582 \\
0.140\end{array}$ & $\begin{array}{l}2909.299 \\
2262.604\end{array}$ & $\begin{array}{l}6.587 \\
6.965\end{array}$ & $\begin{array}{l}2.000 \\
0.904\end{array}$ \\
\hline 1 & 8 & 559.590 & 12.582 & 2909.299 & 6.587 & 2.000 \\
\hline 1 & 9 & 559.849 & 12.582 & 2909.868 & 6.588 & 2.000 \\
\hline 1 & 10 & 0.000 & 69.000 & 0.000 & 0.000 & $-I$ \\
\hline $\begin{array}{l}1 \\
2 \\
3 \\
4\end{array}$ & $\begin{array}{l}11 \\
11 \\
11 \\
11\end{array}$ & $\begin{array}{l}301.330 \\
301.414 \\
322.558 \\
301.330\end{array}$ & $\begin{array}{l}0.873 \\
3.700 \\
3.700 \\
0.873\end{array}$ & $\begin{array}{r}13.294 \\
13.645 \\
101.969 \\
13.294\end{array}$ & $\begin{array}{l}0.044 \\
0.044 \\
0.328 \\
0.044\end{array}$ & $\begin{array}{l}-1.000 \\
-1.000 \\
-1.000 \\
-1.000\end{array}$ \\
\hline $\begin{array}{l}1 \\
2\end{array}$ & $\begin{array}{l}12 \\
12\end{array}$ & $\begin{array}{l}307.604 \\
310.939\end{array}$ & $\begin{array}{l}0.873 \\
0.873\end{array}$ & $\begin{array}{r}31.094 \\
137.010\end{array}$ & $\begin{array}{l}1.357 \\
0.081\end{array}$ & $\begin{array}{l}5.000 \\
5.000\end{array}$ \\
\hline 1 & 13 & 299.827 & 0.873 & 7.010 & 0.023 & -1.000 \\
\hline $\begin{array}{l}1 \\
2\end{array}$ & $\begin{array}{l}14 \\
14\end{array}$ & $\begin{array}{l}559.849 \\
558.521\end{array}$ & $\begin{array}{l}12.582 \\
11.582\end{array}$ & $\begin{array}{l}2909.868 \\
2909.868\end{array}$ & $\begin{array}{l}6.588 \\
6.625\end{array}$ & $\begin{array}{l}2.000 \\
2.000\end{array}$ \\
\hline $\begin{array}{l}1 \\
2\end{array}$ & $\begin{array}{l}15 \\
15\end{array}$ & $\begin{array}{l}559.849 \\
331.068\end{array}$ & $\begin{array}{l}12.582 \\
11.582\end{array}$ & $\begin{array}{r}2909.868 \\
137.536\end{array}$ & $\begin{array}{l}6.588 \\
0.434\end{array}$ & $\begin{array}{r}2.000 \\
-1.000\end{array}$ \\
\hline $\begin{array}{l}1 \\
2\end{array}$ & $\begin{array}{l}16 \\
16\end{array}$ & $\begin{array}{l}459.501 \\
325.572\end{array}$ & $\begin{array}{r}11.582 \\
0.140\end{array}$ & $\begin{array}{l}691.934 \\
691.934\end{array}$ & $\begin{array}{l}1.845 \\
2.141\end{array}$ & $\begin{array}{l}0.003 \\
0.243\end{array}$ \\
\hline$\frac{1}{2}$ & $\begin{array}{l}17 \\
17\end{array}$ & $\begin{array}{l}325.572 \\
325.572\end{array}$ & $\begin{array}{l}0.140 \\
0.140\end{array}$ & $\begin{array}{r}1829.284 \\
114.564\end{array}$ & $\begin{array}{l}5.634 \\
0.367\end{array}$ & $\begin{array}{l}0.721 \\
0.000\end{array}$ \\
\hline 1 & 18 & 0.000 & 0.000 & 0.000 & 0.000 & -1 \\
\hline $\begin{array}{l}1 \\
2\end{array}$ & $\begin{array}{l}19 \\
19\end{array}$ & $\begin{array}{l}0.000 \\
0.000\end{array}$ & $\begin{array}{l}0.000 \\
0.000\end{array}$ & $\begin{array}{l}0.000 \\
0.000\end{array}$ & $\begin{array}{l}0.000 \\
0.000\end{array}$ & $\begin{array}{l}-I \\
-I\end{array}$ \\
\hline 1 & 20 & 0.000 & 0.000 & 0.000 & 0.000 & -1 \\
\hline $\begin{array}{l}1 \\
2 \\
3\end{array}$ & $\begin{array}{l}21 \\
21 \\
21\end{array}$ & $\begin{array}{r}1916.341 \\
476.669 \\
354.268\end{array}$ & $\begin{array}{l}0.873 \\
0.873 \\
0.873\end{array}$ & $\begin{array}{r}2073.003 \\
228.681 \\
71.877\end{array}$ & $\begin{array}{l}2.421 \\
0.639 \\
0.258\end{array}$ & $\begin{array}{l}5.000 \\
5.000 \\
5.000\end{array}$ \\
\hline $\begin{array}{l}1 \\
2\end{array}$ & $\begin{array}{l}22 \\
22\end{array}$ & $\begin{array}{l}2324.444 \\
2012.498\end{array}$ & $\begin{array}{l}0.873 \\
0.873\end{array}$ & $\begin{array}{l}2595.813 \\
2196.187\end{array}$ & $\begin{array}{l}2.668 \\
2.484\end{array}$ & $\begin{array}{l}5.000 \\
5.000\end{array}$ \\
\hline $\begin{array}{l}1 \\
2\end{array}$ & $\begin{array}{l}23 \\
23\end{array}$ & $\begin{array}{l}2324.444 \\
1832.732\end{array}$ & $\begin{array}{l}0.873 \\
0.873\end{array}$ & $\begin{array}{l}2595.813 \\
1965.895\end{array}$ & $\begin{array}{l}2.668 \\
2.364\end{array}$ & $\begin{array}{l}5.000 \\
5.000\end{array}$ \\
\hline
\end{tabular}


Table A26

STATE POINTS FOR THE COAL-FIRED TWO-STAGE REGENERATION, SINGLE REHEAT POWER CYCLE

\begin{tabular}{|c|c|c|c|c|c|c|}
\hline $\mathbf{K}$ & $\mathbf{L}$ & $\stackrel{\mathrm{T}}{\text { (DEG F) }}$ & $\underset{\text { (PSIA) }}{P}$ & $\begin{array}{c}\mathrm{H} \\
(\mathrm{BTU} / \mathrm{LB})\end{array}$ & $\begin{array}{c}\mathbf{S} \\
(\mathrm{BTU} / \mathrm{F}-\mathrm{LB})\end{array}$ & $\mathbf{Q}$ \\
\hline $\begin{array}{l}1 \\
2\end{array}$ & $\begin{array}{l}1 \\
1\end{array}$ & $\begin{array}{r}93.999 \\
404.312\end{array}$ & $\begin{array}{l}12.662 \\
12.662\end{array}$ & $\begin{array}{r}49.078 \\
204.234\end{array}$ & $\begin{array}{l}0.106 \\
0.745\end{array}$ & $\begin{array}{r}5.000 \\
-2.000\end{array}$ \\
\hline $\begin{array}{l}1 \\
2\end{array}$ & $\begin{array}{l}2 \\
2\end{array}$ & $\begin{array}{r}93.999 \\
404.312\end{array}$ & $\begin{array}{l}12.662 \\
12.662\end{array}$ & $\begin{array}{r}49.078 \\
123.471\end{array}$ & $\begin{array}{l}0.106 \\
0.213\end{array}$ & $\begin{array}{l}5.000 \\
5.000\end{array}$ \\
\hline 1 & 3 & 3724.312 & 12.662 & 1161.290 & 0.727 & 5.000 \\
\hline $\begin{array}{r}1 \\
2 \\
3 \\
4 \\
5 \\
6 \\
7 \\
8 \\
9 \\
10\end{array}$ & $\begin{array}{l}4 \\
4 \\
4 \\
4 \\
4 \\
4 \\
4 \\
4 \\
4 \\
4\end{array}$ & $\begin{array}{r}126.342 \\
127.162 \\
384.287 \\
384.287 \\
392.827 \\
392.827 \\
392.832 \\
776.165 \\
1000.112 \\
844.693\end{array}$ & $\begin{array}{r}2.031 \\
220.512 \\
206.009 \\
206.009 \\
2357.006 \\
2357.006 \\
2357.006 \\
2255.479 \\
2211.968 \\
1272.940\end{array}$ & $\begin{array}{r}94.269 \\
95.088 \\
358.220 \\
358.220 \\
367.394 \\
367.394 \\
367.400 \\
1297.879 \\
1467.871 \\
1404.129\end{array}$ & $\begin{array}{l}0.177 \\
0.178 \\
0.549 \\
0.549 \\
0.551 \\
0.551 \\
0.551 \\
1.418 \\
1.547 \\
1.556\end{array}$ & $\begin{array}{r}0.000 \\
-1.000 \\
0.000 \\
0.000 \\
-1.000 \\
-1.000 \\
-1.000 \\
2.000 \\
2.000 \\
2.000\end{array}$ \\
\hline $\begin{array}{l}1 \\
2 \\
3\end{array}$ & $\begin{array}{l}5 \\
5 \\
5\end{array}$ & $\begin{array}{l}844.693 \\
829.118 \\
740.088\end{array}$ & $\begin{array}{r}1272.940 \\
1258.436 \\
182.490\end{array}$ & $\begin{array}{l}1404.129 \\
1395.012 \\
1395.012\end{array}$ & $\begin{array}{l}1.556 \\
1.550 \\
1.753\end{array}$ & $\begin{array}{l}2.000 \\
2.000 \\
2.000\end{array}$ \\
\hline $\begin{array}{l}1 \\
2 \\
3\end{array}$ & $\begin{array}{l}6 \\
6 \\
6\end{array}$ & $\begin{array}{r}844.693 \\
1000.112 \\
547.574\end{array}$ & $\begin{array}{r}1272.940 \\
1243.932 \\
182.490\end{array}$ & $\begin{array}{l}1404.129 \\
1497.964 \\
1296.099\end{array}$ & $\begin{array}{l}1.556 \\
1.626 \\
1.663\end{array}$ & $\begin{array}{l}2.000 \\
2.000 \\
2.000\end{array}$ \\
\hline $\begin{array}{l}1 \\
2\end{array}$ & $\begin{array}{l}7 \\
7\end{array}$ & $\begin{array}{l}547.574 \\
126.342\end{array}$ & $\begin{array}{r}182.490 \\
2.031\end{array}$ & $\begin{array}{l}1296.099 \\
1017.999\end{array}$ & $\begin{array}{l}1.663 \\
1.753\end{array}$ & $\begin{array}{l}2.000 \\
0.904\end{array}$ \\
\hline 1 & 8 & 547.574 & 182.490 & 1296.099 & 1.663 & 2.000 \\
\hline 1 & 9 & 548.039 & 182.490 & 1296.344 & 1.663 & 2.000 \\
\hline 1 & 10 & -459.688 & 1000.762 & 45.003 & 0.089 & $\therefore-1$ \\
\hline $\begin{array}{l}1 \\
2 \\
3 \\
4\end{array}$ & $\begin{array}{l}11 \\
11 \\
11 \\
11\end{array}$ & $\begin{array}{r}82.706 \\
82.857 \\
120.917 \\
82.706\end{array}$ & $\begin{array}{l}12.662 \\
53.664 \\
53.664 \\
12.662\end{array}$ & $\begin{array}{l}50.720 \\
50.871 \\
88.853 \\
50.720\end{array}$ & $\begin{array}{l}0.100 \\
0.100 \\
0.168 \\
0.100\end{array}$ & $\begin{array}{l}-1.000 \\
-1.000 \\
-1.000 \\
-1.000\end{array}$ \\
\hline $\begin{array}{l}1 \\
2\end{array}$ & $\begin{array}{l}12 \\
12\end{array}$ & $\begin{array}{r}93.999 \\
100.002\end{array}$ & $\begin{array}{l}12.662 \\
12.662\end{array}$ & $\begin{array}{r}58.375 \\
103.922\end{array}$ & $\begin{array}{l}0.414 \\
0.109\end{array}$ & $\begin{array}{l}5.000 \\
5.000\end{array}$ \\
\hline 1 & 13 & 80.001 & 12.662 & 48.018 & 0.095 & -1.000 \\
\hline$\frac{1}{2}$ & $\begin{array}{l}14 \\
14\end{array}$ & $\begin{array}{l}548.039 \\
545.650\end{array}$ & $\begin{array}{l}182.490 \\
167.986\end{array}$ & $\begin{array}{l}1296.344 \\
1296.344\end{array}$ & $\begin{array}{l}1.663 \\
1.672\end{array}$ & $\begin{array}{l}2.000 \\
2.000\end{array}$ \\
\hline $\begin{array}{l}1 \\
2\end{array}$ & $\begin{array}{l}15 \\
15\end{array}$ & $\begin{array}{l}548.039 \\
136.235\end{array}$ & $\begin{array}{l}182.490 \\
167.986\end{array}$ & $\begin{array}{r}1296.344 \\
104.148\end{array}$ & $\begin{array}{l}1.663 \\
0.193\end{array}$ & $\begin{array}{r}2.000 \\
-1.000\end{array}$ \\
\hline $\begin{array}{l}1 \\
2\end{array}$ & $\begin{array}{l}16 \\
16\end{array}$ & $\begin{array}{l}367.414 \\
126.342\end{array}$ & $\begin{array}{r}167.986 \\
2.031\end{array}$ & $\begin{array}{l}342.558 \\
342.558\end{array}$ & $\begin{array}{l}0.530 \\
0.601\end{array}$ & $\begin{array}{l}0.003 \\
0.243\end{array}$ \\
\hline $\begin{array}{l}1 \\
2\end{array}$ & $\begin{array}{l}17 \\
17\end{array}$ & $\begin{array}{l}126.342 \\
126.342\end{array}$ & $\begin{array}{l}2.031 \\
2.031\end{array}$ & $\begin{array}{r}831.657 \\
94.269\end{array}$ & $\begin{array}{l}1.435 \\
0.177\end{array}$ & $\begin{array}{l}0.721 \\
0.000\end{array}$ \\
\hline 1 & 18 & -459.688 & 0.000 & 45.003 & 0.089 & $-I$ \\
\hline$\frac{1}{2}$ & $\begin{array}{l}19 \\
19\end{array}$ & $\begin{array}{l}-459.688 \\
-459.688\end{array}$ & $\begin{array}{l}0.000 \\
0.000\end{array}$ & $\begin{array}{l}45.003 \\
45.003\end{array}$ & $\begin{array}{l}0.089 \\
0.089\end{array}$ & $\begin{array}{l}-1 \\
-1\end{array}$ \\
\hline 1 & 20 & -459.688 & 0.000 & 45.003 & 0.089 & $-I$ \\
\hline $\begin{array}{l}1 \\
2 \\
3\end{array}$ & $\begin{array}{l}21 \\
21 \\
21\end{array}$ & $\begin{array}{r}2989.725 \\
398.316 \\
177.995\end{array}$ & $\begin{array}{l}12.662 \\
12.662 \\
12.662\end{array}$ & $\begin{array}{r}936.464 \\
143.343 \\
75.913\end{array}$ & $\begin{array}{l}0.668 \\
0.242 \\
0.151\end{array}$ & $\begin{array}{l}5.000 \\
5.000 \\
5.000\end{array}$ \\
\hline $\begin{array}{l}1 \\
2\end{array}$ & $\begin{array}{l}22 \\
22\end{array}$ & $\begin{array}{l}3724.312 \\
3162.808\end{array}$ & $\begin{array}{l}12.662 \\
12.662\end{array}$ & $\begin{array}{r}1161.290 \\
989.437\end{array}$ & $\begin{array}{l}0.727 \\
0.683\end{array}$ & $\begin{array}{l}5.000 \\
5.000\end{array}$ \\
\hline $\begin{array}{l}1 \\
2\end{array}$ & $\begin{array}{l}23 \\
23\end{array}$ & $\begin{array}{l}3724.312 \\
2839.230\end{array}$ & $\begin{array}{l}12.662 \\
12.662\end{array}$ & $\begin{array}{r}1161.290 \\
890.404\end{array}$ & $\begin{array}{l}0.727 \\
0.654\end{array}$ & $\begin{array}{l}5.000 \\
5.000\end{array}$ \\
\hline
\end{tabular}




\section{A. 37}

Table A27

STREAM FLOW RATES FOR THE FOSSIL-FIRED CYCLE

\begin{tabular}{|c|c|c|c|c|}
\hline $\mathbf{L}$ & $\begin{array}{c}G \\
(K G / S E C)\end{array}$ & $\begin{array}{c}G \\
(\mathrm{KLB} / \mathrm{HR})\end{array}$ & $\begin{array}{l}\text { F1uid } \\
\text { Number }\end{array}$ & $\begin{array}{c}\text { Fluid } \\
\text { Description }\end{array}$ \\
\hline 1 & 5.04034 & 40.00337 & 7 & Coal \\
\hline 2 & 48.81850 & 387.45489 & 7 & Atmospheric Air \\
\hline 3 & 53.85885 & 427.45826 & 6 & Flue Gases \\
\hline 4 & 45.90813 & 364.35631 & 1 & Water \\
\hline 5 & 0.03133 & 0.24869 & 1 & Water \\
\hline 6 & 45.87680 & 364.10762 & 1 & Water \\
\hline 7 & 33.24290 & 263.83690 & 1 & Water \\
\hline 8 & 12.63390 & 100.27072 & 1 & Water \\
\hline 9 & 12.66524 & 100.51941 & 1 & Water \\
\hline 10 & 0.00000 & 0.00000 & 1 & Water \\
\hline 11 & 891.25172 & 7073.54402 & 1 & Water \\
\hline 12 & 749.03965 & 5944.85803 & 7 & Atmospheric Air \\
\hline 13 & 31.15983 & 247.30432 & 1 & Water \\
\hline 14 & 2.53273 & 20.10140 & 1 & Water \\
\hline 15 & 10.13250 & 80.41801 & 1 & Water \\
\hline 16 & 12.66524 & 100.51941 & 1 & Water \\
\hline 17 & 45.90813 & 364.35631 & 1 & Water \\
\hline 18 & 0.00000 & 0.00000 & 1 & Water \\
\hline 19 & 0.00000 & 0.00000 & 1 & Water \\
\hline 20 & 0.00000 & 0.00000 & 1 & Water \\
\hline 21 & 53.85885 & 427.45826 & 6 & Flue Gases \\
\hline 22 & 25.04955 & 198.80923 & 6 & Flue Gases \\
\hline 23 & 28.80930 & 228.64903 & 6 & Flue Gases \\
\hline
\end{tabular}




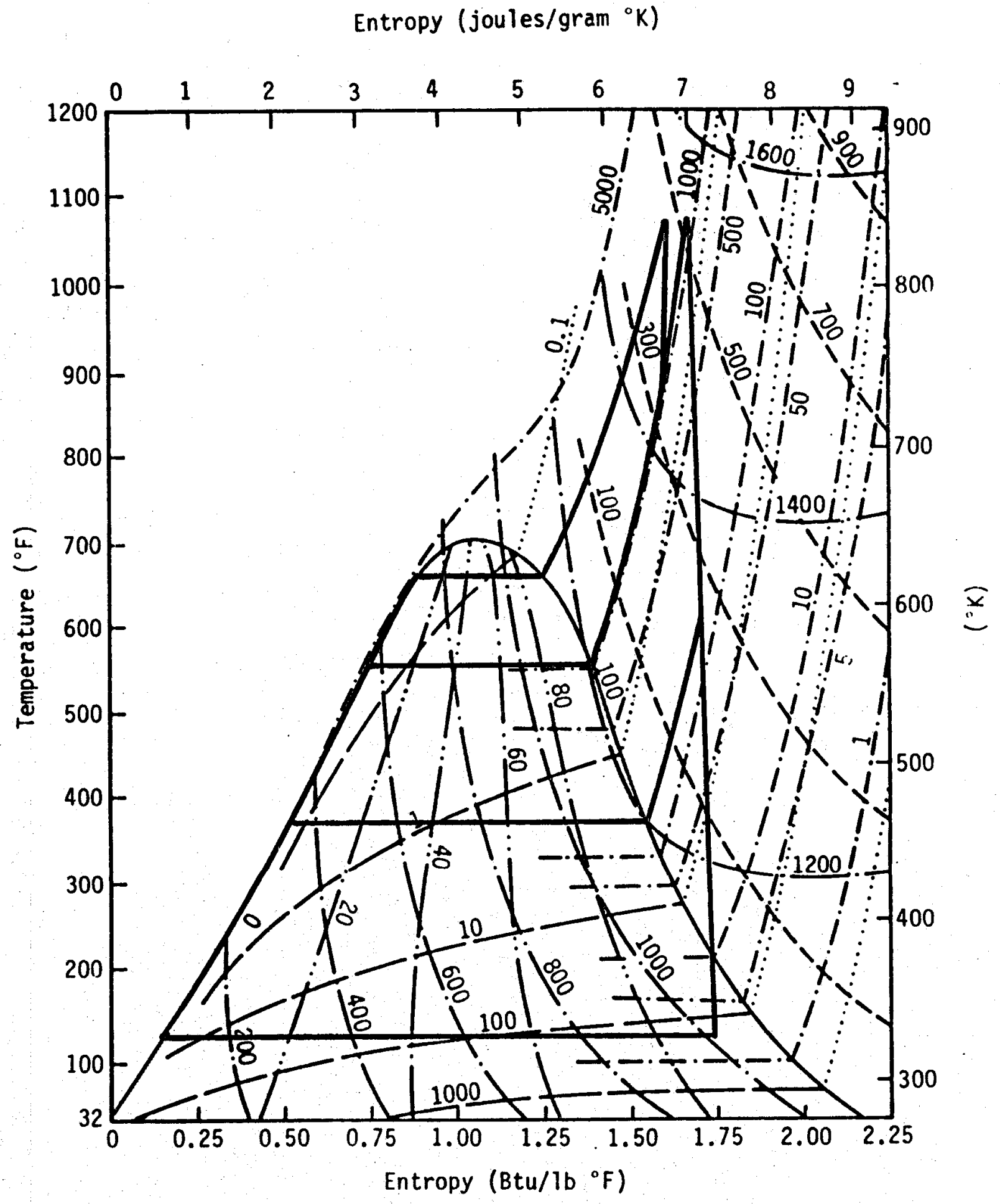

Fig. A8--Temperature-entropy diagram for the fossil fuelfired cycle 
Appendix B

OPTIMIZATION ROUTINE CHARACTERISTICS

This section provides a description of algorithms and subroutines used for cost-optimization of a fossil/geothermal hybrid power plant. It detalls the capabilities, limitations, and specific assumptions inherent In PSR's GEOTHMF program and in the model plants this code generates. GEOTHMF is a modified and extended version of a purely geothermal code, GEOTHM, written at the Lawrence Berkeley Laboratory (LBL).

\section{Cost Function}

Considerable program modifications were made in the costing routines of GEOTHM to satisfy study needs for analyzing hybrid power-plant cycles. The cost functions in GEOTHMF used for the power-plant optimization calculations can be divided into three categories: 1) plant-component capital costs; 2) site-specific costs; 3) time-dependent cost factors. Each category is discussed in detall below.

Plant-component capital costs include

- Land and land rights;

o Structures and improvements;

- Steam generator;

- Turbine generator;

- Feedwater heat exchangers;

- Station electric and miscellaneous equipment, tools, etc.;

- Industrial waste;

o Auxiliary boller, steam, fuel, mechanical, and I\&C systems;

- Condenser;

- Cooling tower;

- Construction, labor/management.

For the above cost considerations, cost values were determined from efther 1) functional relationships that can be adjusted for economies of scale and are dependent on cycle thermodynamic parameters or 2) specific values, where average or representative quantities were assumed. 
Site-specific costs in the GEOTHIF Program Include

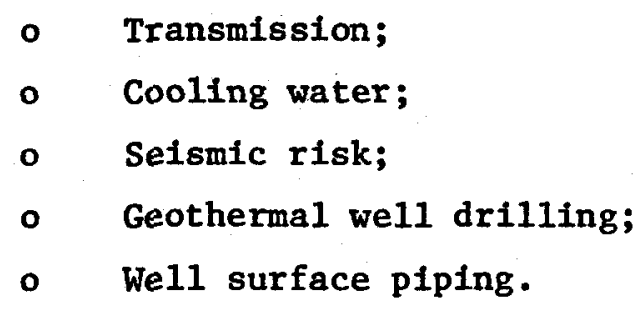

Since power costs are expressed in "1976 dollars," not current dollars, annual average cost factors were developed (see below) and added to the program to multiply capital costs to obtain the average annual cost of producing power.

\section{Geothermal-We11 Resource Mode1}

The geothermal-well resource model in GEOTHMF (detalled below) is based on exponential depletion of the well resource. That is, well depletion is assumed to follow the relationship

$$
\dot{\mathrm{m}}(t)=\dot{\mathrm{m}} \mathrm{e}^{-\lambda t},
$$

where $\dot{\mathrm{n}}$ is the Initial maximum flow rate of a we11, $\lambda=0.693 / \mathrm{T}_{1 / 2}$, and $T_{1 / 2}$ is the well half-1ife $(10 \mathrm{yr})$ assumed for this study. Given $\dot{M}$ as the initial power-plant flow rate demand, the number of wells required is 


$$
\frac{\dot{\mathrm{M}}}{\dot{\mathrm{m}}}=\mathrm{n}+\gamma, \quad 0 \leq \gamma<1 \text {, }
$$

where

$$
\begin{aligned}
& \mathbf{n}=\text { integer number of wells, } \\
& \gamma=\text { partial well requirement }
\end{aligned}
$$

Note that, although only an integer number of wells is drilled, the plant's flow requirements are not restricted to integer flow amounts.

The model further assumes that the plant-flow-rate demand, $\dot{M}$, is maintained, being supplied by pumping the resource from the excess well portion $(1-\gamma)$ at the maximum required rate until source depletion, at which time,

$$
t_{1}=\frac{1-\gamma}{\lambda(n+\gamma)}
$$

a first new well is required. Subsequent new wells may be required to maintain flow, $\dot{M}$, at intervals

$$
\Delta t=\frac{1}{\lambda(n+\gamma)}
$$

when $t_{1}<N$ (1ife of plant). According to the model, the number of wells, $N_{W}$, required over the life of the plant, $N(y r)$, is as follows:

$$
N_{W}= \begin{cases}(n+1), & t_{1} \geq N \\ (n+1)+I\left(\frac{N-t_{1}}{\Delta t}\right), & t_{1}<N\end{cases}
$$

where $I\left[\left(N-t_{1}\right) / \Delta t\right]$ designates rounding up to the next highest integer. The average annual number of resource wells is $N_{W} / N$; including reinjection wells, the average annual number of wells, $\overline{\mathrm{N}}_{W}$, is equal to 1.5 $\left(\mathrm{N}_{W} / \mathrm{N}\right)$. Multiplying $\overline{\mathrm{N}}_{W}$ by the cost per well and the pipe factor gives the annual average cost of wells. 


\section{Cooling Tower}

The cooling-tower computational routine was revised in formulating the output parameters that are desired for this study. This revision involves a consistent matching of equation-of-state value for water in GEOTHM, with an analytical representation of Psychrometric Chart parameters.

\section{Output}

Cost output includes a listing of capital costs and time-dependent costs for cost-optimized power plants. Total plant capital costs are given in terms of $\$ / \mathrm{kW}$; and cost of power, in terms of $\mathrm{mills} / \mathrm{kWh}$.

Cycle output modifications to the GEOTHM Program include dual output of the thermodynamic properties in both SI and English units; revision of the overall plant-cycle energy balance and efficiency statements; and cooling-tower parameters.

For a given net power-plant electrical-output rating, $P(M W)$, other quantities, such as the turbine shaft power, are calculated as indicated by the relationships shown in FIg. B.1. All cycle process pumps are assumed to be directly coupled to the mechanical output of the turbines. In actuality, large modern power plants use turbine extraction steam to drive special turbines to supply pump power; however, because relative power-plant comparisons are of primary interest, we do not attempt detailed simulation of steam extraction for auxiliary equipment for the optimization calculations. Calculated power-plant efficiencies in GEOTHMF are as follows:

$$
\begin{aligned}
& \text { Net plant efficiency }=\frac{P}{\dot{Q}_{b}+\dot{Q}_{g}} ; \\
& \text { Fraction of geothermal contribution }=\frac{\dot{Q}_{g}}{\dot{Q}_{b}+\dot{Q}_{g}} ; \\
& \text { Geothermal utilization efficiency }=\frac{\dot{Q}_{g}}{\dot{Q}_{g, i n}} ; \\
& \text { Geothermal conversion function }=\left(\frac{P}{\dot{Q}_{b}+\dot{Q}_{g}}\right)\left(\frac{\dot{Q}_{g}}{\dot{Q}_{g, \text { In }}}\right)
\end{aligned}
$$




\section{Optimization Routine}

Hybrid-cycle power-plant optimization calculations are performed with the GEOTHMF Program, using the LBL 7600 machine. Typical run times require about $45 \mathrm{sec}$ to perform from about 500 to 1000 consecutive cycle iterations for, typically, 9 independently varying optimizable parameters.

\section{Cycle Configuration}

Cycle components are linked together, based on the GEOTHMF input procedure, where a minimum Input data-set is required to achieve a valid initlal thermodynamic-cycle balance. The data-set includes primarily temperatures, pressures, and a reference working-fluid flow rate.

Basic input assumptions for the components are as follows:

\section{Efficiencies}

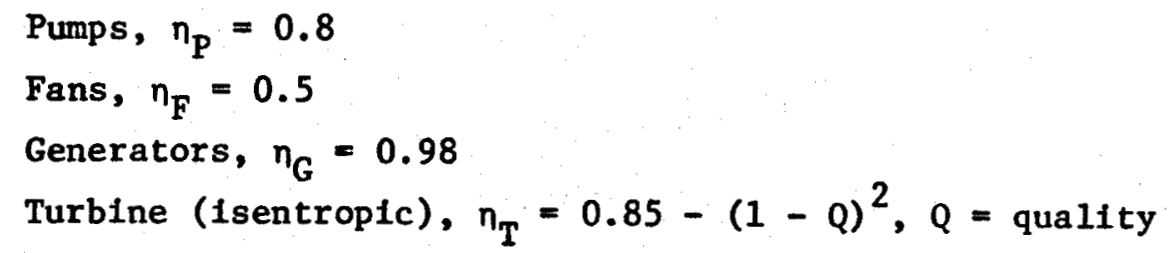

\section{Optimizable Parameters}

In the GEOTHMF Program, any thermodynamic parameter (temperature, pressure, pinch point, etc.) may be specified as an optimizable parameter. Selection of optimizable parameters is accomplished by examining the cycle configuration and identifying those parameters that can independently affect the cycle thermodynamics and plant costs. For the GEOTHMF calculations, the optimizable parameters are allowed to vary between specified maximum and minimum input values. The fact that they are allowed to vary results in altering all those cycle parameters dependent on any single variation.

\section{Calculational Procedure}

The calculationa1 procedure of GEOTHMF for determining an optimum plant design is based on finding a unique set, $x^{*}$, of cycle parameters 
such that a defined objective function, $f\left[x_{k}\right]$, is a minimum; 1.e., $f\left[x^{*}\right]=\min \left\{f\left[x_{k}\right]\right\}$.

The required input consists of data for

- Energy source characteristics for the steam generator;

- Net power-plant requirement;

- Thermodynamic-cycle definition;

- Thermodynamic efficiency factors for the cycle components;

- Inftial cycle-state parameters;

- Definition of optimizable parameters;

- Definition of the objective function;

- Cost data;

- Appropriate constraint- and penalty-function data for the cycle components and state parameters.

The cycle can then be characterized by an overall parameter set, $x_{k}=\left\{x_{1}, x_{2}, \ldots, x_{N}\right\}$, where $x_{1}=$ cycle parameter; e.g., temperature, pressure, pinch-point $\Delta \mathrm{T}$, heat-exchanger $\mathrm{U}$-factor. For the plantoptimization calculations, a certain number, $N^{\prime}$, of the $x_{1}$ parameters are designated as optimizable parameters, $x_{1}^{\prime}$, where normally $N^{\prime} \ll N$. The Initial set of parameters, $x_{0}$, contains the starting values for the optimization procedure. They must be specified so as to result in the calculation of a reasonable, although not optimum, thermodynamic cycle. Note that there is optionally a passive-mode cycle calculation where the optimization routine is bypassed. For that option, the user designs the plant; otherwise, the optimization routine designs the plant in which GEOTHMF is used as a function generator.

In addition to $x_{k}$, program output consists of a set of performance factors, $F=\left\{f_{1}\left[X_{k}\right], f_{2}\left[X_{k}\right], \ldots, f_{M}\left[X_{k}\right]\right\}$, where $f_{j}\left[X_{k}\right]$ is, for example, cost of power (mills $/ \mathrm{kWh})$, plant capital cost $(\$ / \mathrm{kW})$, net cycle efficiency $(\%)$, geothermal-resource contribution to power output (\%). For these calculations, the inverse of power generated (MW) is defined as the objective function, $f\left[x_{k}\right]$, to be minimized.

Initially, an objective function, $f\left[x_{0}\right]$, is calculated, using the initial thermodynamic cycle parameters, $x_{0}$. In addition, a set of partial derivatives, 


$$
f^{\prime}\left[x_{0}\right]=\left\{\frac{\partial F\left[x_{0}\right]}{\partial x_{1}^{\prime}}, \frac{\partial F\left[x_{0}\right]}{\partial x_{2}^{\prime}}, \ldots, \frac{\partial F\left[x_{0}\right]}{\partial x_{N}^{\prime}}\right\}
$$

is calculated, using input step values $\left( \pm x_{j}^{\prime}\right)$ for the optimizable parameters. The optimization routine, MINUIT, uses the $\mathrm{f}^{\prime}\left[\mathrm{X}_{0}\right]$ values to commence the cyclic optimization procedure. MINUIT employs two separate subroutines, SIMPLEX and MIGRAD, to develop parameter sets, $X_{k}$, each of which is based on a different approach in searching for the global minimum of $f\left[x_{k}\right]$. The thermodynamic-cycle calculations supply $x_{k}, f\left[x_{k}\right]$, and $f^{\prime}\left[\mathrm{x}_{k}\right]$. The optimization calculational procedure continues as long as the convergence criteria, $\varepsilon$, is not satisfied. Parameter set improvements, $x_{k+1}$, are developed by MINUIT, and subsequent objective functions are determined. When the convergence criteria are satisfied, GEOTHMF performs a final calculation of the power-plant cycle thermodynamics, employing the current optimizable parameter values, $\left(x_{1}^{\prime}, x_{2}^{\prime}, \ldots\right.$, $x_{N}^{\prime}$ ), to yield a set of all cycle parameters, $x^{*}$, and the set of plantperformance factors, $F^{*}$, one of which is the minimum value of the designated objective function, $f\left[x^{*}\right]=\min f\left[x_{k}\right]$, the inverse of power developed (MW).

The optimization calculations for this study, performed in the manner described above, result in a partially constrained minimum, insofar as penalty (cost) functions are imposed for unrealistic parameter varlations. Imposing both parameter constraints and penalty functions is the means whereby the optimization procedure is guided within the "hard" and "soft" boundaries, respectlvely, to resemble, somewhat, a modern power-plant design.

\section{Costs}

The foilowing discussions detall the specific cost components used in the GEOTHMF Program for performing the power-plant-cycle cost-optimization calculations. Power-plant costing, as discussed below, is divided into 1) plant-component capital costs (Including construction labor/ management); 2) site-specific costs; and 3) t1me-dependent cost factors. Plant-cost values used in the optimization calculations are based on a combination of various cost algorithms and specific point values. In 
general, the various plant, site-spectfic, and time-dependent costing algorithms are specifically developed and added to the GEOTHM Program; however, where existing cost algorithms in the GEOTHM are applicable, they are used either directly, or are normalized to be consistent with the rest of the code.

Primary emphasis in developing the plant costs is placed on establishing costs in a relative rather than an absolute sense. The cost relationships and values, therefore, omit a detailed breakdown normally present in precise power-plant design specifications. Accordingly, many of the costs given below represent aggregate values of various plant systems and components.

\section{Plant-Component Capital Costs}

Plant capital-cost components, given below, include cost relationships and values that take into account economies of scale based on plant size parameters, such as overall heat-transfer rates to the workIng fluid, $\dot{Q}$, and power-plant rating, $P R(M W)$.

The following capital costs (In millions of dollars) are based on a nominal plant with a net electrical output rating of $P R=750 \mathrm{MW}$ :

\begin{tabular}{l|c}
\hline \multicolumn{1}{c|}{ Capita1 Component } & Cost, Million $\$$ \\
\hline Land and land rights & $0.9\left(\frac{\mathrm{PR}}{750}\right)^{0.5}$ \\
\hline & $\mathrm{SF} \times 57\left(\frac{\mathrm{PR}}{750}\right)^{0.5}$ \\
\hline \begin{tabular}{l} 
Structures and improvements \\
$\begin{array}{l}\text { Station electric, miscellaneous power- } \\
\text { plant and accessory electrical } \\
\text { equipment and tools }\end{array}$ \\
\hline $\begin{array}{l}\text { Mechanical equipment; instrumentation; } \\
\text { and controls }\end{array}$
\end{tabular}$\quad 15.3\left(\frac{\mathrm{PR}}{750}\right)^{0.9}$ \\
\hline
\end{tabular}

Note: SF is a cost multiplying factor for seismic considerations. 
The following are plant capital-cost relationships based on scaling the net heat-transfer rate to the working fluld, $\dot{Q}(M W)$, assumed to be 1984 MW:

\begin{tabular}{l|c}
\multicolumn{1}{c|}{ Capital Component } & Cost, Million $\$$ \\
\hline Industrial waste & $1.2\left(\frac{\dot{Q}}{1984}\right)^{0.75}$ \\
\hline & $5+0.05 \dot{Q}$ \\
Steam generation & $5+0.12 \dot{Q}$ \\
\hline
\end{tabular}

\section{Turbine-Generator}

Turbine-generator costs used in the optimization calculations are based on a cost algorithm developed from General Electric Company price data for large steam turbine-generator units. The costing algorithms take into account economies of scale for turbine output rating, and cost variations for exhaust pressure and turbine inlet temperature, and pressure for the high-pressure (HP) and intermediate-pressure (IP) turbines; no correction is made for make-up, which implicitly assumes a value of 3 percent. Accordingly, the turbine cost is given as

$$
\mathrm{C}_{\mathrm{T}}=\mathrm{C}_{\mathrm{T}, 0}+10^{-3}\left(\mathrm{C}_{\mathrm{T}, \mathrm{T}}+\mathrm{C}_{\mathrm{T}, \mathrm{P}}\right)(\text { M111ion } \$) \text {, }
$$

where $C_{T, 0}$ is the basic turbine cost, given as

$$
\mathrm{C}_{\mathrm{T}, 0}=\left\{\begin{array}{ll}
28.2\left(\frac{\mathrm{ETR}}{650}\right)^{0.739}, & 0.5 \leq \mathrm{P}_{\mathrm{ex}} \leq 4.5 \\
28.9\left(\frac{\mathrm{ETR}}{650}\right)^{0.739}, & 4.5<\mathrm{P}_{\mathrm{ex}} \leq 15
\end{array} ;\right.
$$

and

$$
\begin{aligned}
P_{\text {ex }} & =\text { turbine exhaust pressure, inches of } \mathrm{Hg} \\
\text { ETR } & =\text { equivalent turbine rating, } M W \\
& =\operatorname{STR}(1-x)
\end{aligned}
$$


STR = shaft turbine rating, MW;

$x=a$ correction factor determined as follows:

$$
\begin{array}{lll}
0.5 \leq \mathrm{P}_{\text {ex }} \leq 1 & , & \mathrm{x}=0.025 \\
0.5<\mathrm{P}_{\mathrm{ex}} \leq 3.5 & , & \mathrm{x}=0.025+0.01\left(1-\mathrm{P}_{\mathrm{ex}}\right) \\
3.5<\mathrm{P}_{\mathrm{ex}} \leq 4.5 & , & \mathrm{x}=0.02\left(3.5-\mathrm{P}_{\mathrm{ex}}\right) \\
4.5<\mathrm{P}_{\mathrm{ex}} \leq 5.0 & , & \mathrm{x}=0.03398\left(\mathrm{P}_{\mathrm{ex}}-4.5\right)-0.003116 \\
5.0<\mathrm{P}_{\text {ex }} \leq 15 & , & \mathrm{x}=0.01\left(8-\mathrm{P}_{\mathrm{ex}}\right)
\end{array}
$$

The cost correction (reduction or add-on) for turbine inlet temperature variations for HP and IP turbines is given as

$$
\mathrm{C}_{\mathrm{T}, \mathrm{T}}=\mathrm{C}_{\mathrm{HP}}+\mathrm{C}_{\mathrm{IP}}
$$

where $C_{H P}$ and $C_{I P}$ are determined as follows:

\begin{tabular}{c|c|c}
\hline $\begin{array}{l}\text { HP Turbine Inlet } \\
\text { Temperature, }{ }^{\circ} \mathrm{F}\end{array}$ & ETR Range, MW & $\mathrm{C}_{\mathrm{HP}}$, Thousand $\$$ \\
\hline $901-950$ & $200 \leq$ ETR $\leq 700$ & $200(200-$ ETR $)-60$ \\
$951-1000$ & $200 \leq$ ETR $\leq 1100$ & 0 \\
$1001-1051$ & $200 \leq$ ETR $\leq 1100$ & $600($ ETR -200$)+180$ \\
\hline
\end{tabular}

\begin{tabular}{c|c|c}
\hline $\begin{array}{l}\text { IP Turbine Inlet } \\
\text { Temperature, }{ }^{\circ} \mathrm{F}\end{array}$ & ETR Range, MW & $\mathrm{C}_{\text {IP }}$, Thousand $\$$ \\
\hline $901-950$ & $200 \leq$ ETR $\leq 700$ & $200(200-$ ETR $)-60$ \\
$951-1000$ & $200 \leq$ ETR $\leq 1100$ & 0 \\
$1001-1025$ & $200 \leq$ ETR $\leq 500$ & 300 \\
& $500 \leq$ ETR $\leq 800$ & $200($ ETR -500$)+300$ \\
$1026-1050$ & $200 \leq$ ETR $\leq 500$ & 500 \\
& $500<$ ETR $\leq 800$ & $200($ ETR -500$)+500$ \\
\hline
\end{tabular}

The cost correction for HP turbine Inlet pressure, $C_{\mathrm{T}, \mathrm{P}}$, depends on the inlet pressure, $P_{1}$ (psig), and $\operatorname{ETR}(M W)$, as follows: 


\begin{tabular}{|c|c|c|}
\hline Pressure Range & ETR Range, MW & $\mathrm{C}_{\mathrm{T}, \mathrm{P}}$, Thousand $\$$ \\
\hline$P_{1}<1750$ & $\begin{array}{l}\mathrm{ETR} \leq 300 \\
\mathrm{ETR}>300\end{array}$ & $\begin{array}{l}1200(\text { ETR }-300)+120 \\
3330(\text { ETR }-100)^{2}\end{array}$ \\
\hline $1750 \leq \mathrm{P}_{i}<2150$ & $\begin{array}{c}\text { ETR } \leq 300 \\
300<\text { ETR } \leq 400 \\
\text { ETR }>400\end{array}$ & $\begin{array}{c}0 \\
1200(\text { ETR }-400)+120 \\
3330(\text { ETR }-200)^{2}\end{array}$ \\
\hline $2150 \leq \mathrm{P}_{1}<2450$ & $\begin{aligned} \text { ETR } & \leq 300 \\
300 & <\text { ETR } \leq 400 \\
400 & <\text { ETR } \leq 500 \\
\text { ETR } & >500\end{aligned}$ & $\begin{array}{l}1200(300-\text { ETR }) \\
0 \\
1200(\text { ETR }-500)+1200 \\
3330(\text { ETR }-300)^{2}\end{array}$ \\
\hline $2450 \leq P_{1}<3050$ & $\begin{array}{c}\text { ETR } \leq 400 \\
400<\operatorname{ETR} \leq 500 \\
\text { ETR }>500\end{array}$ & $\begin{array}{c}1200(400-E T R) \\
0 \\
3330(E T R-400)^{2}\end{array}$ \\
\hline$P_{1} \geq 3050$ & $\begin{aligned} \text { ETR } & \leq 400 \\
400 & <\operatorname{ETR} \leq 500 \\
\text { ETR } & >500\end{aligned}$ & $\begin{array}{c}2100(400-\text { ETR })+120 \\
1200(500-\text { ETR }) \\
0\end{array}$ \\
\hline
\end{tabular}

Feedwater Heat Exchangers

The cost of feedwater heat exchangers is assumed to be a function of the pressure and the heat-transfer area. Based on estimated cost data for feedwater heaters, the cost-per-untit-area is approximated by the relationship

$$
C_{A}=10\left(\frac{P_{t}}{300}\right)^{0.282}\left(\$ / f t^{2}\right)
$$

where $P_{t}$ (psig) is the tube pressure. The cost of feedwater heaters for the power-plant optimization calculations is as follows:

$$
\left.C_{F W}=\left(70 \times 10^{-6}\right)\left(\frac{P_{t}}{300}\right)^{0.282} A \text { (Million } \$\right),
$$

where $A\left(\mathrm{ft}^{2}\right)$ is the heat-transfer area of the heat exchanger. 


\section{Condenser}

The condenser costing algorithm in GEOTHM is used. The algorithm considers turbine exhaust pressure, $1.4 \mathrm{psia}$, and cooling-tower inlet water pressure, $53.66 \mathrm{psi}$; for these values, condenser costs are estimated at the rate of $\$ 5.03 / \mathrm{ft}^{2}$.

\section{Cooling Tower}

Cooling-tower costs are based on the algorithm given in GEOTHM, normalized as follows:

$$
\mathrm{C}_{\mathrm{CT}}=\left(30.08 \times 10^{-6}\right) \times \mathrm{TU} \times \mathrm{SF} \quad(\text { Million } \$),
$$

where SF is a cost multiplying factor for seismic considerations and TU is the required number of tower units given as

$$
T U=R F \times G P M,
$$

where $R F$ is the rating factor, a function of the wet-bulb, range, and approach temperatures.

Pumps

Pump costs used are those in GEOTHM. The cost algorithm is as follows :

$$
C_{P}=\left(0.046+1.1786 \times 10^{-5} \times P_{M}\right) P_{P}^{Y} \quad(\text { Million } \$)
$$

where

$$
\begin{aligned}
Y & =0.917+2.239 \times 10^{-6} \times \mathrm{P}_{\mathrm{M}}, \\
\mathrm{P}_{\mathrm{P}} & =\text { power transferred to the working fluid (MW), } \\
P_{M} & =P_{1}-305.58 \text { (bar) } \\
P_{1} & =\text { inlet pressure (bar) }
\end{aligned}
$$

and

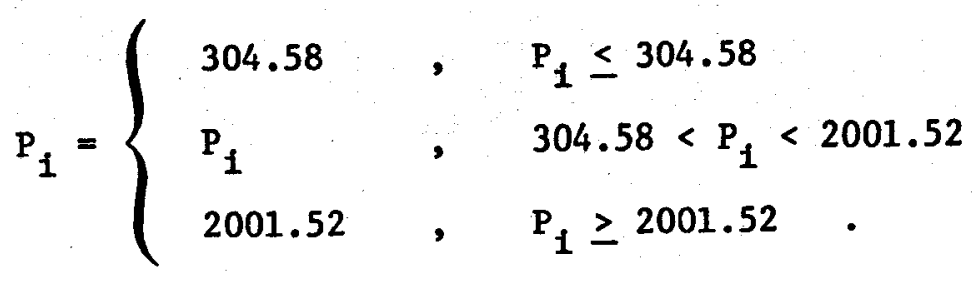




\section{We11 Drilling and Piping}

Well-drilling costs are based on cost information gathered by the City of Burbank for the Coso site. Wells are assumed to be drilled to depths of $5000 \mathrm{ft}$ to $6000 \mathrm{ft}$. In addition, it is assumed that one reinjection well is drilled for every two resource wells drilled, at the equivalent well-drilling cost per reinjection well. The assumed drilling costs per well at coso is $C_{W}=\$ 700,000$. The model for determining the total number of resource wells required is based on exponential source depletion with a half-life of 10 years.

The overall capital cost per well is based on a cost multiplying factor, $F_{p}$, which considers the additional cost of ground-level piping. This factor, based on the number of wells, $n$, is determined by the GEOTHM Program as tabulated below:

\begin{tabular}{c|c}
\hline Number of We11s, $n$ & $F_{p}$, Vapor-Dominated We11s \\
\hline $\mathbf{n} \leq 6$ & 1.15 \\
$6<n \leq 18$ & 1.23 \\
$18<\mathrm{n} \leq 36$ & 1.32 \\
$36<\mathrm{n} \leq 60$ & 1.42 \\
$60<\mathrm{n} \leq 90$ & 1.47 \\
$\mathrm{n}>90$ & 1.48 \\
\hline
\end{tabular}

The total cost of we11s is then

$$
\left.\mathrm{C}_{\mathrm{TW}}=\mathrm{nF}_{\mathrm{p}} \mathrm{C}_{\mathrm{W}} \times 10^{-6} \quad \text { (Mi11ion } \$\right)
$$

Construction Labor/Management

Indirect costs, Including those for construction facllities, equipment, and engineering and management services, generally fall between 25 percent and 29 percent of the physical-plant costs. A value of 28.67 percent is assumed.

Time-Dependent Costs

The cost of producing power is calculated in terms of "1976 dollars." Accordingly, the annual average plant costs take into account projected 
Inflation and bond interest given by the following terms (where the values in parentheses are those used in plant optimization calculations):

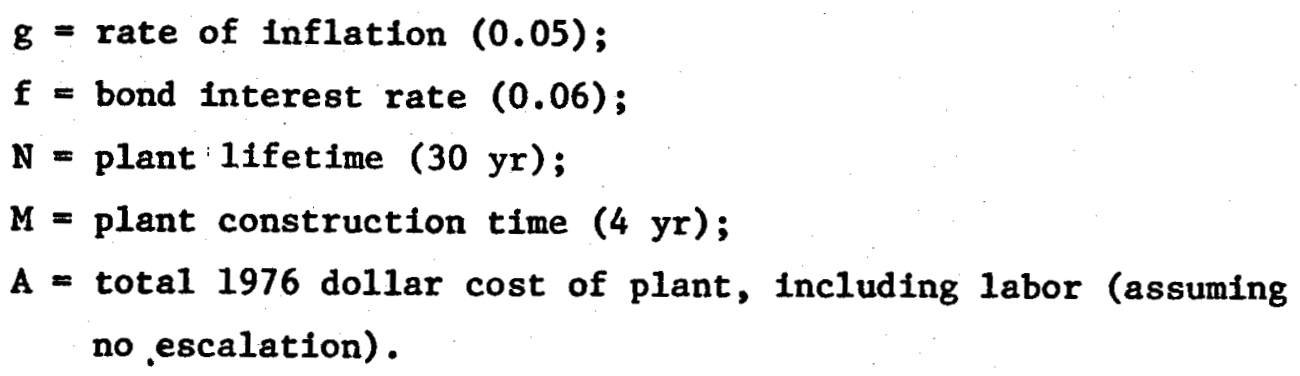

$$
C C F=\frac{1}{M}\left[\frac{(1+f)^{M}-(1+g)^{-M}}{\ln (1+f)+\ln (1+g)}\right]
$$

The true cost of the plant is then $A \times$ (CCF). The bond interest cost factor (BICF) is

$$
B I C F=\frac{f(1+f)^{N}}{(1+f)^{N}-1} \sum_{i=1}^{N} \frac{1}{(1+g)^{1+M}}
$$

Accordingly, the total value of all bonds repaid (in 1976 dollars) is $A \times$ (BICF). Bond redemption is estimated to begin at the end of the $(M+1)^{\text {th }}$ year and to continue at an accelerating rate until the end of the $(M+N)^{\text {th }}$ year.

The net capital factor (NCF) is the product (CCF) $\times$ (BICF). Thus, a plant with a 1976 dollar cost, A, is assumed to be constructed (straight1ine) over a period of $M$ years, Including bond indebtedness (straightline) over this period, so that at the end of the $M^{\text {th }}$ year, the plant is operational with a total accumulated dollar debt, $\mathrm{A}$ (CCF), including the bonds plus interest. The total cost (In 1976 dollars) of the plant is then Ax (NCF). Amortized over the operating 11fe of the plant, the average annual capital factor (AACF) is

$$
A A C F=\frac{1}{N} \times(N C F)
$$




\section{B. 16}

and the average annual capital cost (AACC) in 1976 dollars of redeeming the bonds is

$$
\mathrm{AACC}=\mathrm{A} \times(\mathrm{AACF})
$$

The $0 / M$ cost growth rate is assumed to be equivalent to the estimated inflation rate ( 5 percent per year). Therefore, plant and well $0 / \mathrm{M}$ costs are merely a flat percentage of the corresponding capital costs; the same growth-rate correspondence is also assumed for the cost of coolIng water and power transmission.

\section{Site-Specific Costs}

Site-specific costs--those for transmission, cooling water, geothermal wells and surface piping, and seismic considerations--can be included in the plant optimization calculations. Note that the costs of geothermal wells and surface piping are discussed above under "Plant-Component Capital Costs."

\section{Cooling Water}

The cost of cooling water, $\mathrm{C}_{\mathrm{cw}}(\mathrm{mills} / \mathrm{kWh})$, is based on a relationship of the form

$$
\begin{aligned}
C_{c w} & =3.6768 \times 10^{-7}\left(\frac{c_{s} \dot{M}_{w}}{P}+\frac{C_{T} \dot{M}_{w} d_{T}}{P}\right) \\
& +5.8055 \times 10^{-8} \frac{\dot{\mathrm{M}}_{w}}{\mathrm{P}}(\mathrm{m} 111 \mathrm{~s} / \mathrm{kWh})
\end{aligned}
$$

where

$$
\begin{aligned}
& C_{S}=\text { cost of water at the source }(\$ / \text { acre-ft }), \\
& C_{T}=\text { conveyance cost }(\$ / \text { acre-ft-mi), } \\
& \dot{M}_{W}=\text { power-plant cooling requirement }(1 \mathrm{~b} / \mathrm{hr}), \\
& d_{T}=\text { conveyance distance }(\mathrm{ml}), \\
& H=\text { power-plant elevation distance above water source }(\mathrm{ft})(\mathrm{H} \geq 0), \\
& P=\text { power-plant rating }(\mathrm{MW}) .
\end{aligned}
$$


For Coso, cooling water is assumed to be obtained from the Los Angeles Aqueduct. Accordingly, the following site-specific values are projected for the cost relationship above:

\begin{tabular}{c|c}
\hline$C_{S}(\$ /$ acre-ft $)$ & 100 \\
$C_{T}(\$ /$ acre-ft-mi) & 4.21 \\
$d_{T}(m i)$ & 10 \\
$H(f t)$ & 0 \\
\hline
\end{tabular}

\section{Se1smic Factor}

Seismic factors, SF, can be included to adjust for any additional costs incurred because of spectal construction required, and so that the plants could withstand any significant ground acceleration that might occur from maximum expected earthquakes. Detailed dynamic structural analysis, however, was not undertaken in arriving at seismic cost factors; instead, the factors were based on a review of the seismicity and maximum credible ground accelerations of the site, as well as on consideration of power-plant components. Since the present analysis is not intended to be site specific, a value of 1.0 is used.

Each factor was used to multiply the base capital costs of the structure, handling equipment, and cooling towers. For the other power-plant components, it is assumed that basic design considerations would include dynamic loadings, which would withstand maximum expected seismic events.

\section{We1l Requirement}

The number of wells required at a given power-plant site depends on the individual flow rate per well, $\dot{m}$, and the total plant flow-rate demand, $\dot{M}$. Well replacement over the operating life of the plant is based on a model that assumes exponential resource depletion with a well half-1ife of 10 yr under maximum flow-rate conditions.

The number of wells required is

$$
\frac{\dot{M}}{\dot{m}}=n+\gamma \quad, \quad 0 \leq \gamma<1,
$$


where

$$
\begin{aligned}
& n=\text { integer number of wells, } \\
& \gamma=\text { partial well requirement. }
\end{aligned}
$$

Given the assumptions of the model, and if no resource replenishment is taken into account, the original plant flow-rate requirement would degrade exponentially as follows:

$$
\dot{M}(T)=\dot{M} e^{-\lambda t},
$$

where $\lambda=0.693 / \mathrm{T}_{1 / 2}$ and $\mathrm{T}_{1 / 2}$ is the well half-1ife under maximum flow conditions. Accordingly, to maintain the constant plant flow-rate demand level, $\dot{M}$, a flow rate increasing with time must be supplied by the remainder of the "partial well" originally at an excess level of $(1-\gamma)$. This flow increasing with time is given as

$$
\begin{aligned}
\dot{M}^{\prime}(t) & =\dot{M}-\dot{M}(t) \\
& =\dot{m}(n+\gamma)-\dot{m}(n+\gamma) e^{-\lambda t} \\
& =\dot{m}(n+\gamma)\left(1-e^{-\lambda t}\right)
\end{aligned}
$$

For the above inftial flow rate of the excess "partial we11," the mass resource remaining as a function of time is

$$
\begin{aligned}
M^{\prime}(t) & =(1-\gamma) \frac{\dot{m}}{\lambda}-\int_{0}^{t} \dot{M}^{\prime}(t) d t \\
& =(1-\gamma) \frac{\dot{m}}{\lambda}-\dot{m}(n+\gamma)\left[t-\frac{1}{\lambda}\left(1-e^{-\lambda t}\right)\right]
\end{aligned}
$$

Under maximum flow conditions for the "partial well," the initial time, $t_{1}$, at which the first new well must be brought into service is given when

$$
\dot{M}^{\prime}\left(t_{1}\right)=\lambda M^{\prime}\left(t_{1}\right)
$$

Substituting Eqs. (3) and (4) in relationship (5) and solving, the inftial replacement time obtained is 


$$
t_{1}=\frac{(1-\gamma)}{\lambda(n+\gamma)}
$$

After $t_{1}$, each additional time period, $\Delta t$, required to add (consecutively) new wells is determined in a manner similar to that given above. That is, maintaining the required plant flow-rate demand, $M$, the resource mass remaining in the new well as a function of a time period, $\Delta t$, measured from $t_{1}$, is

$$
\begin{aligned}
M^{\prime \prime}(t) & =\frac{\dot{m}}{\lambda} \int_{0}^{\Delta t} \dot{M}^{\prime}(t) d t \\
& =\frac{\dot{m}}{\lambda}-\dot{m}(n+\gamma)\left[t-\frac{1}{\lambda}\left(1-e^{-\lambda t}\right)\right] .
\end{aligned}
$$

Again, under maximum flow conditions for the new well, a second new well must be brought into service after the period $\Delta t$, when

$$
\dot{\mathrm{M}}^{\prime}(\Delta \mathrm{t})=\lambda \mathrm{M}^{\prime \prime}(\Delta \mathrm{t})
$$

Again, substituting Eqs. (3) and (6) in Eq. (7) and solving, the well replacement time period is

$$
\Delta t=\frac{1}{\lambda(n+\gamma)}
$$

Based on the above model, the number of wells required over the plant Iifetime, $N(y r)$, is

$$
N_{W}= \begin{cases}(n+1), & t_{1} \geq N \\ (n+1)+I\left(\frac{N-t_{1}}{\Delta t}\right), & t_{1}<N,\end{cases}
$$

where $I\left[\left(N-t_{1}\right) / \Delta t\right]$ designates "rounding up" to the next highest integer. The average annual number of resource wells is $\mathrm{N}_{\mathrm{W}} / \mathrm{N}$. Including reinjection wells, the average annual number of we11s, $\bar{N}_{W}$, is then $1.5\left(N_{W} / N\right)$. Multiplying $\bar{N}_{W}$ by the cost per well and the pipe factor gives the annual average cost of wells. 